\title{
ANÁLISE DO DESEMPENHO DO TENSIOMMETRO DE CÂMARA DE AR NA AVALIAÇĀO DO POTENCIAL MÁTRICO DA ÁGUA.
}

\author{
RAIMUNDO NONATO DE ASSIS JÚNIOR \\ Engenheiro Agrônomo
}

Orientador: Prof. Dr. Klaus Reichardt

Tese apresentada à Escola Superior de Agricultura "Luiz de Queiroz", da Universidade de Săo Paulo, para obtençåo do título de Doutor em Agronomia, Area de concentraçăo: Solos e Nutriçåo de Plantas.

\author{
PIRACICABA \\ Estado de São Paulo - Brasil \\ Outubro - 1995
}


Dados internacionais de Catalogação na Publicação (CIP) Divisão de Biblioteca e Documentação - CAMPUS "LUIZ DE QUEIROZ"/USP

Ass is Júnior, Raimundo Nonato de Anál ise do desempenho do tensiômetro de câmara de ar na avaliação

do potencial mátrico da água. Piracicaba, 1995.

$85 p$.

Tese - ESALQ

Bibliografia.

1. Água no solo 3. Tensiômetro 1. Escola Superior de Agricultura Luiz Luiz de Queiroz, Piracicaba 
ANÁLISE DO DESEMPENHO DO TENSIOMETRO DE CÂMARA DE AR NA AVALIAÇÃO DO POTENCIAL MÁTRICO DA ÁGUA.

RAIMUNDO NONATO DE ASSIS JÚNIOR

Aprovada em:11.12.95

Comissåo julgadora:

Prof. Dr. Klaus Reichardt

Prof. Dr. Nilson Augusto Villa Nova

Prof. Dr. Osny O. S. Bacchi

Dr. Júlio César Martins de Oliveira

Dr. Carlos M. P. Vaz
ESALQ/USP

ESALQIUSP

CENA/USP

UEL/Londrina

CNPDIA/EMBRAPA

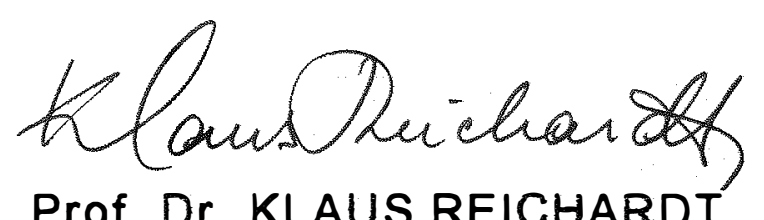

Prof. Dr. KLAUS REICHARDT

Orientador 
A Vânia, esposa e amiga, pelo incondicional e imprescindivel apoio, mormente nos momentos mais dificeis;

A Camila, pela sua beleza e capacidade de me fazer sorrir.

\section{DEDICO}

Ao Prof. Dr. Mardónio Aguiar Coelho (em memoria) que dedicou sua vida, com esforço e honestidade, ao ensino de física do solo. 
AGRADECIMENTOS

Ao Professor Klaus Reichardt, pelo apoio e orientação prestados durante a ralização deste trabalho, sem os quais as difuldades do percurso não teriam sido vencidas

Ao professor Nilson Augusto Villa Nova, pelas frutiferas discussões a respeito da teoria de funcionamento do instrumento, entre outras.

Aos Professores Paulo Leonel Libardi e Sérgio Oliveira Moraes, pela colaboração sempre presente.

Aos membros da comissão examinadora, pela revisão dos originais e sugestões apresentadas.

A Universidade Federal do Ceará, pelo afastamento concedido.

Ao Programa Institucional de Capacitação de Docentes (PICD/CAPES), pelo apoio financeiro na forma de bolsa de estudo.

Aos funcionários Francisco Bernardo Dias e Luiz Fernando Novello (ESALQIUSP) e José Ademir Rodrigues (CENA/USP), pela essencial colaboração prestada nas atividades realizadas em laboratório.

A todos que, de algum modo, colaboraram para a realização deste trabalho. 
SUMÁRIO

Página

LISTA DE FIGURAS ............................................ v

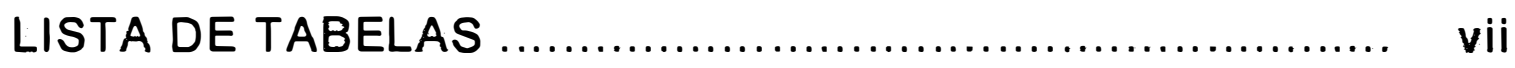

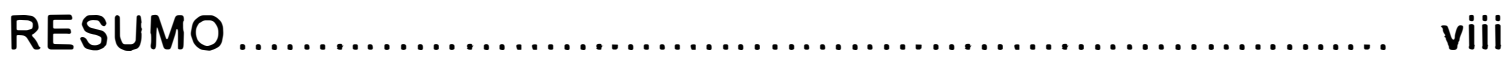

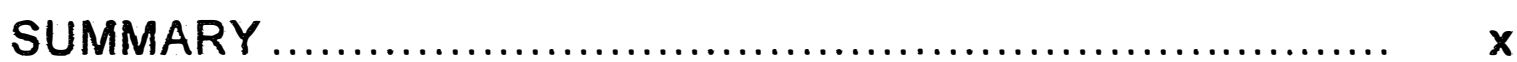

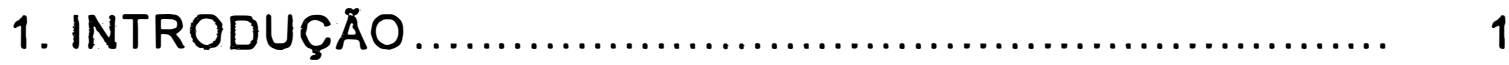

2. REVISĀO DE LITERATURA .................................... 3

2.1. O tensiômetro ........................................... 3

2.2. Uso do tensiômetro ........................................ 5

2.3. Variabilidade e tempo de resposta do tensiômetro... 11

2.4. Medidas do potencial da água com diferentes tipos de manômetros ............................................ 15

3. MATERIAL E MÉTODOS …................................. 23

3.1. Teste das cápsulas porosas ............................ 23

3.2. Confecção dos tensiômetros............................. 24

3.2.1. Tensiômetro com manômetro de mercúrio.... 24

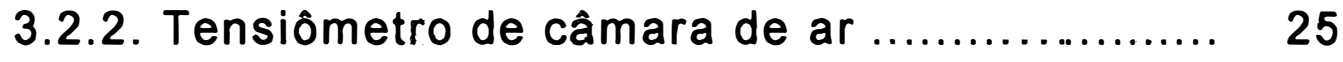

3.2.3. Tensiômetro com duplo manômetro ............. $\quad 25$

3.3. Condução dos experimentos ............................. 26

3.3.1. Experimento de laboratório com tensiômetro de duplo manômetro ............................... 26

3.3.2. Experimento de laboratório com tensiômetros de manômetros individuais...................... 27

3.3.3. Experimento de campo ........................... 28

3.4. Cálculo do potencial da água no solo .................. 31

3.4.1. Tensiômetro com manômetro de mercúrio.... 31

3.4.2. Tensiômetro de câmara de ar ................... 31 
4. RESULTADOS E DISCUSSÃO .............................. 36

4.1. Experimento de laboratório com tensiômetro de duplo manômetro....................................... 36

4.2. Experimento em laboratório com tensiômetros com manômetros individuais ............................... 41

4.3. Experimentos sob condições de campo .............. 45

4.3.1. Periodo seco ................................ 46

4.3.2. Periodo úmido ................................. 50

4.4. Influência da temperatura sobre o comportamento do tensiômetro com manômetro de câmara de ar.... 58

4.5. Sensibilidade do tensiômetro com manômetro de cåmara de ar ......................................... 61

4.6. Considerações finais................................. 64

5. CONCLUSO̊ES ............................................. 66

REFERENCIAS BIBLIOGRÁFICAS ......................... 67

APENDICES ..................................................... 75 


\section{LISTA DE FIGURAS}

Página

Figura 1 - Croqui de um bloco no experimento de campo ... 29

Figura 2 - Modelo esquemático do tensiômetro com manômetro de mercúrio .................................

Figura 3 -Modelo esquemático do tensiômetro com

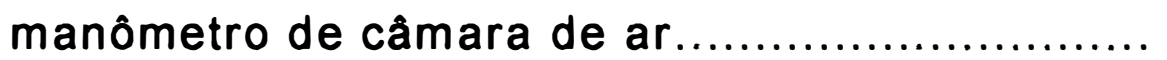

Figura 4 - Potencial mátrico versus tempo, tensiômetro de duplo manômetro, experimento de laboratório ....

Figura 5 -Relação entre potencial mátrico medido por tensiômetro de duplo manômetro (mercúrio e câmara de ar), no laboratório .......................

Figura 6 - Potencial mátrico versus tempo no experimento realizado no laboratório com tensiômetros com manômetros individuais

Figura 7 -Relação entre potencial mátrico obtido por tensiômetros com manômetros de mercúrio e de câmara de ar, experimento de laboratório ..........

Figura 8 - Evolução do potencial mátrico no tempo. $8 \mathrm{a}$ e $8 \mathrm{~b}$ correspondem às profundidades de 35 e $150 \mathrm{~cm}$, respectivamente, no bloco $\mathrm{I}$. $8 \mathrm{c}$ corresponde à

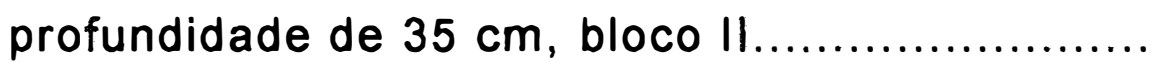

Figura 9 -Relação entre potencial mátrico obtido por tensiômetro convencional e de câmara de ar. Experimento de campo, periodo seco ...............

Figura 10 -Evolução do potencial mátrico no tempo para o experimento de campo, primeiro periodo úmido. 
Bloco I (a) $15 \mathrm{~cm}$; (b) $35 \mathrm{~cm} \mathrm{e} \mathrm{(c)} 150 \mathrm{~cm} \ldots \ldots . .51$ Figura 11 -Relação entre potencial mátrico obtido por tensiômetro convencional e de câmara de ar. Experimento de campo, primeiro periodo úmido 52

Figura 12 - Evolução do potencial mátrico no tempo no experimento de campo, segundo periodo úmido.

(a) bloco I, $15 \mathrm{~cm}$ e (b) bloco II, $15 \mathrm{~cm}^{`} \ldots \ldots \ldots$.

Figura 13 -Potencial mátrico com e sem correção da temperatura no experimento de campo, segundo periodo úmido. (a) bloco $1,15 \mathrm{~cm} \mathrm{e} \mathrm{(b)} \mathrm{bloco} \mathrm{II,}$ $15 \mathrm{~cm}$ 


\section{LISTA DE TABELAS}

Página

Tabela 1 - Valores de potencial mátrico obtidos no tensiômetro de duplo manômetro (mercúrio e e câmara de ar) no experimento de laborario....

Tabela 2 - Valores médios de potencial mátrico obtidos nos tensiômetros de mercúrio e de câmara de ar, no experimento de laboratório....................

Tabela 3 - Média, desvio padrão e coeficiente de variação dos valores de potencial mátrico obtidos por tensiômetros de mercúrio e de câmara de ar, bloco $1-15 \mathrm{~cm}$ de profundidade

Tabela 4 - Média, desvio padrão e coeficiente de variação dos valores de potencial mátrico obtidos por tensiômetros de mercúrio e de câmara de ar, bloco $11-15 \mathrm{~cm}$ de profundidade

Tabela 5 - Variação do potencial mátrico em função da variação na altura da câmara de ar................. 
ANÁLISE DO DESEMPENHO DO TENSIOMMTRO DE CÂMARA DE AR NA AVALIAÇÃO DO POTENCIAL MÁTRICO DA ÁGUA.

Autor: RAIMUNDO NONATO DE ASSIS JÜNIOR Orientador: PROF. DR. KLAUS REICHARDT

\section{RESUMO}

Foram feitos testes para avaliar o desempenho de tensiômetros com manômetro de câmara de ar, pela sua comparação com os resultados apresentados pelo tensiômetro convencional de manômetro de mercúrio. Dois testes foram feitos no laboratório de física do solo do Centro de Energia Nuclear na Agricultura - CENA/USP e um em condições de campo, realizado em uma terra roxa estruturada localizada na Escola Superior de Agricultura "Luiz de Queiroz" - ESALQIUSP, ambos em Piracicaba (SP).

O primeiro teste realizado no laboratório constou de um tensiômetro de duplo manômetro (mercúrio e câmara de ar), com a cápsula exposta às condições do ar ambiente. $O$ segundo foi feito com tensiômetros com manômetros individualizados, em vaso com solo homogêneo. No campo um experimento foi instalado, com delineamento de blocos ao acaso, com três profundidades e cinco repetiçōes, dentro de um seringal de 8 anos. Foi avaliada a resposta do tensiômetro de câmara de ar 
com relação a sua habilidade de monitorar a variação de potencial mátrico da água.

Os resultados mostraram que o tensiômetro de câmara de ar respondeu de forma semelhante ao tensiômetro com manômetro de mercúrio, embora com pequenas diferenças, as quais, porém, não invalidam o seu uso. A sensibilidade do manômetro de câmara de ar pode ser considerada como boa para uso em programas de irrigação. O efeito da temperatura sobre a resposta do tensiômetro de câmara de ar foi importante na faixa de alto potencial mátrico (solo úmido), porém não o foi para baixos potenciais (solo seco).

O uso do tensiômetro de câmara de ar pode ser recomendado para o monitoramento do potencial mátrico da água no solo nas condiçōes normais de cultivo, apresentando as vantagens de ser mais barato, mais fácil manuseio e não conter material tóxico. Para programas de pesquisa, no entanto, aconselha-se, ainda, o uso do tensiômetro de mercúrio, do qual as respostas já são mais conhecidas. 


\author{
PERFORMANCE ANALYSIS OF THE AIR-CAMBER \\ TENSIOMETER TO EVALUATE MATRIC WATER POTENTIAL.
}

\begin{abstract}
Author: RAIMUNDO NONATO DE ASSIS JÚNIOR Adviser: PROF. DR. KLAUS REICHARDT
\end{abstract}

\title{
SUMMARY
}

Tests were made to evaluate the performance of tensiometers with air chamber manometers, through the comparison with results of conventional mercury manometer tensiometers. Two tests were carried out in the soil physics laboratory of the Center for Nuclear Energy in Agriculture CENAIUSP, and a third one under field conditions, at the Escola Superior de Agricultura "Luiz de Queiroz" on a dark red latosol, locally called "terra roxa estruturada".

The first laboratory test was performed using a tensiometer with double manometers (mercury and air chamber), with the porous cup exposed to ambiental air conditions. The second test was performed with tensiometers having individual manometers, instaled in a pot of homogeneous soil. Under field conditions, a randomized block design was used, having three depths and five replicates, within a rubbertree crop, eight years old. 
Results indicated that the air chamber tensiometers had a similar response as compared to the mercury manometer tensiometers, althougt with small differences, which, however, do not invalidate their use. The sensivity of the air chamber tensiometer can be considered good for its use in irrigation programs. The temperature effect on the response of the air chamber tensiometer was important in the high range of matric potential (wet soil), but not for the low range (dry soil).

The use of the air chamber tensiometer can be recommended in field conditions to irrigation scheduling. For research programs, however, it is expected that the traditional mercury manometer tensiometer will still show a better performance. 


\section{INTRODUĢÃO}

O manejo adequado de um sistema de produção agricola é uma tarefa que requer conhecimento e controle de fatores ligados ao ambiente externo (atmosfera), à planta e ao solo. A complexidade desse sistema tripartite solo-plantaatmosfera tem estimulado pesquisadores a desenvolverem esforços no sentido de buscar desvendar seus meandros, de entender melhor suas relaçð̃es, a fim de manejá-lo mais racionalmente.

Dos fatores ligados ao solo, a água tem merecido grande atençăo, sendo que as condiçŏes em que ela se encontra no solo e sua disponibilidade para as plantas têm sido, já há bastante tempo, objetivos de estudos por parte daqueles que lidam com a ciência agronómica, no geral, e com a ciência do solo, em particular.

Ao longo do tempo, seguindo a evoluçăo da tecnologia, diversos instrumentos foram sendo criados com 0 objetivo de se detectar, de forma mais precisa e rápida, a quantidade e qualidade da água no solo em diponibilidade para as plantas. A criação desses instrumentos se deu concomitantemente com a evoluçăo nos conhecimentos teóricos e conceituais de disponibilidade de água às plantas. 
O conhecimento do "status" da água no solo revestese, portanto, de importåncia primordial, uma vez que permitenos um manejo correto desse fator de produçăo agricola em áreas irrigadas, isto é, faculta-nos a estimativa do momento e da quantidade de água que deve ser fornecida ao solo para a manutençăo do cultivo sob condiçőes hidricas adequadas, na busca da maximizaçăo da produtividade.

Dos vários instrumentos capazes de medir o estado energético da água no solo, sob condiçőes de campo, o tensiômetro tem sido um dos mais utilizados, por motivos tais como o de fornecer uma medida direta do potencial mátrico da água no solo, por apresentar baixo custo, facilidade de leitura, entre outros. O tensiômetro convencional, de uso mais comum, utiliza o mercúrio metálico como manómetro e isto tem sido visto como um problema do instrumento, uma vez que, associado ao uso do mercúrio, tem-se danos à saúde de quem - manuseia, risco de poluiçăo ambiental e dificuldade de manutençăo.

O objetivo do presente trabalho é testar o desempenho do tensiómetro de cåmara de ar em condiçőes de laboratório e de campo, na quantificaçăo do potencial mátrico da água no solo, pela comparaçăo de sua resposta com relaçăo àquela do tensiômetro convencional (manômetro de mercúrio). 


\section{REVISÃO DE LITERATURA}

\subsection{O tensiômetro}

O tensiômetro foi desenvolvido em 1922 por $W$. Gardner e colaboradores (BLACK, 1968). É um instrumento de campo utilizado para medir o potencial mátrico da água no solo, e consiste de uma cápsula porosa, geralmente de cerâmica, conectada a um manómetro através de um tubo completamente cheio de água (REICHARDT, 1985). A dimensão dos poros da cápsula é tal que, mesmo quando submetidas à uma pressăo de 1 atmosfera, esses poros năo săo esvaziados (REICHARDT, 1990).

O principio de funcionamento do tensiómetro é bastante simples. O instrumento é introduzido no solo, de tal modo que a cápsula de cerâmica porosa mantenha um contato o mais perfeito possivel com o solo, a fim diminuir o seu tempo de resposta. A água que se encontra no interior do instrumento, o qual deve estar hermeticamente fechado, entra em contato com a soluçăo presente no solo através dos poros da cápsula que săo permeáveis à água e năo ao ar, dentro de um certo limite de pressão - e um equilibrio tende a ocorrer dentro de um certo tempo. Na condiçăo inicial de fechamento do instrumento, 
a água dentro do tensiómetro está submetida à pressão atmosférica (considerada como estado padrăo de referência para o potencial mátrico, isto é, $\psi m=$ zero) e a água no solo năo saturado sob condiçőes subatmosféricas, provocando a saida de água do tensiómetro para o solo, até que a condiçăo de equilibrio seja alcançada (RICHARDS \& NEAL, 1936). Essa saida de água do tensiómetro provoca uma queda de pressăo em seu interior, a qual é registrada pelo manômetro. Essa pressăo subatmosférica medida no interior do instrumento na forma de energia potencial é, no equilibrio, igual à energia potencial (energia/volume) da água no solo. Daí, "qualquer mudança no conteúdo de água no solo, e conseqüentemente, em seu estado de energia, será transmitida à água no interior do instrumento, sendo indicada rapidamente pelo manómetro" (OLITTA, 1976).

A faixa de potencial mátrico da água no solo na qual se pode utilizar o tensiómetro é bastante estreita, variando de zero até aproximadamente 0,8 da pressăo atmosférica local. Segundo TAMARI et al. (1993), isso é causado pelo estado metaestável da água, quando essa se encontra sob tensão, a qual torna o liquido bastante instável, sendo que qualquer choque induzirá sua rápida vaporização. Essa faixa parece pequena, visto que, teoricamente, o limite inferior de potencial mátrico da água em que essa se encontra disponivel às plantas é de -1500kPa. PECK \& RABBIDGE (1966), descreveram um instrumento cujo principio de funcionamento assemelha-se ao tensiómetro, no qual polietileno glicol foi utilizado. O fluido era submetido a pressão e o potencial mátrico determinado através 
de transdutor de pressão. Para CAMPBELL (1987) isto estenderia consideravelmente a faixa de uso do instrumento, porém năo foi extensivamente usado, aparentemente por razőes práticas. Para REICHARDT (1990), mesmo com essa limitaçăo, o tensiômetro é um ótimo instrumento de campo para indicar quando irrigar, porque, para a maioria dos solos, maior quantidade de água é retida entre os potenciais de 0 e $-100 \mathrm{kPa}$ do que entre -100 e $-1500 \mathrm{kPa}$, mormente em solos arenosos. De fato ele tem sido extensivamente usado por permitir uma medida direta do "status" de energia da água contida no solo, sendo este estado energético da água que determina o seu movimento no solo e sua disponibilidade para as plantas.

As características externas do tensiómetro mudaram muito pouco com o passar do tempo (HOOK, 1987), embora algumas modificaçőes tenham permitido utilizá-lo numa faixa mais ampla de locais, tenham permitido a confiabilidade em suas respostas, simplificado as observaç⿸̃es e facilitado os procedimentos de instalaçăo e manuseio. Para esse autor, o tensiômetro permanece basicamente como concebido, uma ferramenta barata de pesquisa.

\subsection{Uso do tensiómetro}

Muitos pesquisadores, no Brasil e no mundo, têm utilizado o tensiômetro em seus trabalhos, com os mais variados fins para os quais o instrumento se presta, buscando calibrá-lo, melhorá-lo e/ou adequá-lo às sua necessidades. 
RICHARDS $\varepsilon$ NEAL (1936) utilizaram 0 tensiómetro para verificar mudanças na capacidade de retençăo de água pelo solo quando este foi submetido a diferentes tratamentos com matéria orgånica, observando, via leitura tensiométrica, diminuiçăo na tensăo da água nos poros capilares pela adiçăo de quantidades cada vez maiores de matéria orgânica. Previram, já naquela época, ser o tensiômetro um instrumento bastante útil em estudos de perdas de água do solo por evaporaçăo, de infiltraçăo e de conservaçăo de água no solo.

Para determinar o armazenamento da água no solo em disponibilidade às plantas, WERKHOVEN (1992) comparou os resultados de tensiômetros com os de TDR (Time Domain Reflectometry), concluindo que o tensiómetro é um instrumento plenamente adequado para tal objetivo.

Em agricultura irrigada, um dos problemas mais dificeis encontrados na prática é a decisăo do momento de irrigar, bem como a quantidade de água a ser aplicada em cada irrigaçăo. O tensiômetro tem sido utilizado na soluçăo desse problema. TAYLOR (1965) sugeriu um procedimento no qual usa-se dois tensiómetros, um dos quais instalado na profundidade de maior atividade do sistema radicular, e o outro um pouco mais abaixo das raizes. O tempo de irrigaçăo é determinado pelo tensiômetro mais raso, quando esse indica um aumento no potencial mátrico da água no solo para valores próximos à capacidade de campo ou maiores que esses. Se essa última condiçăo ocorre, é indicaçăo de que está havendo percolaçăo profunda; portanto, menor quantidade de água deve 
ser aplicada nas irrigaçøes subseqüentes. O exato valor do potencial mátrico da água no solo, o qual determina quando irrigar, não é o mesmo para todas as culturas. Porém, definido esse valor, a leitura do tensiômetro indicará o exato momento de se iniciar a irrigação. BEZERRA (1995) aplicou diferentes tratamentos de déficit hídrico na cultura da batata inglesa $e$ monitorou o potencial mátrico da água no solo através de tensiometria, fornecendo água ao solo sempre que o potencial mátrico atingia o valor de $-20 \mathrm{kPa}$. Estudos sobre o efeito do potencial mátrico da água no solo sobre a produção de quatro culturas foram feitos por TAYLOR (1952) utilizando tensiômetros na faixa de tensão da água no solo entre 0 e $-70 \mathrm{kPa}$.

POOLEY (1973) mostrou que, com o uso do tensiómetro, pode-se determinar com mais eficiência os intervalos de irrigação e que, em seu experimento, isto representou uma economia de $15 \%$ no custo total das operaçőes com o cultivo, além de proporcionar maior produção e melhor qualidade dos produtos. Economia de água e de energia também foi observada por SMAJSTRLA \& KOO (1986) em programa de irrigação por gotejamento em laranja, utilizando o potencial mátrico da água no solo, medido por tensiómetro, como indicador do momento de irrigar e da quantidade de água a ser aplicada em cada irrigação.

SMAJSTRLA \& LOCASCIO (1990) compararam resultados da irrigação baseada em dados tensiométricos e em tanque de evaporação classe $A$ na produção e requerimento de 
irrigaçăo em tomate irrigado por gotejamento. A aplicaçăo de água foi reduzida quando a irrigaçăo foi baseada nos valores de potencial mátrico, quando comparada com a irrigação baseada no tanque classe $A$. Nenhuma diferença significativa foi observada na produção de tomate pelos dois sistemas, porém, a economia de água e de energia sugeriu o uso do tensiômetro no controle da irrigaçăo.

O controle do potencial mátrico da água no solo em quatro tratamentos de irrigaçăo por gotejamento em algodăo foi feito por WIERENGA et al. (1987) com tensiômetros. Também ai 0 instrumento mostrou-se muito eficiente no controle da irrigação e economia de água, proporcionando um manejo mais adequado da água e um aumento na produção da cultura.

HODNETT et al. (1990) compararam métodos de controle de irrigaçăo utilizando indice tensiométrico e valores estimados de evapotranspiraçăo potencial em cana-de-açúcar e obtiveram maior produçåo quando o controle foi feito baseado em indice tensiométrico, utilizando um potencial mátrico de -80kPa; além disso, concluíram, esse é um método de operaçăo mais simples e nåo requer nenhuma outra coleta de dados a năo ser as leituras dos tensiómetros

A necessidade de programas de irrigação, mesmo em regiðes úmidas, foi apontada por LAMBERT et al. (1981), principalmente para agricultura intensiva; eles sugeriram que o controle da necessidade de irrigaçăo deve ser feito por tensiometria e os seus resultados indicaram que o potencial mátrico da água no solo mantido acima de $-20 \mathrm{kPa}$ nos $60 \mathrm{~cm}$ superficiais do solo proporcionou maiores produções. 
Estudos objetivando investigar a adequabilidade de se basear a irrigaçăo no potencial mátrico da água no solo, em comparação com o método tradicional de turno de rega com tempo estabelecido, foram feitos por AUGUSTIN \& SNYDER (1984). Eles investigaram, também, a influência da irrigaçăo sobre a adubaçăo do solo com nitrogênio e observaram que, durante o verăo chuvoso, onde a necessidade de irrigaçăo é menor, o método baseado no potencial mátrico foi mais efetivo, eliminando irrigaçðes desnecessárias. Por um período de 3 anos - 1980 a 1982 - a quantidade de irrigaçăo por esse procedimento foi $42 \%$ menor. No periodo seco o resultado foi semelhante, com um número de irrigaçăo $47 \%$ menor. A interaçăo entre a forma de irrigaçăo e fonte de nitrogénio foi observada apenas no periodo seco. Nesse periodo, a irrigaçăo por turno de rega aumentou a velocidade de liberação de nitrogênio, em relaçăo à irrigaçăo baseada em leituras tensiométricas. Estatisticamente, porém, o fornecimento de nitrogênio às plantas foi igual am ambos os casos. Assim, o procedimento baseado nas leituras tensiométricas mostrou-se eficiente na reduçăo dos custos de irrigação e de nitrogênio.

$O$ tensiômetro tem sido utilizado principalmente para aplicaçōes agricolas, através do monitoramento do potencial mátrico da água no solo. Uma dupla utilizaçăo do instrumento foi feita por MORRISON \& SZECSODY (1987), onde o aparelho serviu como amostrador (coletor) de água e como indicador do potencial mátrico. Feitas as medidas do potencial, o fluido era retirado do tensiômetro, aplicava-se um vácuo e coletava-se uma amostra da água para monitoramento de 
contaminantes. Evidentemente, modificações no instrumento foram necessárias para permitir esse duplo uso, tal como o uso de uma válvula de via dupla, a qual permite tal utilização do instrumento. Uso semelhante do instrumento foi feito por TOKUNAGA (1992).

DEXTER (1990) estudou o rearranjamento das partículas do solo usando valores de potencial mátrico, medidos com tensiómetro. Amostras de solo foram destorroadas, umedecidas e colocadas em vasos hermeticamentes fechados, nos quais estavam instalados os tensiómetros. A umidade foi mantida constante com o tempo e medidas tensiométricas foram feitas. As variaçőes nos valores de potencial com o tempo foram entendidas como modificações no arranjamento das particulas, principalmente das argilas. Essas observaçōes săo consistentes com a idéia de que as partículas de argila săo orientadas de modo paralelo umas às outras após a moldagem e, subseqüentemente, se orientam em arranjamento bordo-face ou bordo-bordo.

Outro uso bastante comum do tensiómetro é feito na verificação do fluxo de água no solo em condiçăo de não saturação. BOOLTINK \& BOUMA (1991) estudaram o fluxo de água em uma coluna de solo em laboratório, onde os potenciais em profundidade foram determinados com o uso de pequenos tensiómetros, concluindo que o fluxo de água no solo é muito mais complexo do que sugerido pela literatura corrente, que $o$ arranjamento das partículas do solo deve ser considerado quando se deseja caracterizar o fluxo, que a continuidade dos macroporos governam o fenômeno e que o uso de tensiômetros 
é essencial para se expressar esses processos em termos quantitativos. Em estudos de fluxos intermitentes (năo contínuo) como esse, uma atenção especial deve ser dada à interpretaçăo dos resultados obtidos, uma vez que eles podem incorporar tanto as mudanças de pressăo hidrostáticas quanto a pressăo do ar enclausurado contra a parede da cápsula porosa (WATSON, 1967).

O fluxo de água de percolação é muito importante em irrigação e em estudos de lixiviação, principalmente em solos com problemas de salinidade. SINGH et al. (1988) compararam o fluxo de água no solo por medidas tensiométricas e por medidas diretas feitas com lisimetro. $O$ resultado mostrou excelente correlação entre os dois métodos, mostrando que a percolação da água no solo pode ser prenunciada por técnica tensiométrica.

\subsection{Variabilidade e tempo de resposta do tensiómetro}

O tempo de resposta do instrumento, entendido como o tempo necessário para o equilibrio de energia da água no tensiómetro com a água no solo, foi estudado por KLUTE $\varepsilon$ GARDNER (1962). Para eles, a resposta do tensiómetro às mudanças de de potencial mátrico da água no solo é dependente da sensibilidade do medidor (manómetro), da condutância hidráulica da cápsula porosa e da condutividade hidráulica do solo no qual 0 instrumento está instalado. Portanto, caracteristicas relacionadas ao aparelho $e$ relacionadas ao solo estão envolvidas no controle do tempo de 
resposta do instrumento. Esses pesquisadores fizeram uma análise matemática dos aspectos envolvidos no processo e mostraram ser possível o cálculo do tempo de resposta do tensiômetro, concluindo que esse tempo é maior quando o fator limitante é a condutividade hidráulica do solo do que quando os fatores limitantes sâo aqueles relacionados ao instrumento. Estudos detalhados sobre esses aspectos também foram feitos por TOWNER (1980).

VILLAGRA et al. (1988) correlacionaram dados de tensiometria e variabilidade espacial do solo; investigaram a variabilidade das leituras relativas ao instrumento e, também, tempo de resposta. Os resultados para tempo de resposta do instrumento foram semelhantes aos encontrados por KLUTE $\varepsilon$ GARDNER (1962), isto é, maior é o tempo necessário para atingir 0 equilibrio quanto menor for 0 potencial. Para VILLAGRA et al. (1988) o tempo de 8 horas foi suficiente para que 0 potencial mátrico da água no tensiómetro passasse de 0 (após a fluxagem) para $-50 \mathrm{kPa}$.

Para verificar o tempo de resposta de um sistema portátil tensiómetro/transdutor, MULLINS et al. (1986) instalaram um experimento no qual utilizaram tensiômetros com manómetro de mercúrio e com medidor de vácuo do tipo Bourdon. Os tensiómetros foram instalados em caixas de metal, no laboratório. No momento de cada leitura, tensiômetros portáteis com transdutores acoplados eram introduzidos no solo às mesmas profundidades dos tensiómetros já instalados e as leituras eram feitas. As medidas eram feitas até que os valores de potencial dos tensiómetros portáteis fossem equivalentes 
àqueles dos tensiómetros previamente instalados. Os resultados mostraram que o tempo para que isso ocorresse variou de alguns minutos para potenciais maiores que $-5 \mathrm{kPa}$ até mais de duas horas para potenciais menores que -30kPa. Do ponto de vista prático isso significa que o tensiómetro portátil apresenta leituras confiáveis apenas quando o solo se encontra bastante úmido. A inserção do tensiômetro no solo provoca, em maior ou menor magnitude, uma deformaçăo do solo circundante da cápsula, de modo que algum tempo é necessário para que haja um equilíbrio da água dessa regiăo com aquela da zona năo perturbada do solo.

Um aumento na velocidade de resposta do tensiómetro pode ser conseguida pelo uso de transdutores de pressåo (KLUTE \& PETERS, 1962; RICE, 1969). Isso é essencial quando as variaçర̃es na pressão da água no solo ocorrem muito rapidamente, como durante a infiltração da água no solo ou durante a evapotranspiraçăo. Contudo, TOWNER (1982), afirma que o tempo de resposta é marcadamente influenciado pelo tensiómetro em si, ou seja, pelo tempo necessário para que a pressão no tensiómetro entre em equilibrio com a pressåo no transdutor. Para o autor, em condiçőes de campo, a resposta năo é tăo rápida como a que se tem conseguido com as medidas com transdutores em água livre.

Estimativas confiáveis do potencal mátrico da água no solo usando poucos tensiômetros săo dificeis de serem obtidas por causa da grande variabilidade espacial dessa propriedade do solo, de modo que muitas medidas devem ser 
tomadas para se ter uma média aceitável. Por outro lado, monitorar o potencial mátrico da água em numerosos locais dentro de um campo năo é factível, devido a limitações económicas e práticas.

A variabilidade espacial do solo foi considerada como importante fator a ser considerado quanto se utiliza tensiómetro para medir o potencial da água no solo (VILLAGRA et al., 1988), uma vez que a variância total dos valores de potencial foi devida muito mais à variabilidade do solo do que do instrumento.

Resultados semelhantes foram observados por HENDRICKX \& WIERENGA (1990) em experimento com pimenta sob regime de irrigaçăo por gotejamento. Numa área de $0,15 \mathrm{ha}$ recebendo o mesmo volume de água eles observaram variações nos valores de potencial mátrico, as quais foram atribuidas à variabilidade espacial do solo. Eles verificaram também que a variância nas leituras do tensiômetro foi maior quando o solo estava seco.

A variabilidade nos valores de potencial mátrico medidos com tensiómetros pode estar associada também ao momento da leitura. THOMAS $\varepsilon$ PHILLIPS (1991) fizeram medidas tensiométricas antes, imediatamente após, 30 minutos após e 24 horas após uma irrigaçăo de $50 \mathrm{~mm}$ aplicada em 90 minutos. As leituras feitas antes e 24 horas após a irrigaçăo apresentaram-se estáveis. As leituras feitas imediatamente após e 30 minutos após a irrigaçăo foram variáveis. À mesma profundidade, encontrou-se valores de potencial desde negativos até positivos. Foram coletadas amostras de solo e 
essas mostraram que $13,5 \mathrm{~mm}$ de água, do total de $50 \mathrm{~mm}$ aplicados, estavam no solo em seus $60 \mathrm{~cm}$ iniciais logo após a irrigação e que, 24 horas após a irrigação, toda a água aplicada já havia drenado para profundidades além de $60 \mathrm{~cm}$.

HENDRICKX et al. (1994) avaliaram o efeito do tamanho da cápsula porosa do tensiômetro sobre a variabilidade dos valores de potencial mátrico medidos, utilizando três diferentes tamanhos de cápsula, denominadas pequenas, médias e grandes $\left(4.8,42.3\right.$ e $88.3 \mathrm{~cm}^{2}$ de área superficial externa, respectivamente). O aumento no tamanho da cápsula reduziu a variabilidade nos valores de potencial, sugerindo que a cápsula de tamanho médio, extensivamente usada na maioria dos programas de irrigaçăo, ainda é muito pequena, causando variabilidade relativamente alta, devendo ser substituida por cápsulas de tamanhos maiores.

\subsection{Medidas do potencial mátrico da água com diferentes tipos de manômetros}

A facilidade de instalação e a habilidade de fornecer uma medida direta do "status" da água no solo tornaram o tensiőmetro um instrumento muito útil no monitoramento da água no solo, em condiçőes de campo (MARTHALER et al., 1983). No entanto, apesar dessas vantagens, o seu uso em programas de irrigaçăo năo tem sido tão intenso quanto o que deveria ser esperado. Uma das razóes para isso é o custo dos tensiómetros equipados com medidores de pressão do tipo Bourdon, que, quando usado em grande 
quantidade, é alto; além disso, esse tipo de medidor de pressão danifica-se com facilidade e requer cuidadosa manutenção. Tensiômetros equipados com manômetros de mercúrio, por outro lado, são baratos e sensiveis, mas requerem considerável manutenção em condições de campo e apresentam problemas relacionados à saúde e riscos de poluição ambiental. Isso tem conduzido os pesquisadores a tentarem formas outras de determinar o potencial mátrico da água no solo utilizando o tensiómetro associado a outros medidores de pressão elou tensão.

Sistemas tensiômetro/transdutor de pressão têm sido utilizados para medir a pressão da água nos poros do solo e a distribuição do gradiente hidráulico tanto em campo como em laboratório.

Um transdutor elétrico de pressão foi construido por THIEL et al. (1963) para medir pressōes hidrostáticas em meio poroso. O principio de funcionamento do transdutor foi centralizado na deflexāo de um diafragma circular de aço inoxidável em função das pressões aplicadas. Uma equação foi desenvolvida para relacionar a pressão da água com as propriedades geométricas e condiçð̌es de pressão do diafragma. Um transformador diferencial linearmente variável foi usado como sensor da deflexão do diafragma. Conhecendose a magnitude de uma unidade de deflexảo e a faixa total a ser medida, um sensor elétrico é utilizado como indicador. O transdutor deve ser calibrado antes da instalação. A curva de calibração é feita plotando-se a saida elétrica (volts) versus pressão aplicada. 
MARTHALER et al. (1983) construiram e utilizaram um sistema tensiómetro/transdutor, o qual consistia de um transdutor de pressão conectado ao tensiómetro através de uma agulha de seringa, tendo um registrador digital. A agulha era introduzida através de uma tampa de borracha presente na extremidade superior do tensiómetro. A pressăo do ar numa pequena câmara deixada abaixo da tampa de borracha equilibrava-se com a pressão na água no tensiômetro, sendo mostrada no registrador digital. Para os autores, o uso desse tipo de transdutor permite uma manutençăo mais rápida e mais fácil do instrumento do que quando se usa manómetro de mercúrio, além de diminuir a influência da temperatura e a chance de danos mecánicos.

NYHAN \& DRENNON (1990) utilizaram transdutores de pressão e um sistema computadorizado de obtenção de dados acoplado ao tensiómetro para automatizar a medida do potencial mátrico aumentando, assim, a velocidade de tomadas de leituras, possibilitando se fazer medidas em intervalo de tempo mais curto com maior eficiência no manuseio e na análise dos dados.

A medida do potencial mátrico da água no solo com tensiómetros foi efetuada por LONG (1984), utilizando transdutores de vácuo nos quais as leituras de voltagem de saida relacionavam-se linearmente com a tensão da água no interior do tensiómetro. Além disso, um processador de dados, acoplado ao sistema, foi programado para esquadrinhar os transdutores a intervalos selecionados e registrar as informaçōes em fita cassete. As informaçőes eram, 
posteriormente, transferidas para um computador para cálculo e plotagem do potencial mátrico versus tempo. Esse sistema tem a vantagem de permitir que várias leituras possam ser feitas por dia em um número grande de tensiómetros, essencial em estudos do movimento da água no solo. O sistema mostrou-se adequado para o uso sob condições de campo.

Para LONG (1982), o transdutor de pressão é capaz de fazer medidas da pressão dentro do tensiómetro com uma exatidåo suficiente para tornar o manómetro de mercúrio obsoleto. O modelo de transdutor testado por ele permitiu leituras em milivolts, fornecendo assim leitura de pressăo com uma precisăo equivalente a $0,2 \mathrm{~cm}$ de água. Sensibilidade semelhante já havia sido observada por KLUTE \& PETERS (1962), os quais conseguiram detectar variaçăo na pressăo da água da ordem de 0,2 a $0,3 \mathrm{~cm}$ de água. No entanto, TROTTER (1984) considera temerosa a recomendação de uso do transdutor baseada apenas na precisão de saida de voltagem do instrumento, pois essa pode variar com o tempo, temperatura, estimulo de voltagem e pela pressåo aplicada.

GAUSSOIN et al. (1990) compararam o desempenho de tensiómetros com manômetros de mercúrio com sistema tensiômetro/transdutor de pressăo em solo cultivado com grama, no qual os tensiómetros foram instalados superficialmente, entre 5 e $10 \mathrm{~cm}$ de profundidade, encontrando uma relaçăo linear entre os resultados, com coeficiente de determinação da ordem de 0,97 , mostrando a a adequabilidade do uso de transdutores. 
Como mostrado no trabalho de MARTHALER et al. (1983) o sistema tensiômetro/transdutor de pressăo tem a caracteristica de diminuir o efeito da temperatura sobre as medidas. Os resultados obtidos por NYHAN \& DRENNON (1990) também se mostraram independentes das condiçōes de pressăo atmosférica e de variaçåo na temperatura do ambiente, enquanto que um declínio lento, porém constante, na pressăo com o aumento na temperatura de 0 a $50{ }^{\circ} \mathrm{C}$ foi observado por Van Der ELSEN \& BAKKER (1992).

Para LOWERY et al. (1986), o uso inicial de transdutores de pressåo limitou-se a estudos de laboratório devido a problemas de temperatura, custos e materiais elétricos associados. Eles conduziram um experimento em campo para testar o efeito da temperatura sobre os valores de potencial mátrico com transdutores de pressăo e observaram que pouco efeito foi evidenciado sobre os resultados com flutuaçōes de temperatura de 10 a $30^{\circ} \mathrm{C}$, mantendo-se o potencial constante. Tensiómetros do tipo Bourdon foram utilizados para efeito de comparaçăo dos resultados durante 29 dias e nenhuma diferença significativa foi observada entre os potenciais determinados pelo tensiômetro de Bourdon e pelo transdutor de pressåo.

NYHAN et al. (1987) encontraram variaçðes nos valores de potencial mátrico obtidos com tensiômetros acoplados a transdutores de pressåo e tensiômetros convencionais, sob condiçóes de campo, quando comparados com os resultados obtidos pelos mesmos instrumentos sob condições de temperatura controlada. As variações nos valores 
de potencial acompanharam as variações diárias de temperatura, sendo que essas variaçőes foram maiores nas profundidades de 30 e $60 \mathrm{~cm}$ do que na profundidade de $220 \mathrm{~cm}$. Como se sabe, a amplitude de variação da temperatura no solo é maior em profundidades menores.

Transdutores de pressão em conjunçăo com tensiômetros e tensiômetros do tipo Bourdon foram testados sob pressōes constantes de $0,-25,-50$ e $-75 \mathrm{kPa}$ e temperaturas de $5,15,25$ e $48{ }^{\circ} \mathrm{C}$ em cámara controlada (AZOOZ \& ARSHAD, 1994). As leituras foram tomadas em $\mathrm{mV}$ no sistema tensiómetro/transdutor e em $\mathrm{kPa}$ no tensiômetro de Bourdon. Houve declínio gradual nas leituras dos dois sistemas com o aumento da temperatura, exceto no tensiômetro de Bourdon à pressão constante de $0 \mathrm{kPa}$, visto que, nesse caso, nenhum vácuo foi criado dentro do tensiómetro. Para os autores, isso significa que, para apresentarem resultados corretos, esses sistemas devem ser ajustados à temperatura sob a qual eles serão usados.

Em experimento de laboratório WATSON $\varepsilon$ JACKSON (1967) utilizaram um sistema tensiómetro/transdutor e observaram que o mesmo foi sensivel às variações na temperatura ambiente, pois essas flutuações provocaram variação na pressão registrada pelo transdutor.

O uso de transdutor portátil para ser acoplado ao tensiómetro no momento da leitura foi examinado por CRESSWELL (1993). Ele observou que a conecção do transdutor ao tensiómetro via agulha de seringa introduzida na tampa de borracha do instrumento provocou mudanças na 
pressão no seu interior, de tal forma que um tempo de até 120 minutos foi necessário para que o reequilíbrio com a pressão original (antes da introdução da agulha) fosse atingido. Como em resultados já anteriormente observados, esse tempo foi maior para potenciais menores. Ele observou ainda que esse tempo é menor com o aumento no tamanho da câmara de ar deixada no interior do tensiómetro. Para efeito prático, o autor sugeriu que as leituras fossem feitas no momento da conecção do transdutor e, posteriormente, se fazer a correção através de curvas padrões de reequilibrio previamente determinadas.

Desde 0 advento do tensiómetro, admite-se que seu funcionamento só é perfeito se ele for mantido absolutamente cheio de água, sem a presença de ar. Por isso foi sempre recomendado 0 uso de água fervida nos tensiômetros. CAMARGo et al. (1982), através de observações em tensiômetros transparentes verificaram que, mesmo com o uso de água fervida, havia a formação de câmara gasosa no alto da coluna do liquido, que crescia com o aumento das tensões acusadas pelo manómetro. Quando o tensiômetro era fluxado, na tentativa de eliminar a câmara gasosa, essa se refazia em poucos dias. Essa câmara sugeriu a possibilidade de se estimar a tensão no sistema baseando-se simplesmente na altura da mesma. Nesse trabalho, CAMARGO et al. (1982) mediram o potencial da água no solo através do manômetro de mercúrio ao mesmo tempo em que liam a altura da câmara de ar que se formava, encontrando uma relação hiperbólica entre a altura da câmara de ar e o potencial mátrico, concluindo haver possibilidade de uso desse tensiômetro, dispensando-se o uso do mercúrio metálico. 
Uma análise teórica do tensiómetro de cåmara de ar foi feita por VILLA NOVA et al. (1989), na qual foram consideradas variáveis climáticas que influenciam a resposta do instrumento. Os autores propuseram um modelo matemático para o cálculo do potencial mátrico a partir da altura da câmara no momento da leitura, levando-se em conta a câmara inicialmente deixada no tensiómetro.

VILLA NOVA et al. (1992), fizeram estudos comparativos entre tensiómetro de câmara de ar e de manómetro de mercúrio em dois tipos diferentes de solos, no laboratório, usando câmara inicial de $3,0 \mathrm{~cm}$. Observaram equivalência entre os resultados dos dois tipos de tensiómetro e recomendaram o uso do tensiómetro de leitura direta para programas de irrigaçăo, devido a sua simplicidade e baixo custo.

Testes com tensiómetros de cåmara de ar foram feitos por TOKUNAGA $\varepsilon$ SALVE (1994), os quais apontaram como vantagens desse tipo de tensiômetro a possibilidade de poder fazer medidas tensiométricas a potenciais inferiores a $-90 \mathrm{kPa}$ (valor frequentemente associado ao limite de funcionamento do tensiómetro convencional), facilidade de leitura e baixo custo. 


\section{MATERIAL E MÉTODOS}

\subsection{Teste das cápsulas porosas}

As cápsulas porosas utilizadas na confecção dos tensiómetros foram testadas quanto à pressăo de borbulhamento e condutância hidráulica. O primeiro teste objetivou eliminar cápsulas danificadas, nas quais o borbulhamento de ar ocorreu a pressőes inferiores a 1 atmosfera, aproximadamente a pressão máxima de funcionamento do instrumento. O segundo teste teve como objetivo a uniformizaçăo das cápsulas, a fim de que o tempo de resposta dos tensiómetros fosse o mais semelhante possivel.

Para o teste de pressão de borbulhamento as cápsulas foram previamente saturadas com água $e$, posteriormente, conectadas a um sistema de pressão. Foram então submetidas à pressão de 1 atm., sendo considerada adequadas para uso aquelas que suportaram tal pressão, ou seja, aquelas que não permitiram a passagem de ar pelos seus poros quando submetidas a essa pressão.

$\mathrm{Na}$ verificação da condutância hidráulica foi utilizado o método de carga decrescente, o qual consiste na determinação do tempo necessário para que uma coluna de água que atua sobre a cápsula caia de alturas previamente 
determinadas, observada em tubo transparente. A condutåncia hidráulica é calculada pela equaçăo:

$$
\kappa=a \cdot \ln \left(H_{1} / H_{2}\right) / T_{2}-T_{1}
$$

$$
\begin{aligned}
& \text { onde: } \quad k=\text { condutåncia hidráulica }\left(\mathrm{cm}^{2} / \mathrm{s}\right) \\
& a=\text { área da secçăo transversal do tubo }\left(\mathrm{cm}^{2}\right) \\
& H_{1} \text { e } H_{2}=\text { Alturas da coluna de água, ou seja, } \\
& \text { potenciais totais }\left(\mathrm{cm} \mathrm{H} \mathrm{H}_{2} \mathrm{O}\right) \text { nos tempos } \mathrm{T}_{1} \mathrm{e} \\
& T_{2} \text {, respectivamente. } \\
& T_{1} \text { e } T_{2}=\text { intervalo de tempo que a coluna de água no } \\
& \text { tubo leva para cair de } \mathrm{H}_{1} \text { para } \mathrm{H}_{2} \text {. }
\end{aligned}
$$

\subsection{Confecçăo dos tensiômetros}

\subsubsection{Tensiómetro com manómetro de mercúrio}

Os tensiômetros com manômetro de mercúrio foram construidos utilizando-se tubos de PVC, com diâmetro interno de $3 / 4$ de polegada $(1,905 \mathrm{~cm})$. Numa extremidade do tubo fez-se a colagem da cápsula, utilizando-se cola araldite. Próximo à extremidade oposta à que se colou a cápsula foi feito um furo para a introduçăo do "espaguete" de plástico flexivel de $0,2 \mathrm{~cm}$ de diåmetro interno, o qual interliga o sistema tubo/cápsula ao depósito de mercúrio. O "espaquete" foi colado ao tubo de PVC para evitar a entrada de ar no sistema. A extremidade oposta a cápsula foi vedada por tampa removível, com rosca e junta de borracha do tipo "o-ring". 
Para uso nos experimentos de laboratório os tensiómetros construidos apresentavam o mesmo tamanho, enquanto que para o experimento de campo os tensiómetros apresentavam tamanhos variados, em função das três profundidades de instalação $(15,35$ e $150 \mathrm{~cm})$.

\subsubsection{Tensiômetro de câmara de ar}

Os tensiômetros de câmara de ar foram construidos de forma idêntica àquela do tensiômetro com manômetro de mercúrio, com duas modificações: (a) ausência do "espaguete", e (b) na extremidade oposta à cápsula porosa foi conectado um tubo de plástico transparente com diâmetro interno de $3 / 8$ de polegada $(0,952 \mathrm{~cm})$, de $50 \mathrm{~cm}$ de comprimento, no qual se pode facilmente fixar uma altura inicial da câmara de ar e se verificar as modificações na altura da câmara, causada pela saida de água do instrumento para o solo. A vedação da extremidade desse tubo transparente foi feita, como no caso anterior, com tampa removivel, com rosca e junta de borracha do tipo "o-ring".

\subsubsection{Tensiômetro com duplo manômetro}

Com o objetivo de se verificar a resposta dos dois tipos de manômetros a um único estímulo exercido sobre a cápsula porosa, foi construido um tensiômetro de duplo manômetro. Este foi construido juntando-se os procedimentos 
de construção dos dois anteriores. O tamanho total desse tensiómetro foi de $84,3 \mathrm{~cm}$.

\subsection{Condução dos experimentos}

\subsubsection{Experimento de laboratório com tensiômetro de duplo manômetro}

Este experimento foi conduzido no laboratório de Fisica do Solo do Centro de Energia Nuclear na Agricultura da Universidade de Săo Paulo - CENA/USP.

O tensiómetro foi colocado sobre um balcão, fixado verticalmete por um suporte de ferro. A cápsula ficou exposta ao ar, perdendo água por evaporação, de acordo com as condições ambientais. A cubeta de mercúrio foi fixada a um suporte de ferro, a $62 \mathrm{~cm}$ do centro da cápsula porosa. A câmara inicial utilizada tensiómetro de de câmara de ar foi de $3 \mathrm{~cm}$. Após a completa saturação dos poros da cápsula com água foram iniciadas as leituras.

Várias séries de leituras foram tomadas nos dois manómetros. As leituras foram feitas de hora em hora durante o dia. Utilizou-se régua com precisão de $1 \mathrm{~mm}$ para medir tanto a altura da coluna de mercúrio quanto a altura da câmara de ar. No final de cada tarde uma série era concluida e a cápsula porosa do tensiómetro era imersa em água, retornando-se à condição inicial e, no dia seguinte, uma nova série era iniciada. Algumas vezes a série năo foi concluida ao final da tarde e as leituras tomadas no dia seguinte eram consideradas na série do dia anterior. 


\subsubsection{Experimento de laboratório com tensiómetros de manômetros individuais}

Este experimento foi conduzido no laboratório de Física do Solo do Centro de Energia Nuclear na Agricultura da Universidade de São Paulo - CENA/USP, com o objetivo de se verificar o comportamento do tensiômetro de leitura direta em comparação com aquele do tensiómetro convencional com manômetro de mercúrio, sob condições controladas de temperatura e em solo homogêneo.

Os tensiômetros de mercúrio e de câmara de ar foram instalados a $8 \mathrm{~cm}$ de profundidade, com 5 repetições, em fila indiana, alternados e distanciados de $5 \mathrm{~cm}$ um do outro, num total de 10 tensiómetros. O solo utilizado foi uma Terra Roxa Estruturada do campus da Escola Superior de Agricultura "Luiz de Queiroz" da Universidade de São Paulo - ESALQ/USP. A amostra de solo foi coletada, seca ao ar, destorroada e tamizada em malha de

$2 \mathrm{~mm}$ de diåmetro. O material do solo, com diåmetro menor que $2 \mathrm{~mm}$, foi colocado em vaso de cimento de $10 \mathrm{~cm}$ de largura, $110 \mathrm{~cm}$ de comprimento e $15 \mathrm{~cm}$ de profundidade. Os tensiômetros de leitura direta tinham $84 \mathrm{~cm}$ de comprimento. Nos tensiômetros de manômetro de mercúrio a distância entre 0 reservatório de mercúrio e o centro da cápsula foi de $48 \mathrm{~cm}$.

Após a instalação dos tensiómetros o solo foi umedecido. Os tensiómetros foram fluxados, iniciando-se as leituras. Várias séries de leituras foram feitas; em algumas 
delas as leituras foram feitas a cada hora. Em outras, as leituras foram feitas diariamente. Quando o potencial mátrico do solo atingia valores próximos a $-85 \mathrm{kPa}$ era feito 0 reumedecimento do solo, iniciando-se uma nova série de leituras.

\subsubsection{Experimento de campo}

Um experimento de campo foi conduzido no campus da Escola Superior de Agricultura "Luiz de Queiroz" da Universidade de Săo Paulo - ESALQ/USP, na cidade de Piracicaba, SP. Piracicaba situa-se nas coordenadas geográficas de $22^{\circ} 42^{\prime}$ de latitude sul e $47^{\circ} 38^{\prime}$ de longitude oeste e altitude de $540 \mathrm{~m}$. O clima da região, na classificação climática de Köppen, é do tipo Cwa, isto é, subtropical úmido, com três meses mais secos (junho, julho e agosto), chuvas de verăo, seca de inverno, temperatura média do mês mais quente superior a $22{ }^{\circ} \mathrm{C}$ e a do mês mais frio inferior a $18{ }^{\circ} \mathrm{C}$. Nesse experimento esperou-se testar o desempenho do tensiômetro de câmara de ar, comparando-a com aquela do tensiômetro convencional, nas condiçōes naturais de clima e solo.

Os tensiômetros foram instalados em uma Terra Roxa Estruturada, em área coberta por seringueira de 8 anos, próximo à estação meteorológica, num total de 90 tensiómetros, dos quais 45 com manómetro de mercúrio e 45 de cámara de ar. A distribuição espacial foi em blocos casualizados, com 30 tensiómetros cada, num total de 3 blocos, distanciados de, aproximadamente, 50 metros entre si. Em cada bloco (Figura 
1), os tensiómetros foram instalados em 3 profundidades (15, 35 e $150 \mathrm{~cm}$ ), com 5 repetiçōes. As repetiçőes distanciavam-se em $1 \mathrm{~m}$ e os pares (mercúrio vs leitura direta) em $0,2 \mathrm{~m}$.

Os tensiômetros foram introduzidos no solo de forma vertical, em escavaçóes feitas com trado de rosca e com piståo, ambos com diâmetro um pouco menor que o diåmetro do tubo de PVC dos tensiómetros. A escavaçăo foi umedecida com água no momento da introdução dos tensiômentros, com o objetivo de facilitar essa introdução. O menor diâmetro da escavação em relação ao diåmetro do tubo dos tensiômetros propiciou um melhor contato da cápsula porosa com o solo, condição exigida para um bom funcionamento do instrumento. $\mathrm{Na}$ superficie do solo, o tubo do tensiómetro foi circundado com borracha, a qual evitou que qualquer fluxo preferencial ocorresse da superficie do solo até a cápsula pela parede externa do tubo.

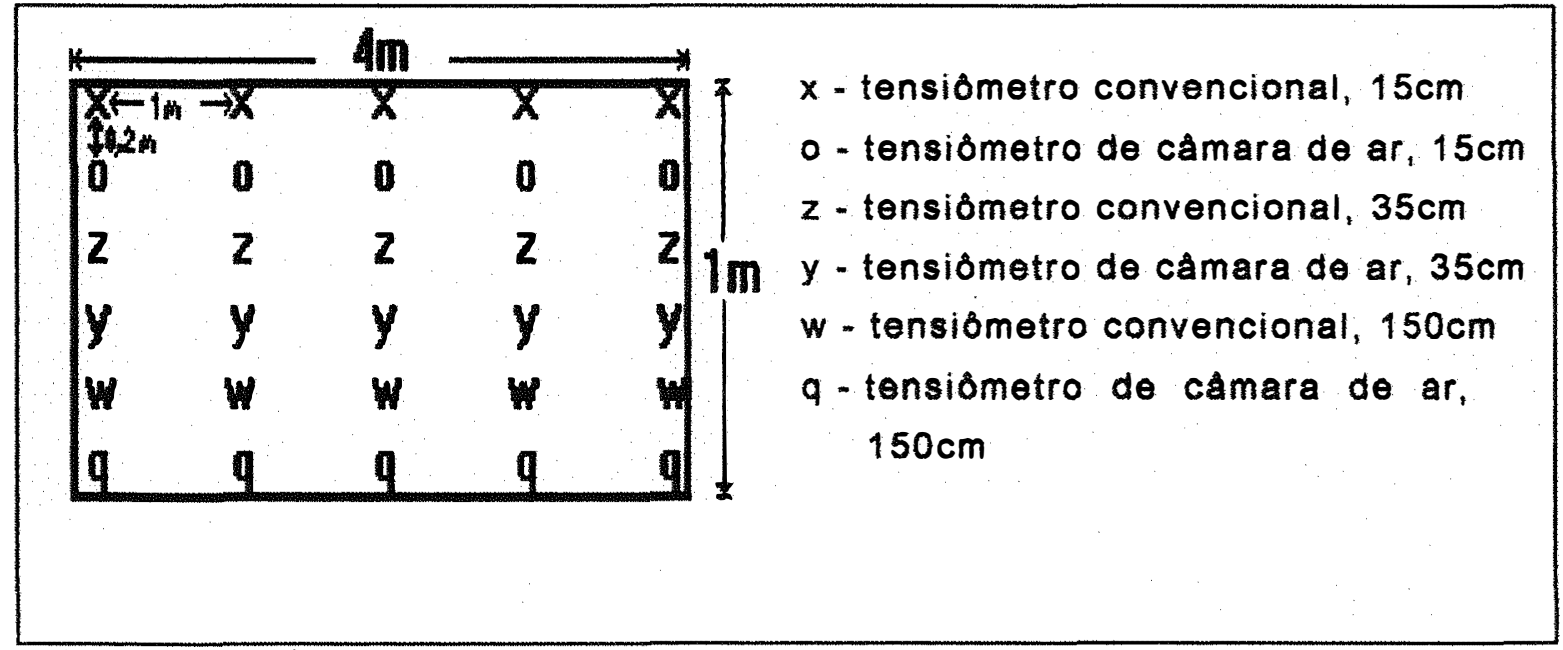

Figura 1 - Croqui de um bloco no experimento de campo

Os tensiômetros tinham tamanhos variados, em funçăo da profundidade de instalaçăo. Os tensiômetros de 



\subsection{Cálculo do potencial da água no solo}

\subsubsection{Tensiómetro com manómetro de mercúrio}

Para esse tipo de tensiômetro (Figura 2) 0 cálculo do potencial mátrico da água no solo foi realizado com o uso da equação seguinte, já consagrada:

$$
\psi_{m}=\left(-12,6 h+h_{c}+z\right) \cdot 0,1
$$

na qual

$$
\begin{aligned}
& \Psi_{m}=\text { potencial mátrico }(\mathrm{kPa}) \\
& \mathrm{h} \text { = Altura de equilibrio da coluna de mercúrio } \\
& \text { (cm) } \\
& h_{c}=\text { altura da superficie do mercúrio no } \\
& \text { reservatório até a superficie do solo }(\mathrm{cm}) \\
& z \text { = profundidade de instalação do tensiómetro } \\
& \text { (cm) } \\
& \text { O fator } 0,1 \text { foi utilizado para transformar os }
\end{aligned}
$$
valores de potencial mátrico de $\mathrm{cm}$ de $\mathrm{H}_{2} \mathrm{O}$ em kPa.

\subsubsection{Tensiômetro de câmara de ar.}

No tensiômetro de leitura direta (figura 3) 0 potencial mátrico da água no solo foi calculado pela utilização da equação desenvolvida por VILLA NOVA et al. (1989), cuja deduçăo pode ser assim demonstrada: 
Um equilibrio de forças dever ser estabelecido entre as pressōes que atuam sobre a cápsula porosa do tensiômetro nos sentidos de dentro para fora e de fora para dentro do tensiômetro.

De fora para dentro atua a pressão atmosférica local. De dentro para fora atuam as pressōes devidas à interação da água com o solo (potencial matrico, $\psi$ m), a pressão hidrostática devida à coluna de água dentro do instrumento (dada pela diferença entre a altura total do instrumento e a altura da câmara no momento da leitura $(H-h c)$ e a pressão do gás na câmara no momento da leitura ( $\left.P^{\prime}\right)$. No equilíbrio tem-se:

$$
P_{\text {atm }}=\psi_{m}+(H-h c)+P^{\prime}
$$

A relação entre $P^{\prime}$ e a pressão inicial, ou seja, do momento do fechamento do tensiómetro é estabelecida pela equação geral dos gases perfeitos:

$$
\begin{aligned}
& P . V / T i=P^{\prime} \cdot V^{\prime} / T f \\
& P^{\prime}=\text { P.V.T.f } / V^{\prime} . T i
\end{aligned}
$$

V e V'são dados, respectivamente, pelo produto das alturas das câmaras inicial e do momento da leitura pela área de secção transversal do tubo. Assim:

$$
P_{\text {atm }}=\psi_{m}+\text { P.h.Tf / hc.Ti }+(H-h c)
$$


A pressão inicial $P$ é igual à pressão atmosférica local, pois ela é a pressão do momento de fechamento do tensiómetro, de tal modo que:

$$
\psi_{m}=P_{\text {atm }}-\left(P_{\text {atm }} \cdot \text { h.Tf } / \text { hc. Ti }\right)+(H-h c)
$$

e

$$
\psi_{m}=\left(-P_{\text {atm }}\left[\left(1-h / h_{c}\right) \cdot(T f / T i)\right]+\left(H-h_{c}\right)\right) \cdot 0,1
$$

onde

$$
\begin{aligned}
\psi_{\mathrm{m}}= & \text { potencial mátrico }(\mathrm{kPa}) \\
\mathrm{p}_{\mathrm{atm}}= & \text { pressão a tmosférica média local }\left(\mathrm{cm} \mathrm{H} \mathrm{H}_{2} \mathrm{O}\right) \\
\mathrm{h}= & \text { Altura da cámara inicial }(\mathrm{cm}) \\
\mathrm{h}_{\mathrm{c}}= & \text { Altura da câmara de equilibrio, por } \\
& \text { ocasião da leitura }(\mathrm{cm})
\end{aligned}
$$

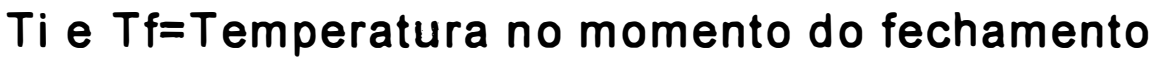
do tensiómetro (condição inicial) e no momento da leitura, respectivamente (K)

$\mathrm{H}=$ Comprimento total do tensiómetro $(\mathrm{cm})$

O fator 0,1 foi utilizado para transformar os valores de potencial mátrico de $\mathrm{cm}$ de $\mathrm{H}_{2} \mathrm{O}$ em $\mathrm{kPa}$. 


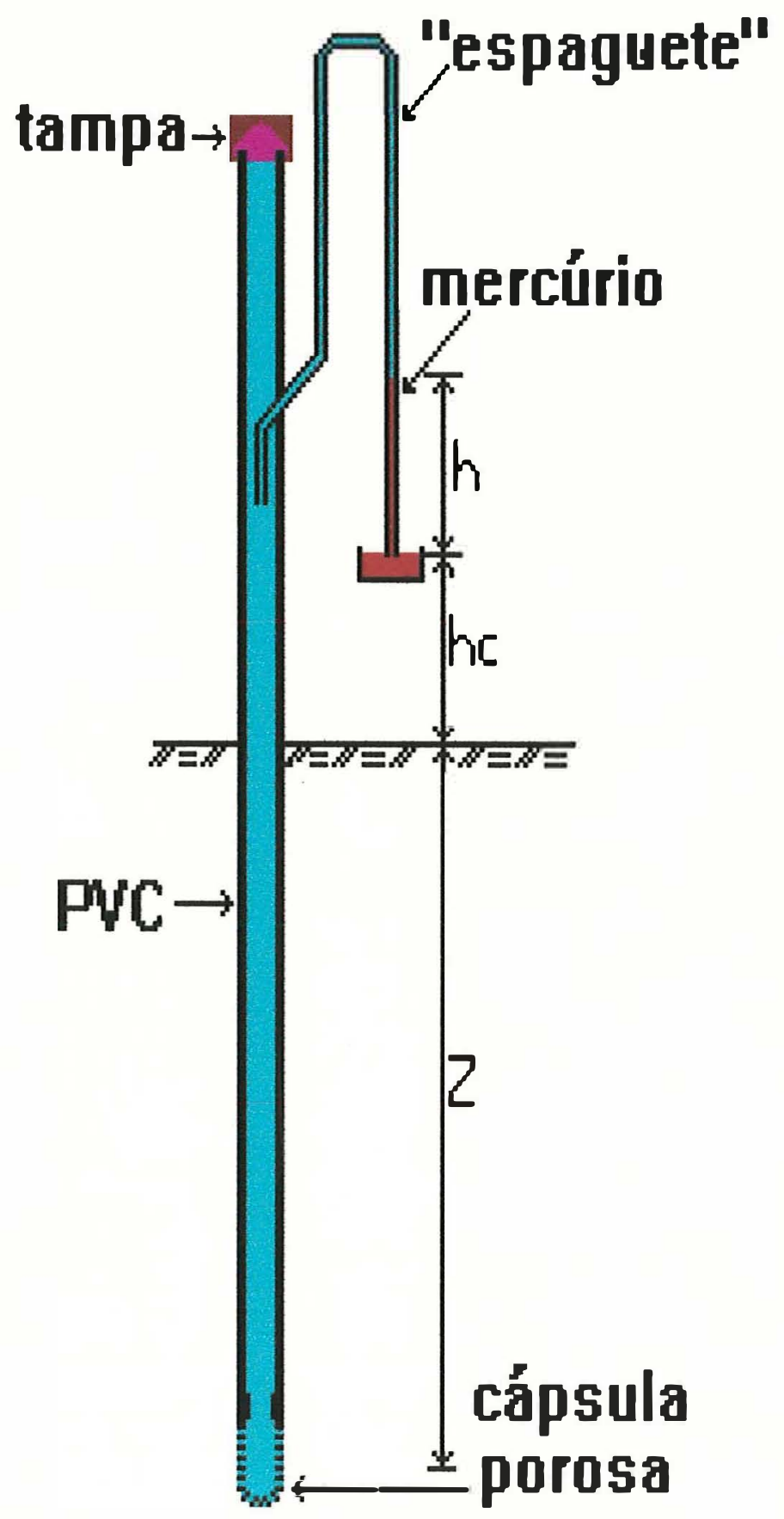

Figura 2 - Modelo esquemático do tensiômetro convencional (manômetro de mercúrio). 


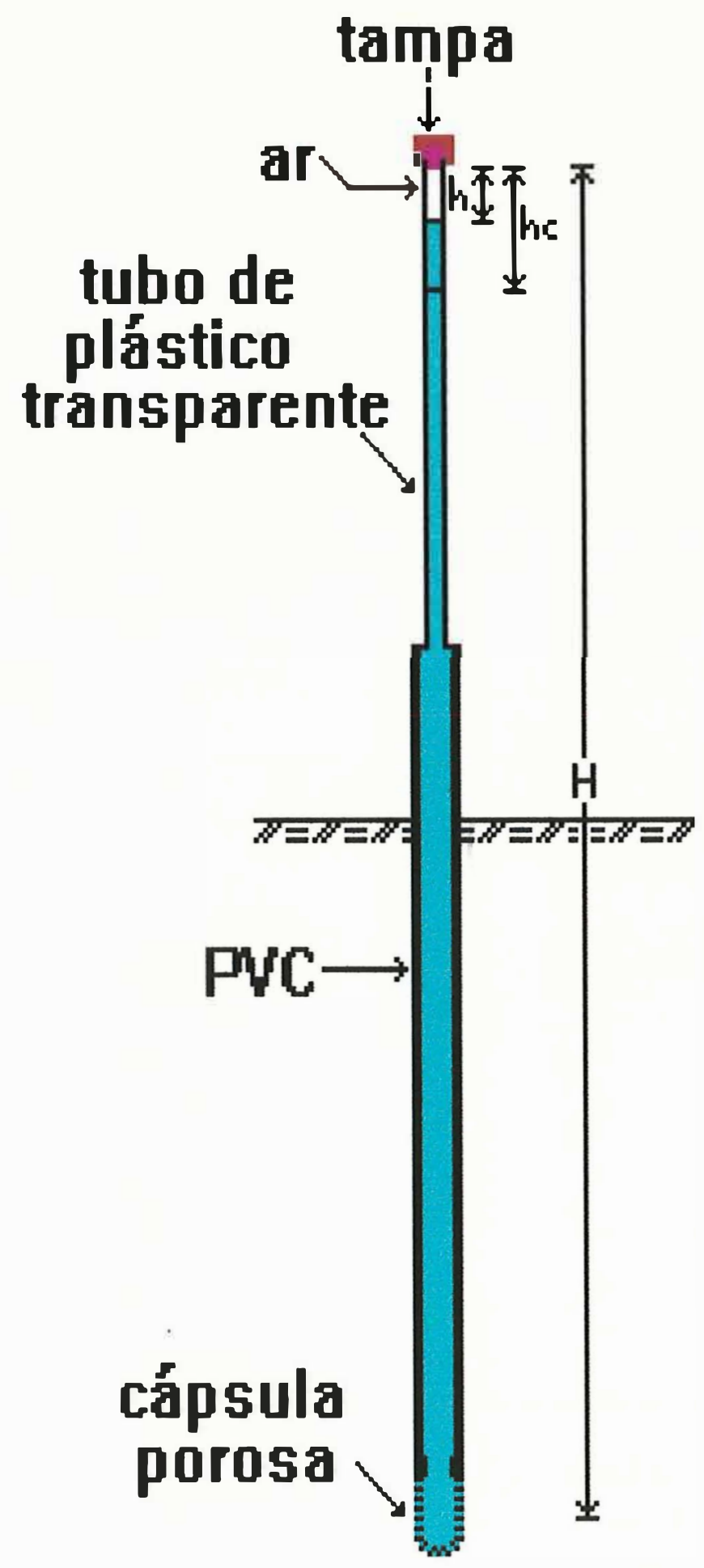

Figura 3 - Modelo esquemático do tensiômetro de câmara de ar 


\section{RESULTADOS E DISCUSSÃO}

\subsection{Experimento de laboratório com tensiómetro de duplo manómetro}

A resposta do tensiômetro de câmara de ar foi observada inicialmente no laboratório, durante 10 dias, com tensiômetro de duplo manómetro. A variaçăo do potencial mátrico com o tempo, durante esse periodo, está apresentada na Tabela 1 e na Figura 4 . Os valores de potencial mátrico positivos na primeira leitura ( 11 de maio, 14 horas) nos dois tipos de tensiómetro săo devidos ao fato de que o equilibrio ainda năo havia sido alcançado, isto é, nem a câmara nem a coluna de mercúrio haviam compensado a coluna de água dentro do tensiómetro, a qual atua exercendo uma pressão sobre a cápsula.

O tempo para que o potencial mátrico no tensiómetro com manómetro de cámara de ar seja correspondente àquele do manómetro de mercúrio foi de aproximadamente duas a três horas, como pode-se perceber dos resultados dos dias 11 e 17 de maio, quando a cápsula do tensiómetro foi reumedecida através de sua introdução em água, tendo o potencial aproximado-se de zero, e novamente exposta às condições ambientais. 
Na Figura 5 é mostrada a correlação entre os potenciais mátricos obtidos pelos dois tipos de manômetro. 0 alto coeficiente de correlação (0.99) denota quão relacionados eles estão. No entanto, para esse caso em que os dois manómetros estão no mesmo tensiômetro, dever-se-ia esperar uma correlaçăo de 1. Contudo, apesar de se assemelharem as respostas dos dois tipos de manómetro, suas naturezas diferentes promovem essas pequenas diferenças, o que é um fato absolutamente aceitável.

Os potenciais obtidos pelo tensiómetro com manômetro de cåmara de ar são, quase que invariavelmente, ligeiramente mais negativos do que os obtidos pelo manômetro de mercúrio. TAMARI et al. (1993) sugerem que a pressão na câmara deve ser corrigida da pressão de saturação de vapor d'água, a qual é da ordem de $2 \mathrm{kPa}$, a $20^{\circ} \mathrm{C}$. Existe um outro aspecto a ser considerado com bastante cuidado. Devido ao diåmetro do tubo transparente, um menisco é formado na interface água/ar dentro do tensiómetro, de modo que a leitura da altura da cåmara deve ser feita com bastante cuidado, devendo-se sempre fazê-la no mesmo ponto em relaçăo ao menisco, visto que, para altos valores de potencial mátrico, um pequeno erro na leitura da altura da cåmara provoca um erro consideravelmente grande no valor do potencial; para baixos valores de potencial mátrico esse problema não é tão crucial, podendo-se considerar como desprezivel o erro provocado no valor de potencial mátrico. Embora TOKUNAGA \& SALVE (1994) tenham apontado como vantagem desse tipo de manómetro a facilidade de leitura, esse é um aspecto que merece atenção 
Tabela 1 - Valores de Potencial mátrico obtidos nos tensiômetros de duplo manômetro (mercúrio e câmara de ar) no experimento de laboratório.

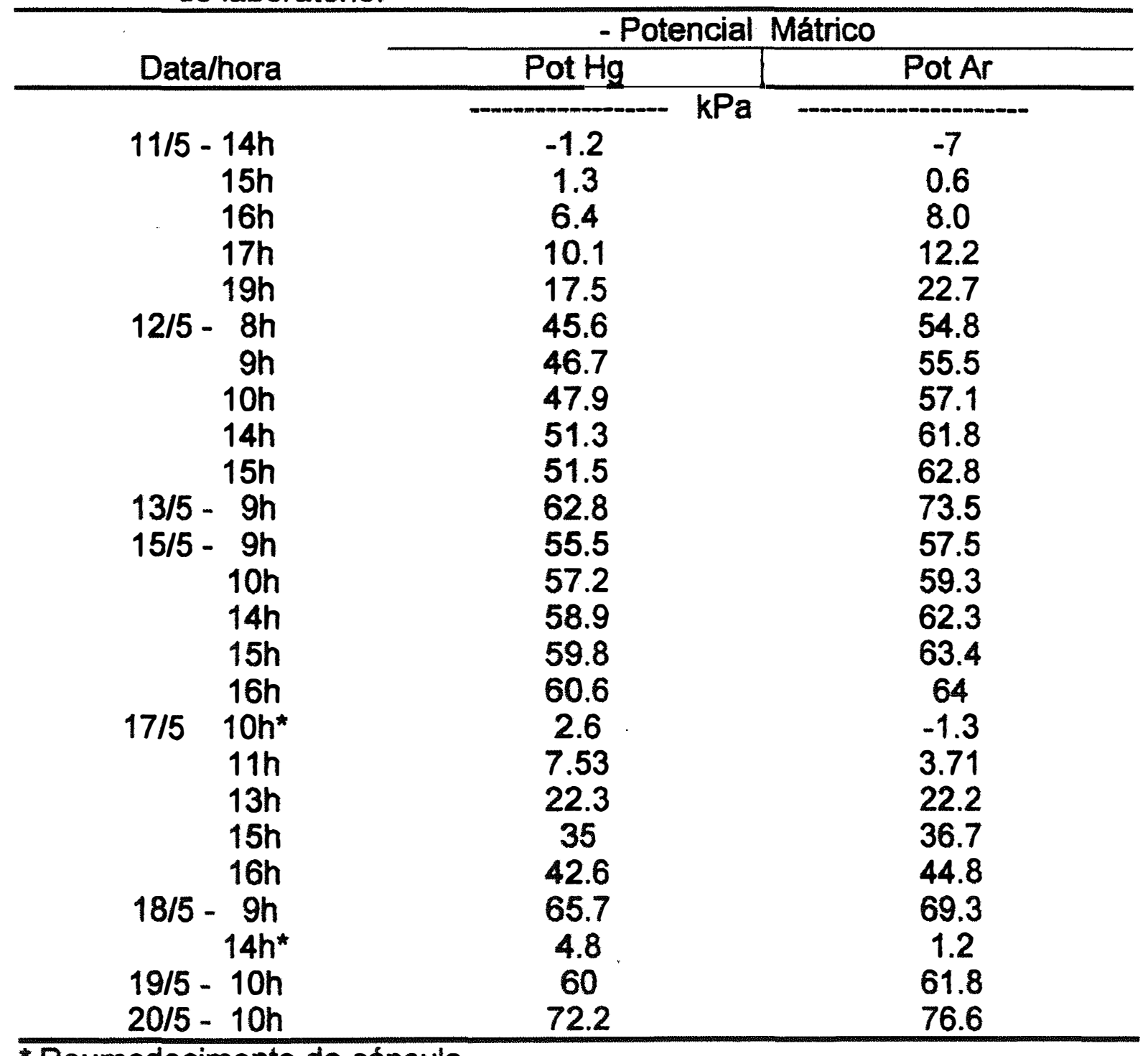

"Reumedecimento da cápsula. 


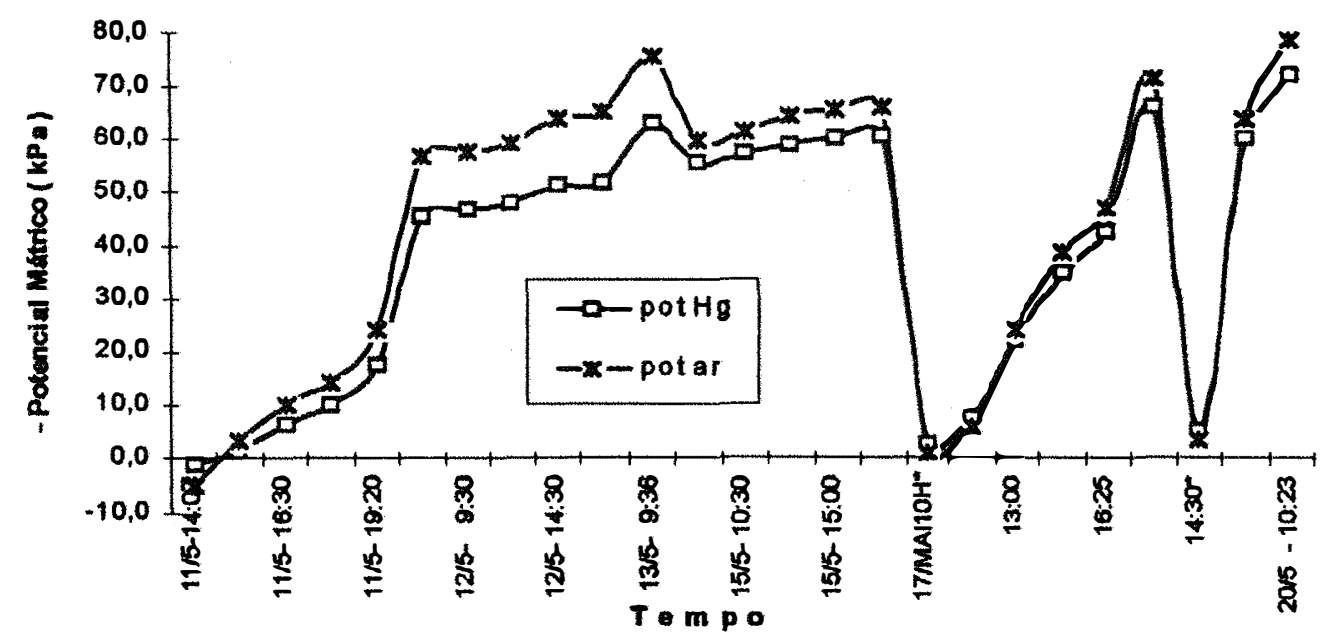

Figura 4. Potencial mátrico versus tempo, tensiômetro de duplo manómetro, experimento de laboratório.

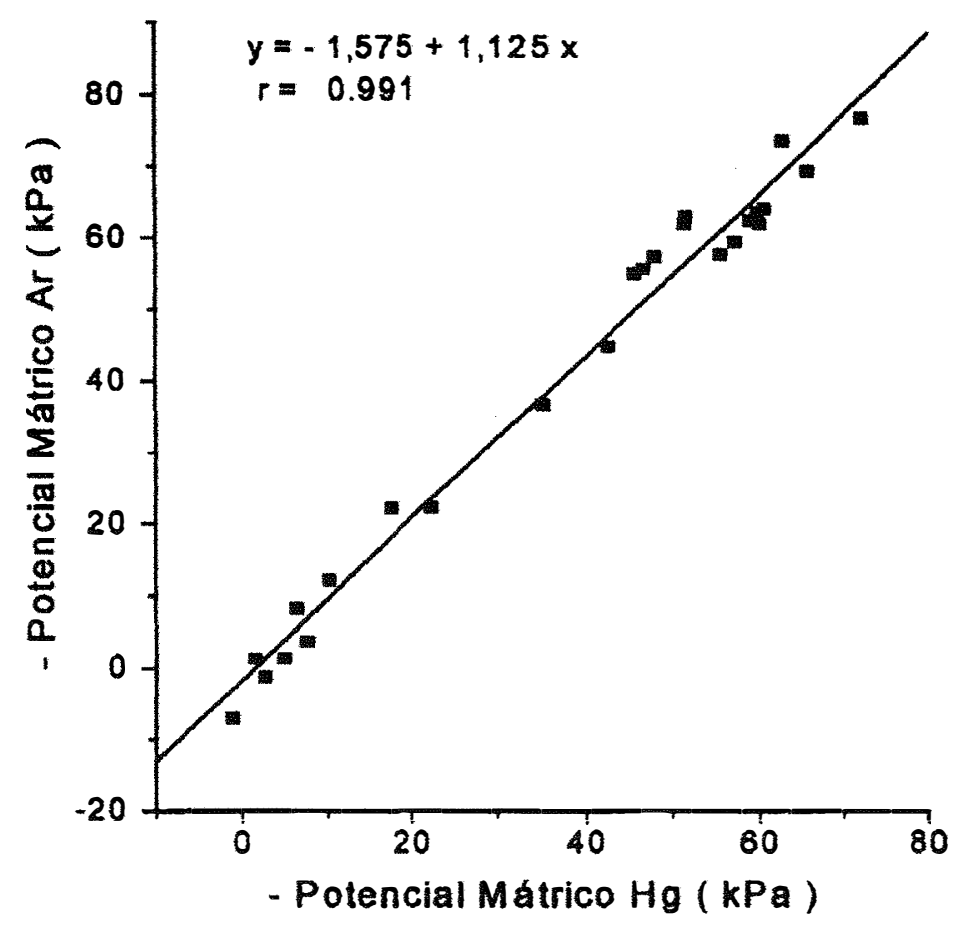

Figura 5. Relação entre potencial mátrico medido por tensiômetro de duplo manómetro (mercúrio e câmara de ar), no laboratório. 
redobrada ao se lidar com esse tipo de manômetro.

Considerando-se que a capacidade de campo corresponde a um potencial mátrico de $-10 \mathrm{kPa}$, o que é razoável dentro da imperfeição na definição do termo, e considerando-se como referência o potencial mátrico medido no manômetro de mercúrio, observa-se, às 17 horas do dia 11 de maio, uma diferença de cerca de $20 \%$ entre os potenciais lidos nos dois manômetros, $-10.1 \mathrm{kPa}$ no tensiômetro de mercúrio e -12.2kPa no de câmara de ar. Essa diferença pode ser causada por um erro de $1 \mathrm{~mm}$ na leitura da câmara, de 36 para $37 \mathrm{~mm}$, o que é plenamente possivel. Para se errar os mesmos $2 \mathrm{kPa}$, nessa faixa de potencial, no tensiômetro de mercúrio, ter-se-ia que errar em aproximadamente $2 \mathrm{~mm}$ na leitura da coluna de mercúrio. Na faixa de potencial mais baixo esse possivel erro na leitura da altura da câmara torna-se menos importante. Por exemplo, no dia 15 de maio, às 16 horas, a diferença entre os potenciais lidos nos dois tipos de manómetro foi de $3,6 \mathrm{kPa}$ (-64kPa no de cámara de ar e $-60.6 \mathrm{kPa}$ no de mercúrio), representando, no entanto, uma diferença de $5 \%$, bem menor do que aquela de $20 \%$ apresentada na faixa de alto potencial mátrico. Além disso, o valor de potencial de $-64 \mathrm{kPa}$ foi obtido a partir de uma câmara de $115 \mathrm{~mm}$ de altura. Para que esse potencial fosse igual ao obtido no manômetro de mercúrio, $-60.6 \mathrm{kPa}$, a altura da câmara deveria ser de $101 \mathrm{~mm}$, isto é, uma diferença de $14 \mathrm{~mm}$, um erro de leitura improvável.

Do ponto de vista prático, para efeito de controle de irrigação, essas pequenas diferenças mostradas pelo manômetro de câmara de ar, em relação ao manômetro de mercúrio, não devem significar a impossibilidade de seu uso 
para tal fim. Em programas de irrigação usando tensiômetros para monitorar a umidade dos solos, vários outros aspectos estão envolvidos no processo, alguns com probabilidade de erros proporcionalmente maiores. Outrossim, na indicação do momento de irrigar, quando o potencial mátrico é baixo, a diferença entre os dois tipos de manômetro, como visto, é pequena, de modo que seu uso é factível.

\subsection{Experimento em laboratório com tensiômetros com manômetros individuais.}

O desempenho do tensiômetro com manómetro de câmara de ar foi observada sob condições de laboratório, em solo homogêneo colocado em vaso, durante 52 dias. Os resultados são mostrados na Tabela 2, e de forma gráfica na Figura 6. Nos dois casos, os valores apresentados de potencial mátrico representa a média das 5 repetições.

A resposta do tensiômetro com manômetro de câmara de ar nessas condições foi semelhante àquela do experimento anterior, ambos em laboratório. De um modo geral, o potencial mátrico medido com tensiômetros com esse tipo de manômetro apresentou valores ligeiramente menores do que os apresentados pelo tensio̊metro com manômetro de mercúrio. Porém, em alguns dias, essa situação se inverteu, mostrando diferenças pontuais de umidade do solo, apesar da homogeneidade que se buscou alcançar. Esses resultados indicam, portanto, uma adequada resposta do tensiômetro com 
manômetro de cåmara de ar às mudanças no conteúdo de água no solo circundante à cápsula.

A correlação entre os valores de potencial mátrico obtidos pelos dois tipos de manômetro foi bastante alta como mostrado na Figura 7 , indicada por um coeficiente de correlação da ordem de 0.98 .

Pela Figura 6 percebe-se que, apesar de pequenas diferenças nos valores absolutos de potencial mátrico entre os dois tipos de manômetro, a semelhança das suas curvas denota uma igualdade de suas respostas, nessas condições em que foram testadas.

O tempo de resposta do tensiómetro de câmara de ar pode ser considerado, nessas condições experimentais, igual àquele com tensiômetro de duplo manômetro, embora as leituras tenham sido diárias - com exceção dos dias 10, 11 e 16 de maio onde foram feitas duas leituras no mesmo dia, e em algumas situações onde a leitura foi feita com até 4 dias de diferença - em contrapartida com as leituras horárias do experimento anterior. Percebe-se, no entanto, que no dia seguinte após o umedecimento do solo, os valores de potencial mátrico dos dois tipos de manómetro já se equivalem. A única exceção ocorreu no período de 14 a 25 de maio, onde a equivalência nos potenciais deu-se num lapso de tempo muito maior que um dia. Diante da regra geral de resposta, porém, não se deve atribuir esse fato a problemas relacionados ao tensiômetro em si, podendo-se, sim, conjecturar que, por algum motivo, as condiçőes de umidade do solo na circunvizinhança das cápsulas possam ter promovido esse comportamento. 
Tabela 2 - Valores médios de Potencial mátrico obtidos nos tensiômetros de manômetro de mercúrio e de câmara de ar, no experimento de laboratório (média de 5 repetições).

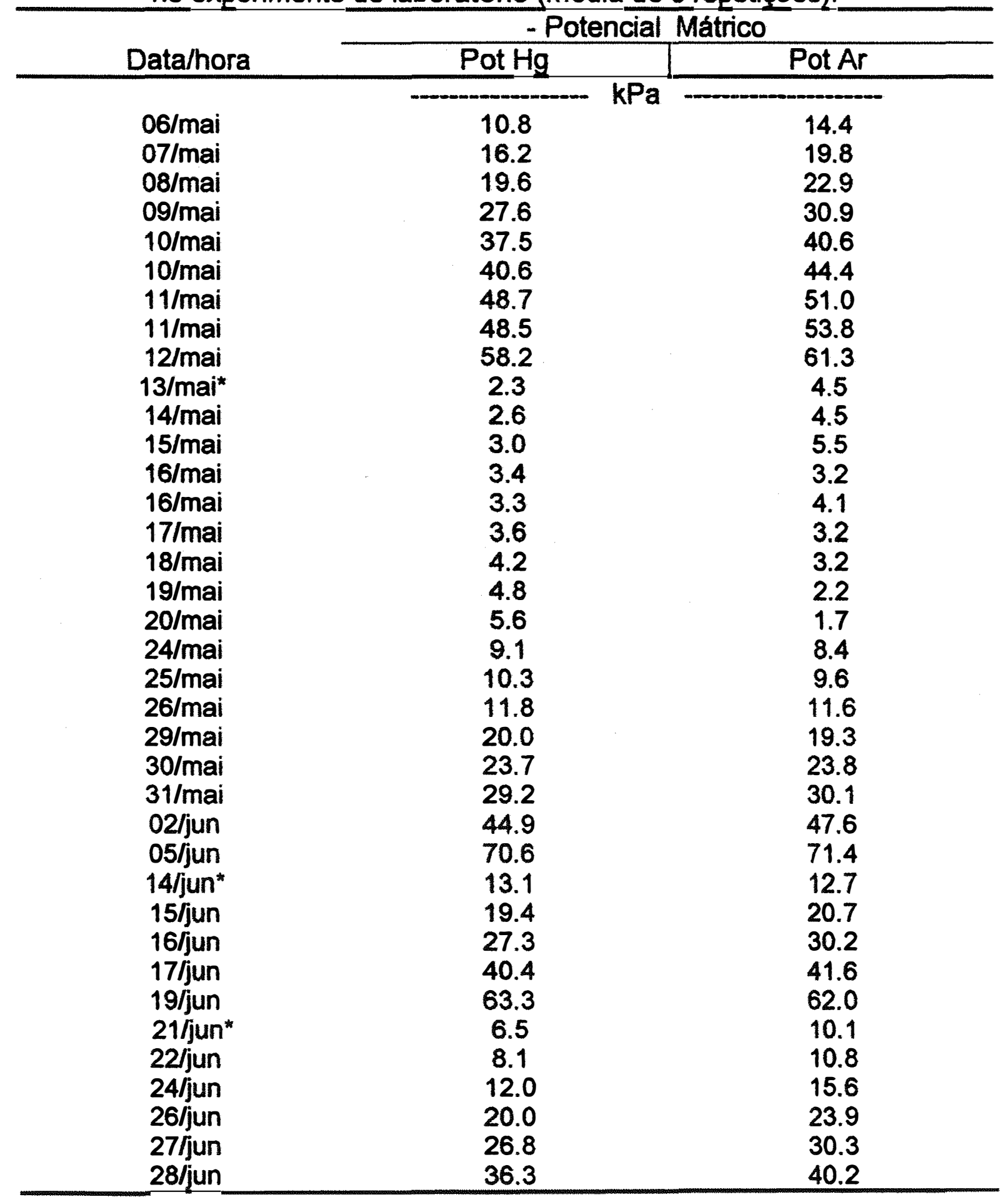

"Reumedecimento do solo 


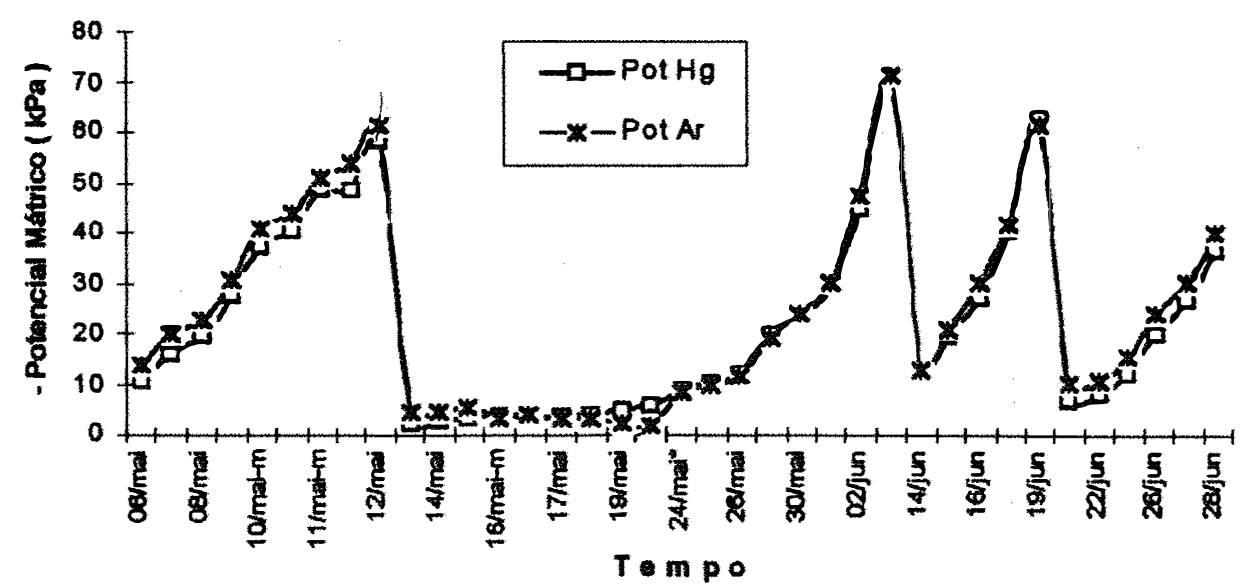

Figura 6. Potencial mátrico versus tempo no expeimento realizado no laboratório com tensiômetros com manômetros individuais (média de 5 repetições)

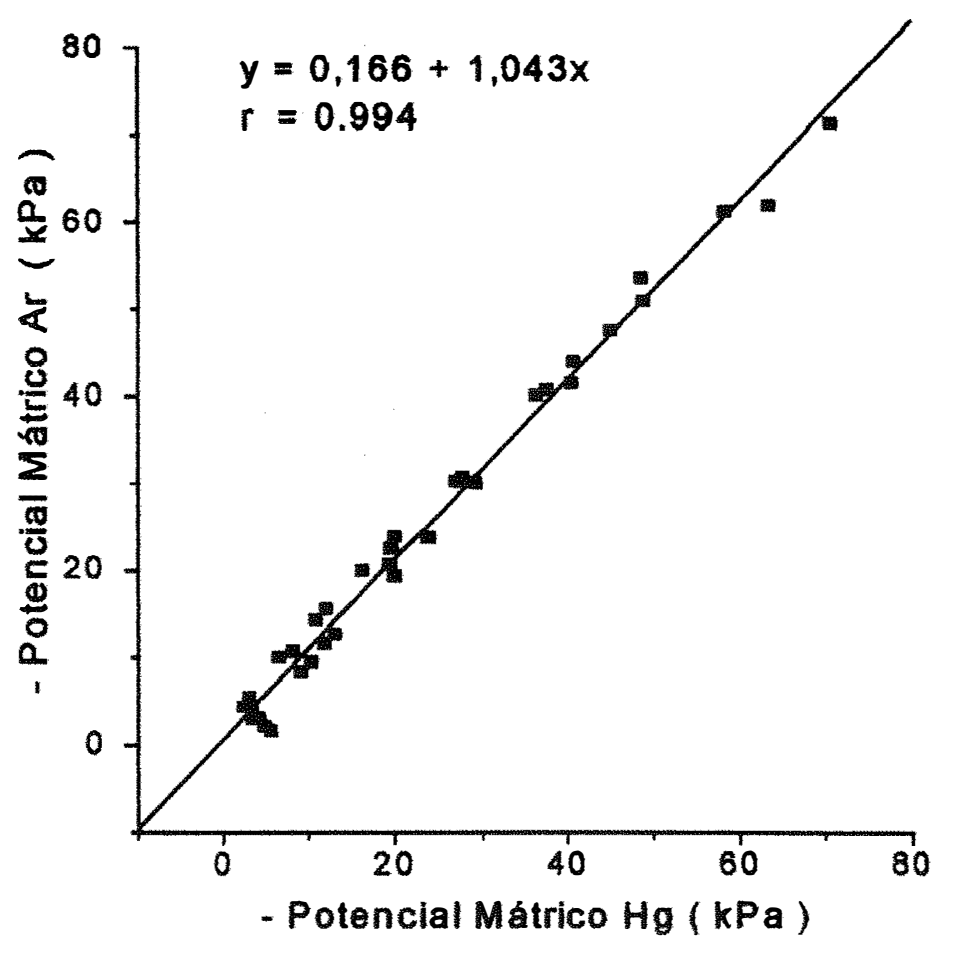

Figura 7. Relaçăo entre potencial mátrico obtido por tensiômetros com manómetros de mercúrio e de câmara de ar, experimento de laboratório (média de 5 repetiçőes). 
A temperatura ambiente no laboratório permaneceu em torno de $24.5{ }^{\circ} \mathrm{C}$ durante o periodo de condução do experimento, de tal modo que essa componente não foi considerada na equação 3.3 para o cálculo do potencial mátrico nos tensiômetros com manómetros de câmara de ar. Assim, a equação 3.3 foi reduzida a:

$$
\psi_{m}=(-p(1-h / h c)+(H-h c)) \cdot 0,1
$$

\subsection{Experimentos sob condições de campo}

O experimento no campo foi instalado e conduzido de acordo com as condições referidas no capitulo material e métodos. Para fins de cálculos e acompanhamento do potencial mátrico, no entanto, nem sempre foi possivel a coleta de dados de todos os tensiómetros instalados, pois, em alguns momentos de leitura, um ou outro tensiómetro apresentava algum tipo de problema, tais como entrada de ar no sistema ou até mesmo a coluna de mercúrio se rompia e o tensiômetro deixava de funcionar. $\mathrm{Na}$ avaliação feita neste capítulo, utilizaremos-nos de alguns dados que julgamos mais consistentes, em função da menor variabilidade das repetiçőes, e suficientes para explicar os resultados. O número de tensiómetros em funcionamento no momento da leitura é anotado. Os demais valores de potencial mátrico serão colocados em forma de apêndices, apenas para efeito de exposição do que foi observado ou para possivel consulta que o leitor possa julgar necessária. 


\subsubsection{Periodo seco}

Na primeira fase do experimento de campo, realizada no mês de setembro, um período de estiagem, o solo encontrava-se bastante seco. Por esse motivo, a coleta de dados tensiométricos nas profundidades de 15 e $35 \mathrm{~cm}$ foi tomado apenas em um único dia ( 2 de setembro), pois os baixos teores de água no solo correspondiam a um potencial mátrico muito baixo, indo além da faixa de funcionamento do tensiômetro com manômetro de mercúrio. Seria possível continuar fazendo as medidas do potencial mátrico através do tensiômetro com manômetro de cåmara de ar; isso, porém, não foi feito por causa da ausência dos dados comparativos de referência dos tensiômetros de mercúrio. A $150 \mathrm{~cm}$ de profundidade, onde o solo permanecia úmido, o monitoramento do potencial foi feito durante 12 dias.

Na Figura 8.a observa-se o comportamento dos dois tipos de manômetros na medida do potencial mátrico da água (valores médios) no solo para o bloco $1,15 \mathrm{~cm}$ de profundidade. Houve uma diminuição constante nos valores de potencial, igualmente medida pelos dois manômetros. O tensiômetro com manômetro de câmara de ar respondeu com rapidez equivalente ao de manômetro de mercúrio, pois na primeira leitura, uma hora após a fluxagem, eles apresentaram aproximadamente o mesmo potencial. Na leitura seguinte, duas horas após a fluxagem, o tensiômetro com manômetro de câmara de ar acusava um potencial ligeiramente mais negativo que o de manômetro de mercúrio, situação que permaneceu até o final 
do dia, quando as leituras foram interropidas devido aos baixos valores de potencial. Essa resposta é semelhante àquela encontrada sob condições de laboratório. Porém, em condições de campo, fatores ligados às propriedades hidricas do solo podem fazer com que a resposta mude pontualmente devido a variabilidade espacial do solo (VILLAGRA et al., 1988; THOMAS $\varepsilon$ PHILLIPS, 1991; HENDRICKX et al., 1994). A verdade desta afirmativa é confirmad́a pelos resultados observados no mesmo bloco I, à profundidade de $150 \mathrm{~cm}$, onde se deu o inverso, ou seja, o potencial lido com manómetro de mercúrio foi sempre menor que aquele lido com tensiómetros com manómetros de câmara de ar (Figura 8.b). Igual comportamento pode-se observar para a profundidade de $35 \mathrm{~cm}$ no bloco II (Figura 8.c). Os coeficientes de correlaçăo de 0.99 e 0.91 no bloco 1 , profundidades de 15 e $150 \mathrm{~cm}$, respectivamente, e de 0.99 , a $35 \mathrm{~cm}$ de profundidade no bloco II, mostrados na figura 9, revelam semelhanças entre os valores de potencial mátrico estimados pelos dois tipos de manômetros, podendo-se considerar que as pequenas diferenças verificadas entre eles săo decorrentes muito mais das diferenças nas condiçőes hidricas do solo do que de problemas inerentes aos instrumentos, não podendo, por isso, serem consideradas dentro de um nivel de importáncia que invalidem o uso do tensiômetro com manômetro de câmara de ar no monitoramento do potencial mátrico da água no solo em situações nas quais um exagerado rigor de exatidão dessas medidas năo seja necessário.

Como verifica-se na Figura 8.a e 8.c, o 

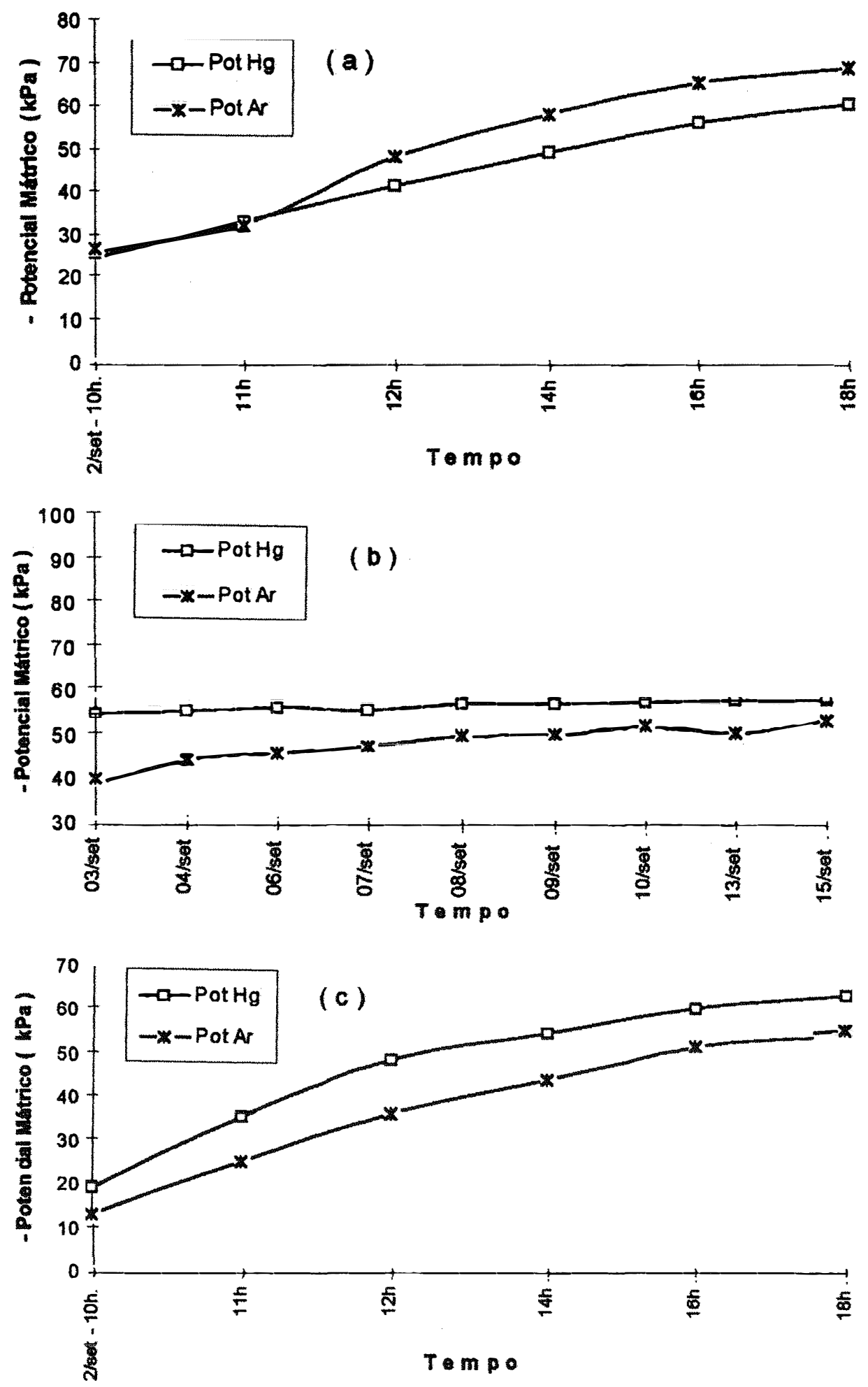

Figura 8. Evoluçăo do potencial mátrico no tempo. $8 \mathrm{a}$ e $8 \mathrm{~b}$ correspondem às profundidades de 15 e $150 \mathrm{~cm}$, respectivamente, no bloco $\mathrm{I} .8 \mathrm{c}$ corresponde à profundidade de $35 \mathrm{~cm}$, bloco 11 . 

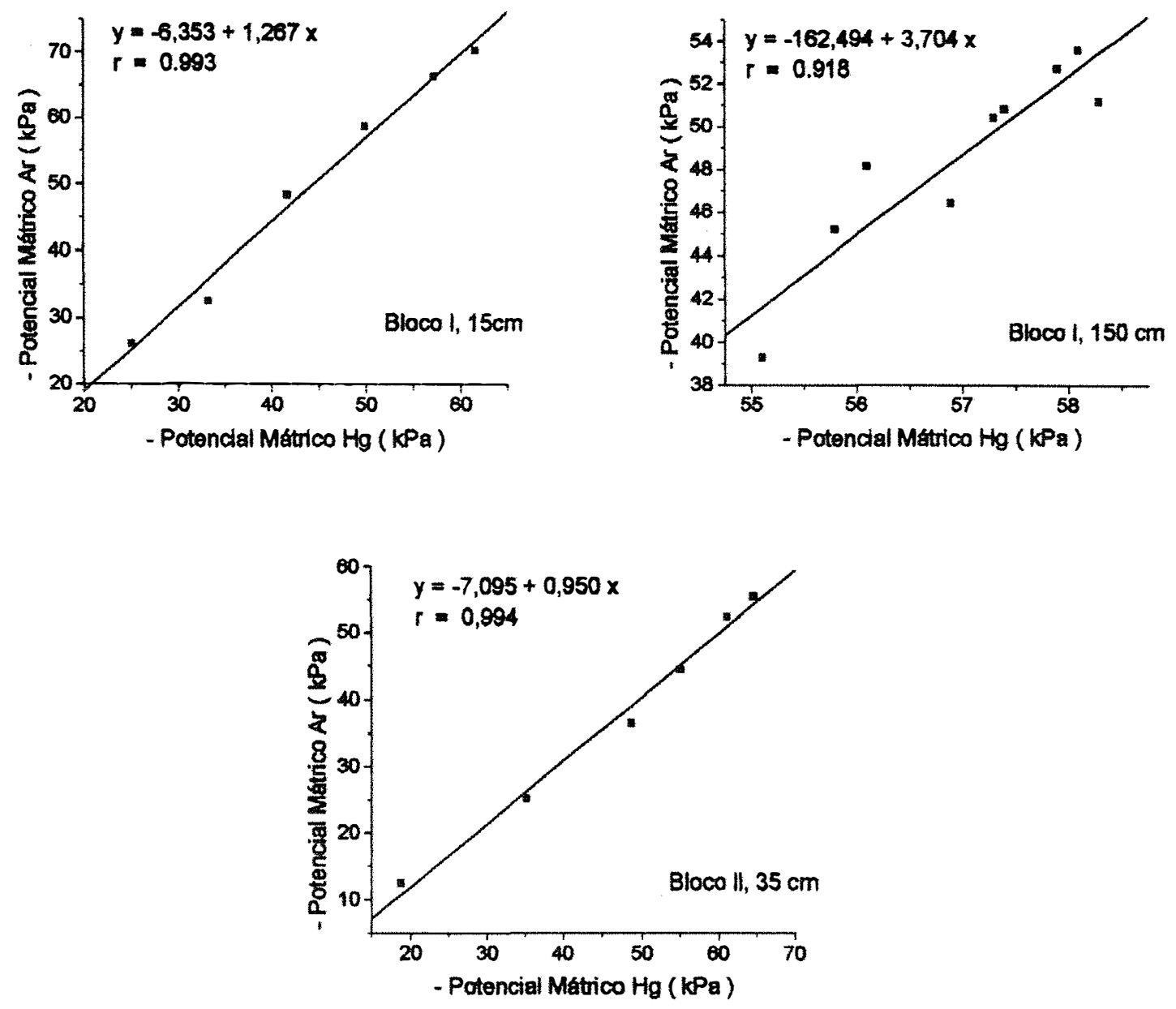

Figura 9. Relação entre potencial mátrico obtido por tensiômetro convencional e de câmara de ar. Experimento de campo, período seco.

potencial mátrico diminuiu ao longo do tempo até valores próximos a -70Kpa, sendo essas mudanças detectadas por ambos os manômetros. A $150 \mathrm{~cm}$ de profundidade (figura $8 \mathrm{~b}$ ), 0 potencial mátrico praticamente não variou ao longo dos 12 dias em que o monitoramento foi realizado. Também nesse caso o tensiômetro com manômetro de câmara de ar mostrou-se hábil 
em responder a essa situação de umidade praticamente constante ao longo do tempo, de modo semelhante ao tensiómetro com manómetro de mercúrio.

\subsubsection{Período úmido}

A condução do experimento em condições de solo úmido foi feita em duas etapas distintas. A primeira se deu no periodo de 22 a 28 de novembro, logo após a ocorréncia de uma chuva. A segunda foi realizada em janeiro, quando as precipitaçőes pluviométricas foram mais frequentes.

Da primeira fase vale ressaltar os resultados observados no bloco I, apresentados na Figura 10. A resposta dos dois tensiômetros (convencional e com manômetro de câmara de ar) foi praticamente a mesma para o periodo observado, nas três profundidades consideradas. Como não houve chuva durante o periodo de observaçăo, o potencial mátrico diminuiu com o tempo nas profundidades de 15 e $35 \mathrm{~cm}$ e os dois tipos de tensiômetros responderam de modo absolutamente equivalente.

Parte da água que deixava o solo nas profundidades de 15 e $35 \mathrm{~cm}$ estava evapotranspirando e parte infiltrando para profundidades maiores do solo. Esse fato foi comprovado pelos tensiômetros instalados a $150 \mathrm{~cm}$ de profundidade, nos quais 0 potencial mátrico foi aumentando nesse periodo, como pode ser verificado na Figura 10c, apontado pelas curvas referentes aos dois tipos de manômetro. Isto significa que o tensiômetro com manómetro de câmara de ar pode ser utilizado, assim como sugerido para o tensiômetro com manómetro de mercúrio, para 

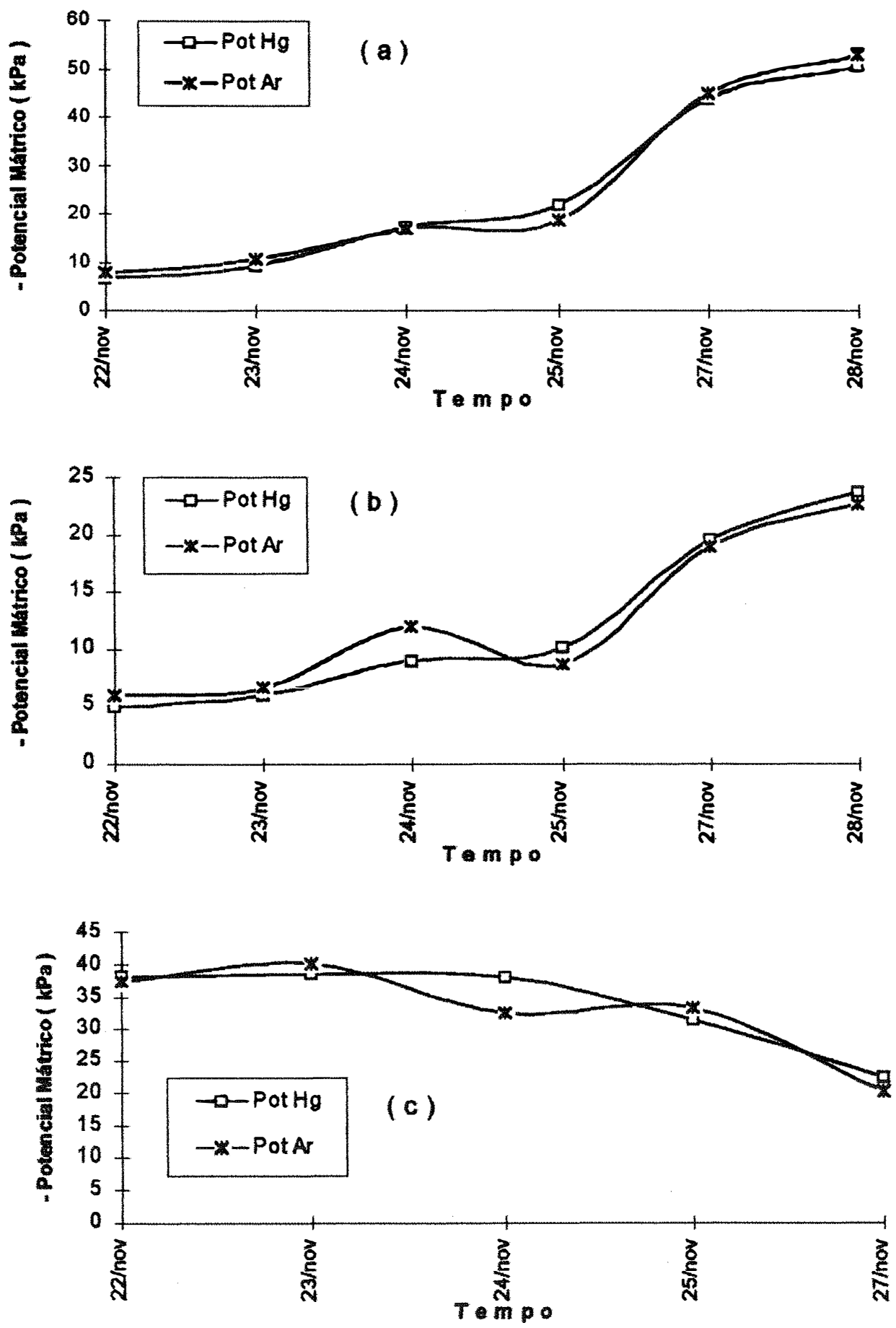

Figura 10. Evoluçăo do potencial mátrico no tempo para o experimento de campo, primeiro periodo úmido. Bloco I (a) $15 \mathrm{~cm}$; (b) $35 \mathrm{~cm}$ e (c) $150 \mathrm{~cm}$. 

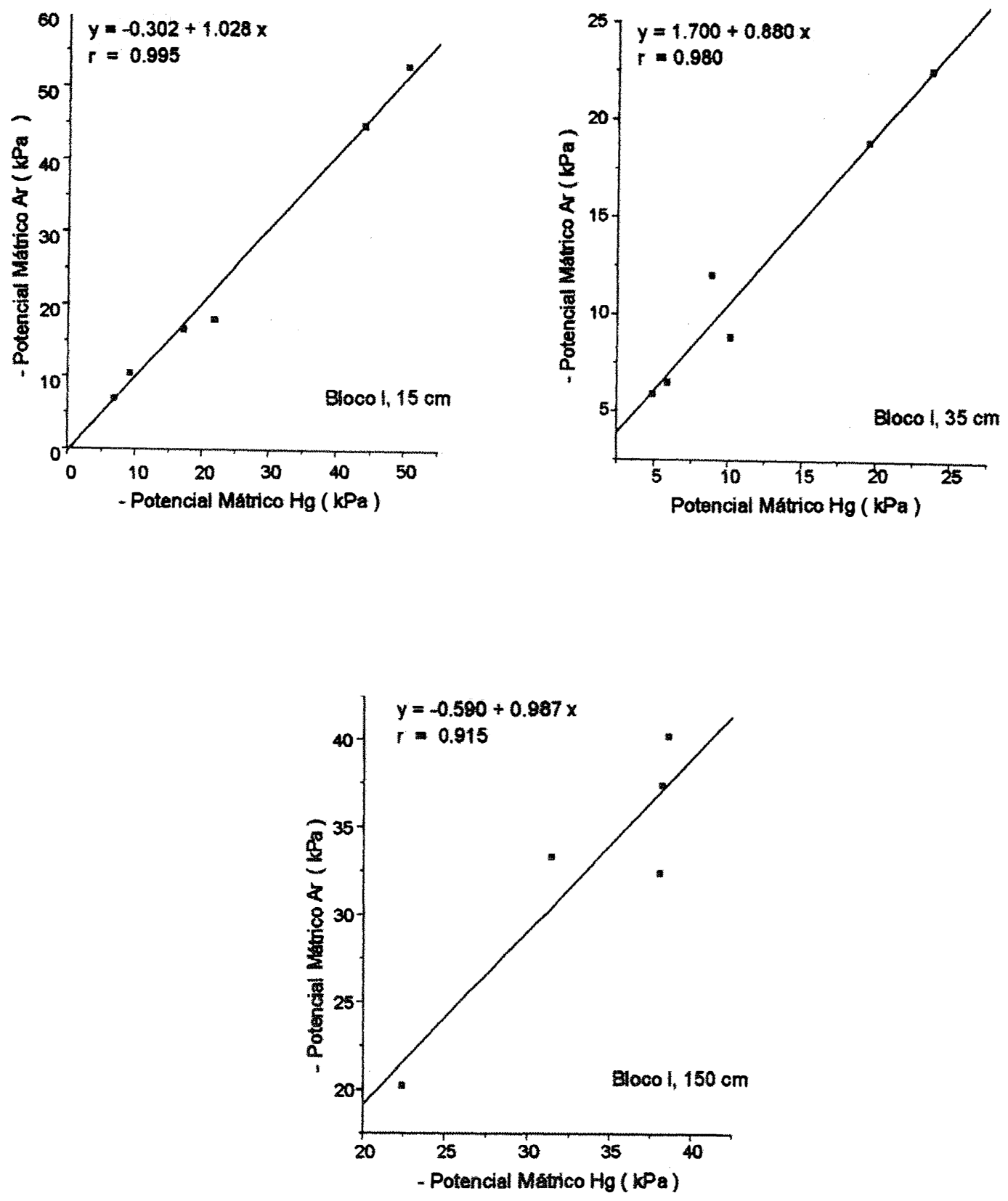

Figura 11. Relação entre potencial mátrico obtido por tensiómetro convencional e de câmara de ar. Experimento de campo, primeiro período úmido 
estudos de fluxo de água em condições de solo não saturado (SINGH et al., 1988; BOOLTINK \& BOUMA, 1991), também para armazenamento da água no solo e sua disponibilidade para as plantas (WERKHOVEN, 1992), para estudos de déficit hídrico (BEZERRA, 1995), entre outras aplicações. As equações de regressão e os coeficientes de correlaçăo para esse período são mostrados na Figura 11.

Outra série de leituras foi feita durante o mês de janeiro quando, devido a pequenas e freqüentes chuvas, o solo permaneceu com elevado conteúdo de água. Dessa forma, pequenas variações no conteúdo de água e, conseqüentemente, nos valores de potencial mátrico, deveriam ser acusados pelos tensiômetros. Com esse objetivo foram feitas leituras horárias durante os dois primeiros dias do periodo.

Para esse período foram feitos os cálculos do desvio padrăo e coeficiente de variaçăo dos valores de potencial mátrico, a partir das repetições, para os três blocos e nas três profundidades. Algumas dessas situações serão aqui comentadas, outras serăo colocadas na forma de apêndices.

$\mathrm{Na}$ Tabela 3 e Figura 12 a săo apresentados os resultados observados nos dois tipos de tensiómetros para o bloco $1,15 \mathrm{~cm}$ de profundidade. Observa-se que, durante os dias 12 e 13 de janeiro, a umidade do solo decresceu lentamente, promovendo uma lenta diminuiçăo do potencial mátrico; a partir do dia 16 o potencial decresceu de forma mais acentuada. Pela Figura 12a percebe-se que o comportamento dos dois tipos de tensiômetros foi semelhante e isto indica que, nesse caso, ambos foram adequados no monitoramento do potencial. 
Tabela 3 - Média, desvio padrăo e coeficiente de variação dos valores de potencial mátrico obtidos por tensiômetro de mercúrio e de câmara de ar, bloco $1-15 \mathrm{~cm}$ de profundidade.

\begin{tabular}{|c|c|c|c|c|c|c|c|c|}
\hline \multirow[t]{2}{*}{ Data } & \multicolumn{4}{|c|}{ Tensiômetro de Mercúrio } & \multicolumn{4}{|c|}{ Tensiômetro de Câmara de Ar } \\
\hline & $\mathbf{N}$ & Média & DesPad & CV & $\mathbf{N}$ & Média & DesPad & CV \\
\hline & & $-\ldots+1$ & $\mathrm{~Pa} \cdots$ & $\%$ & & $-\infty$ & $\mathrm{Pa} \ldots$ & $\%$ \\
\hline 12/jan & 5 & 1.5 & 0.13 & 8.8 & 5 & 1.1 & 0.15 & 13.0 \\
\hline 12/jan & 5 & 1.6 & 0.19 & 11.9 & 4 & 2.2 & 0.18 & 8.5 \\
\hline $12 / j$ & 5 & 1.9 & 0.23 & 11.9 & 4 & 3.1 & 1.31 & 41.9 \\
\hline $12 / \mathrm{j}$ & 5 & 2.1 & 0.20 & 9.67 & 4 & 3.1 & 1.52 & 51.3 \\
\hline 12/jan & 5 & 2.3 & 0.23 & 10.0 & 4 & 3.9 & 0.96 & 24.5 \\
\hline 12/jan & 5 & 2.4 & 0.29 & 12.1 & 4 & 4.2 & 1.01 & 24.0 \\
\hline $12 / j$ & 5 & 2.5 & 0.27 & 11.0 & 4 & 3.3 & 1.08 & 32.7 \\
\hline $13 / j$ & 5 & 2.9 & 0.33 & 11.5 & 4 & 3.9 & 1.08 & 27.6 \\
\hline 13/jan & 5 & 2.9 & 0.32 & 11.2 & 4 & 3.6 & 0.14 & 3.9 \\
\hline 13/jan & 5 & 2.9 & 0.32 & 11.1 & 4 & 3.6 & 1.31 & 36.1 \\
\hline 13/jan & 5 & 3.0 & 0.37 & 12.3 & 4 & 3.9 & 1.24 & 31.5 \\
\hline 13/jan & 5 & 3.4 & 0.39 & 11.5 & 4 & 5.9 & 0.18 & 3.1 \\
\hline 13/jan & 5 & 3.5 & 0.42 & 12.0 & 4 & 5.7 & 1.81 & 31.9 \\
\hline 13/jan & 5 & 3.9 & 0.44 & 11.3 & 4 & 6.5 & 0.98 & 14.9 \\
\hline 13/jan & 5 & 4.3 & 0.73 & 16.8 & 4 & 7.5 & 1.13 & 15.0 \\
\hline 13/jan & 5 & 4.4 & 0.81 & 18.4 & 4 & 9.6 & 1.18 & 12.1 \\
\hline 16/jan & 5 & 18.3 & 9.27 & 49.1 & 4 & 16.8 & 3.47 & 16.5 \\
\hline 17/jan & 5 & 31.5 & 14.40 & 45.6 & 4 & 30.7 & 5.97 & 15.5 \\
\hline & 5 & 41.9 & 16.10 & 38.3 & 4 & 42.4 & 7.82 & 14.7 \\
\hline 20/jan & 5 & 59.6 & 12.30 & 20.7 & 4 & 63.3 & 7.16 & 9.0 \\
\hline
\end{tabular}

$\mathrm{N}$ - Número de tensiômetros em funcionamento no momento da leitura. DesPad - Desvio Padrão

CV - Coeficiente de Variação 

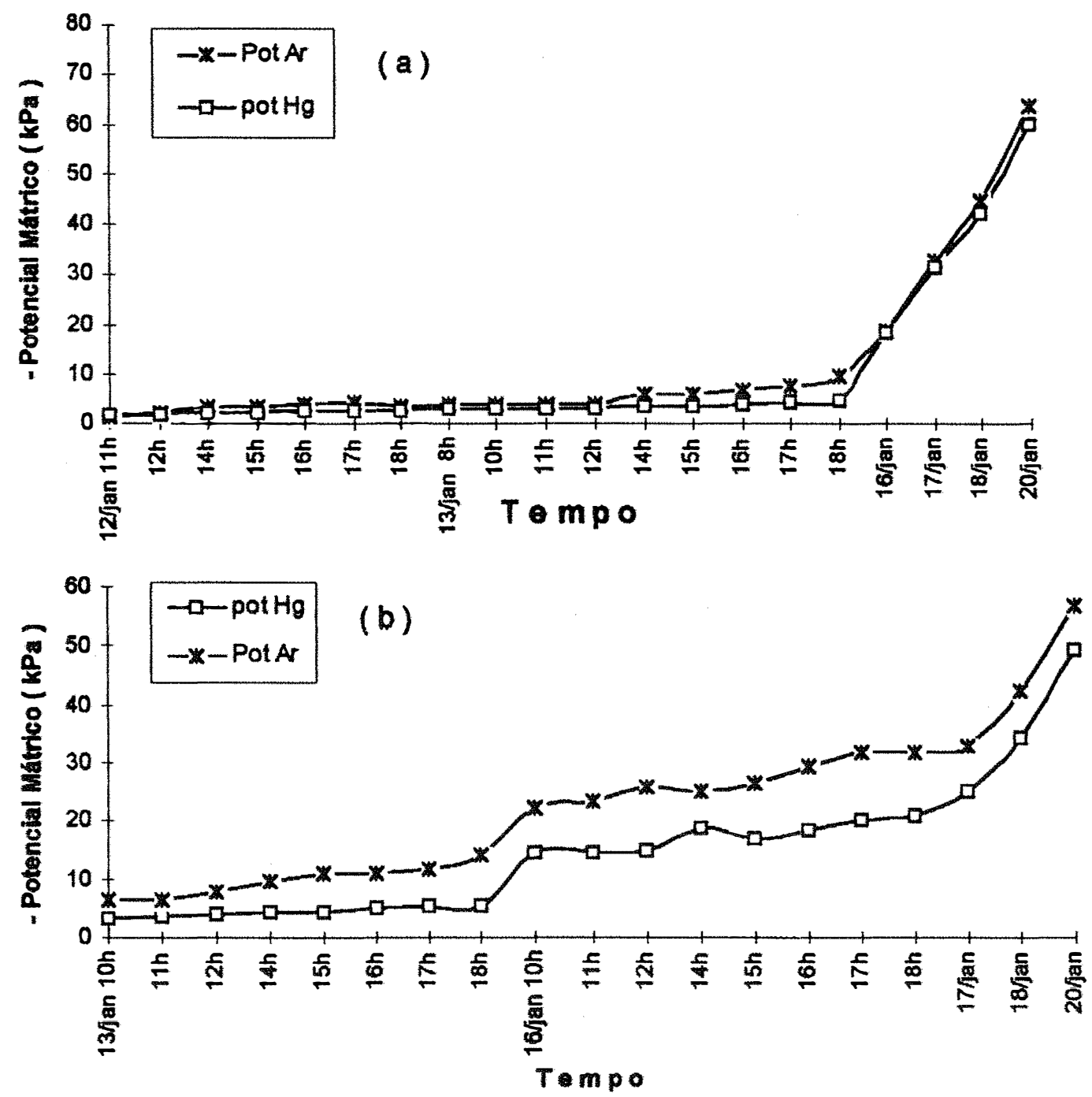

Figura 12. Evolução do potencial mátrico no tempo no experimento de campo, segundo período úmido. (a) bloco $1,15 \mathrm{~cm}$ e (b) bloco $11,15 \mathrm{~cm}$. 
Os coeficientes de variação apresentados na Tabela 3 estão, na sua grande maioria, dentro de uma faixa aceitável. Em alguns casos, porém, ocorreu uma variação bastante alta entre as repetições, nos dois tipos de tensiômetros. Não causam surpresa, no entanto, quando se trata da medida do potencial mátrico da água no solo, cuja variabilidade espacial é sabidamente muito alta. HENDRICKX $\varepsilon$ WIERENGA (1990) encontraram valores da ordem de $121.4 \%$ em uma área bem pequena.

Os valores de potencial mátrico obtidos a partir dos dois tipos de tensiômetros foram, algumas vezes, um tanto diferentes em termos absolutos, como é o caso verificado no bloco II, $15 \mathrm{~cm}$ de profundidade, visto na Figura 12b. A propensão geral das curvas, como pode-se notar pela figura, é a mesma; no entanto, os valores de potencial mátrico calculados a partir do tensiômetro de câmara de ar são consideravelmente mais negativos. É possivel que apenas a variabilidade espacial não explique totalmente esse comportamento, entretanto, sua contribuição certamente existe. O tensiômetro com manómetro de câmara de ar apresentou uniformidade entre as suas repetições, vistos seus baixos desvios padrão e coeficientes de variação (Tabela 4), indicando que eles estavam funcionando bem, do que se pode deduzir que seus resultados são corretos, apesar da diferença com relação ao tensiômetro convencional, com manômetro de mercúrio, que, nesse caso, apresentou coeficientes de variação bem mais altos. 
Tabela 4 - Média, desvio padrão e coeficiente de variação dos valores de potencial mátrico obtidos por tensiômetro de mercúrio de câmara de ar, bloco $11-15 \mathrm{~cm}$ de profundidade.

\begin{tabular}{|c|c|c|c|c|c|c|c|c|}
\hline \multirow[b]{2}{*}{ Data } & \multicolumn{3}{|c|}{ Tensiómetro de Mercúrio } & \multirow{3}{*}{$\frac{\text { CV }}{\%}$} & \multicolumn{4}{|c|}{ Tensiómetro de Cámara de Ar } \\
\hline & $\mathrm{N}$ & Média & DesPad & & $\mathbf{N}$ & Média & DesPad & CV \\
\hline & & 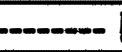 & a --.--- & & & $-\ldots k$ & a ----- & $\%$ \\
\hline 13/jan & 4 & 3.2 & 0.4 & 15.1 & 4 & 6.3 & 1.1 & 17.8 \\
\hline 13/jan & 4 & 3.5 & 0.5 & 14.1 & 4 & 6.3 & 2.1 & 33.6 \\
\hline 13/jan & 4 & 3.8 & 0.5 & 15.5 & 4 & 7.7 & 1.2 & 16.5 \\
\hline 13/jan & 4 & 4.2 & 0.6 & 14.9 & 4 & 9.5 & 1.9 & 20.5 \\
\hline 13/jan & 4 & 4.4 & 0.6 & 14.4 & 4 & 10.8 & 1.1 & 10.9 \\
\hline 13/jan & 4 & 4.8 & 0.9 & 19.6 & 4 & 11.0 & 1.1 & 10.6 \\
\hline 13/jan & 4 & 5.2 & 1.1 & 21.6 & 4 & 11.5 & 1.1 & 10.1 \\
\hline 13/jan & 4 & 5.4 & 1.3 & 24.9 & 4 & 14.0 & 1.1 & 8.0 \\
\hline 16/jan & 5 & 14.3 & 6.0 & 42.1 & 4 & 22.3 & 1.8 & 8.2 \\
\hline 16/jan & 5 & 14.4 & 5.8 & 40.4 & 4 & 23.4 & 1.6 & 6.9 \\
\hline 16/jan & 5 & 14.6 & 5.6 & 38.2 & 4 & 25.2 & 1.6 & 6.4 \\
\hline 16/jan & 5 & 18.7 & 8.0 & 43.2 & 3 & 25.0 & 0.7 & 2.9 \\
\hline 16/jan & 5 & 17.0 & 6.1 & 35.8 & 3 & 26.4 & 0.7 & 2.6 \\
\hline 16/jan & 5 & 18.5 & 6.3 & 34.5 & 3 & 29.2 & 1.1 & 3.8 \\
\hline 16/jan & 5 & 20.2 & 6.7 & 33.6 & 3 & 31.7 & 1.6 & 5.0 \\
\hline 16/jan & 5 & 20.6 & 7.3 & 35.4 & 3 & 31.9 & 2.1 & 6.6 \\
\hline 17fjan & 5 & 25.2 & 11.2 & 44.7 & 3 & 32.7 & 2.9 & 9.0 \\
\hline 18/jan & 5 & 38.5 & 15.0 & 44.2 & 3 & 42.5 & 3.0 & 7.1 \\
\hline 20lian & 4 & 49.4 & 20.3 & 41.1 & 3 & 57.0 & 3.5 & 6.2 \\
\hline
\end{tabular}

$\mathrm{N}$ - Número de tensiómetros em funcionamento no momento da leitura.

DesPad - Desvio Padräo

CV - Coeficiente de Variação 


\subsection{Influência da temperatura sobre o comportamento do tensiômetro com manômetro de câmara de ar.}

No capítulo revisão de literatura apontamos alguns resultados experimentais (MARTHALER et al., 1983; LOWERY et al., 1986; NYHAM et al., 1987; NYHAM \& DRENNON, 1990; Van Der ELSEN \& BAKKER, 1992) mostrando o efeito que a temperatura poderia exercer sobre a resposta de sistemas tensiômetro/transdutor de pressão. No tensiômetro com manômetro de câmara de ar, para o qual a equação de cálculo do potencial mátrico (equação 3.3 ) foi originada da equação geral dos gases perfeitos (VILLA NOVA et al., 1989), a temperatura exerce influência sobre a pressão na câmara, sendo, por isso, considerada na equação. Dessa forma, a temperatura foi anotada no momento do fechamento da câmara, por ocasião do fechamento dos tensiômetros, e no momento de cada leitura.

Analisemos aqui os mesmos casos considerados no item anterior, ou seja, $15 \mathrm{~cm}$ de profundidade, blocos 1 e II, mostrados na Figura 13 . Os resultados concernentes às profundidades de 35 e $150 \mathrm{~cm}$ desses dois blocos e a duas profundidades do bloco III estăo em forma de anexos. O objetivo é evitar repetitividade, uma vez que os resultados são comparáveis aos que serão aqui descritos.

$\mathrm{Na}$ Figura 13 (a e b) tem-se as curvas de potencial mátrico com e sem correção de temperatura ao longo do tempo, a temperatura inicial (fixa, pois ela é única, do momento de fechamento do tensiômetro) e a variação da temperatura lida 
por ocasião de cada leitura da câmara de ar.

Consideremos algumas situaçōes particulares. No dia 13 de janeiro às 15 horas, onde houve a maior diferença entre a temperatura de fechamento do tensiômetro (Ti) e do momento da leitura (Tf), Figura 13.a, a saber 295 e 306K, respectivamente. A diferença entre os valores de potencial mátrico com e sem correção foi bastante elevada, da ordem de $27 \%$ (-5.7 kPa contra -7.9 kPa). Deduz-se que, nessa faixa de alto potencial mátrico, a temperatura é um aspecto fundamental a ser considerado. Quando o potencial mátrico é muito baixo a influência da temperatura não foi tão marcante. Por exemplo, no dia 20 de janeiro, quando o potencial encontrava-se abaixo de $-60 \mathrm{kPa}$, a diferença entre os valores corrigidos e não corrigidos foi da ordem de $0.6 \%$ para uma diferença de $4 \mathrm{~K}$ (295K contra 299K). Mesmo se a temperatura nesse momento fosse da mesma magnitude daquela do dia 13 de janeiro, isto é, $306 \mathrm{~K}$, a diferença entre os potenciais seria de apenas $1.6 \%$.

O resultado observado no bloco II (Figura 13.b) foi equivalente. A maior variação de temperatura foi de $13 \mathrm{~K}$, dia 16 de janeiro, promovendo diferença de $8.2 \%$ nos valores de potencial mátrico, próximo a $-30 \mathrm{kPa}$. Em potencial baixo, inferior a $-50 \mathrm{kPa}$, a diferença foi de $0.7 \%$ para uma variação de $4 \mathrm{~K}$. Caso a variação fosse a máxima, 13K, a diferença subiria para $2.3 \%$.

Desse modo, sugere-se que, quando a temperatura variar acima de, por exemplo, $10 \mathrm{~K}$ no periodo em que se monitora o potencial mátrico através de tensiômetro com manômetro de câmara de ar e o interesse reside em potenciais superiores a -10kPa, deve-se fazer a correção do potencial em 

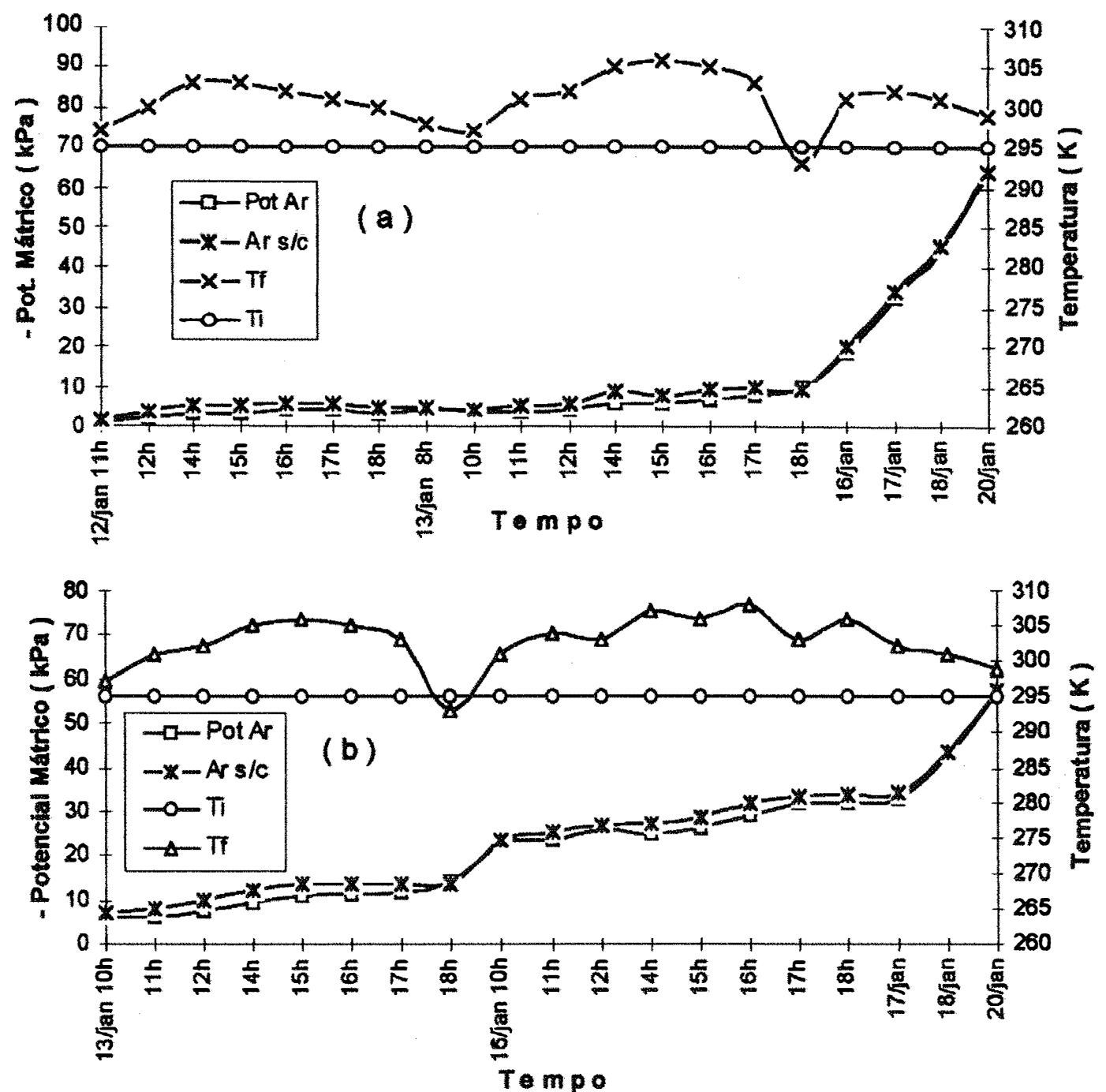

Figura 13. Potencial mátrico com e sem correçâo da temperatura e variaçăo da temperatura no experimento de campo, segundo periodo úmido. (a) bloco $1,15 \mathrm{~cm}$ e (b) bloco $11,15 \mathrm{~cm}$. 
função da temperatura. Se, por outro lado, o interesse é em potenciais inferiores, pode-se plenamente dispensar o uso de termômetros, facilitando assim as operações e diminuindo-se os custos.

\subsection{Sensibilidade do tensiômetro com manômetro de câmara de ar.}

Em qualquer instrumento que se destine a medir alguma coisa, uma das caracteristicas de fundamental importância é a sua sensibilidade. Em tensiometria, o manômetro deve ser sensivel o suficiente para detectar pequenas variações no conteúdo de água no solo próximo à sua cápsula porosa. A sensibilidade do manômetro do tensiômetro é dada pela razão entre a variação na leitura manométrica e o volume de água que passa através da cápsula porosa (quer do tensiômetro para o solo quer no sentido inverso). Assim, um manômetro é tanto mais sensivel quanto menor o volume de água que entra ou sai do tensiômetro capaz de promover uma modificação na escala de leitura que possa ser medida pelo operador.

Para se verificar a sensibilidade do tensiômetro com manômetro de câmara de ar utilizamos valores reais das dimensões do instrumento e dos potenciais obtidos nos experimentos de laboratório.

O tubo transparente do tensiômetro, no qual se lê a variação na altura da câmara de ar, tem um diâmetro interno de 
$0.952 \mathrm{~cm}$ (ver capitulo material e métodos) e, portanto, uma secção transversal de $0.712 \mathrm{~cm}^{2}$. Isto significa que a saida de $1 \mathrm{~cm}^{3}$ de água do tensiômetro para o solo acarreta numa variação de $14 \mathrm{~mm}$ na altura da câmara. Considerando-se a possibilidade de se perceber a alteração de $1 \mathrm{~mm}$ na altura da câmara, apesar das dificuldades ou possibilidades de erro já discutidas anteriormente, esta representa apenas uma variação de $0.071 \mathrm{~cm}^{3}$ de água dentro do tensiômetro. Esta seria, portanto, a menor variação no volume de água que atravessa a cápsula porosa e que poderia ser observada pelo operador.

Em termos de variação do potencial mátrico com relação à variação na altura da câmara, percebe-se pelos dados da Tabela 5 que este tipo de manômetro apresenta uma sensibilidade muito boa. Alguns valores dos dois experimentos realizados no laboratório foram utilizados para se fazer esses cálculos. A relação $\Delta \psi_{m} / \Delta h c$, total, foi feita sempre partindo de um potencial mátrico de aproximadamente zero $\left(\psi_{\mathrm{m}} \cong 0.1 \mathrm{kPa}\right)$ até o potencial considerado em cada momento. A relação parcial foi considerada entre o potencial de um determinado momento e aquele imediatamente anterior; essa variação parcial foi feita com o objetivo de se verificar se ela diferia nas diferentes faixas de potencial, visto que a relação entre o potencial mátrico e a altura da câmara năo é linear. Nota-se na Tabela 5 que a maior razão entre a variação no potencial (em $\mathrm{kPa}$ ) por milimetro de variação na altura da câmara foi de 2.5 , ou seja, aproximadamente $25 \mathrm{~cm}$ de coluna de água para a variação de leitura possivel de ser observada. Essa relaçăo, tanto a total quanto a parcial, diminui com o aumento nos 
valores de potencial. Mesmo nessa maior relação, pode-se considerar como de alta sensibilidade o manômetro de câmara de ar, visto que isso representa uma saida de água do tensiômetro para o solo de apenas $0.071 \mathrm{~cm}^{3}$, sendo que os movimentos de água entre o tensiômetro e o solo são, via de regra, de maiores magnitudes, e porque, dentro da faixa de uso do tensiômetro nas condiçőes práticas de campo, a percepção de uma variação de $2.5 \mathrm{kPa}$ no potencial já é bastante boa.

Tabela 5. Variação no potencial mátrico em função da variação na altura da câmara de ar

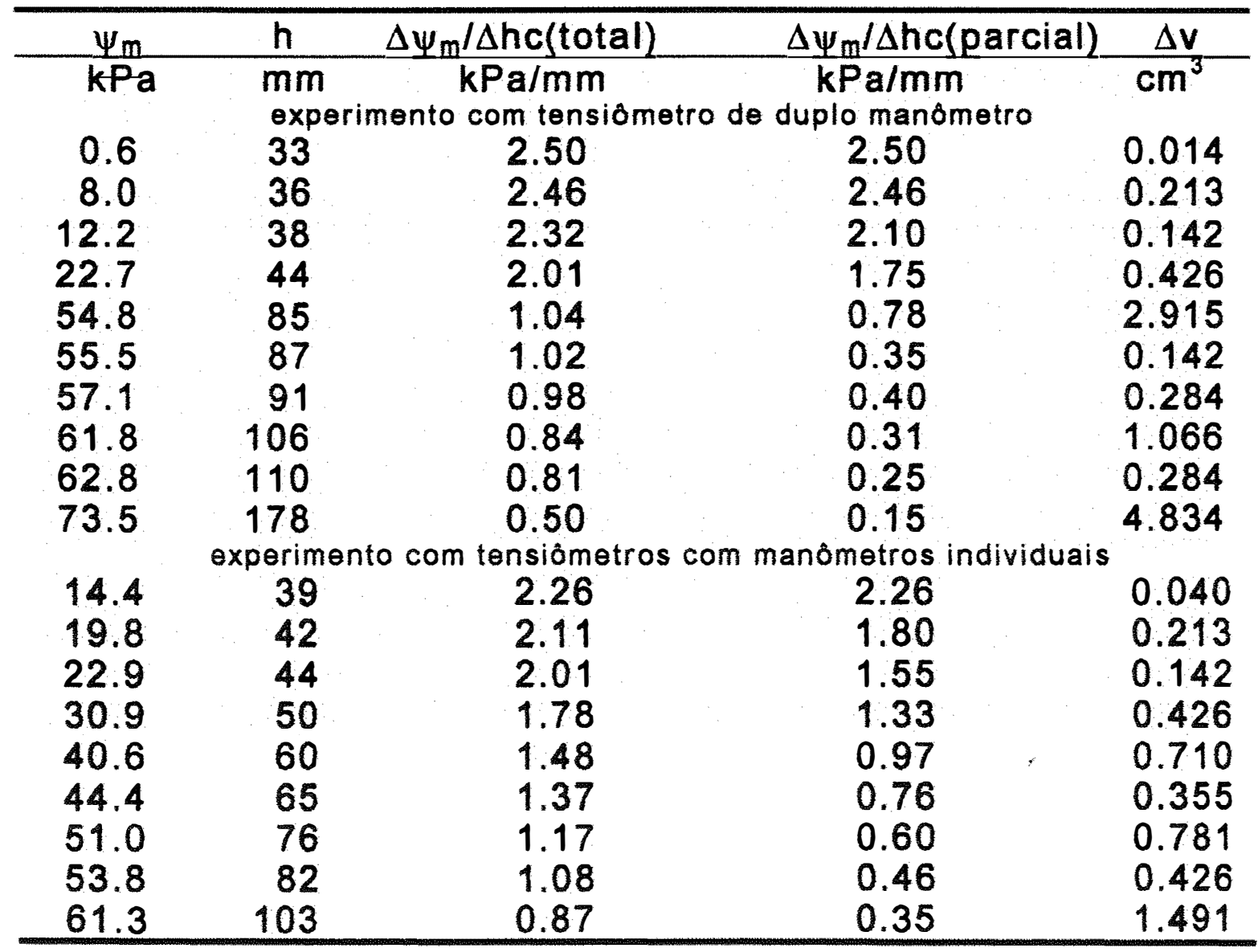

$\psi_{m}$ - potencial mátrio

$\mathrm{h}_{\mathrm{c}}$ - altura da câmara dentro do tensiómetro

$\Delta_{\mathrm{v}}$ - variação do volume de água dentro do tensiômetro 


\subsection{Consideraçōes finais.}

Os conhecimentos sobre o desempenho do tensiômetro de câmara de ar na avaliação do potencial mátrico da água ainda são bastante incipientes, devido ao fato de que esse tipo de manômetro ainda não foi suficientemente testado em condições de campo. Novos testes são necessários, sob as mais diversas condições de solo e clima, para que se possa calibrá-lo em função dos fatores que influenciam o seu comportamento.

A construção do aparelho dever ser considerada como um aspecto importante do seu desempenho. $O$ fechamento da parte superior do instrumento, no momento inicial, mostrou-se um fator de complicação durante a execução desse nosso trabalho. Acreditamos que o uso de tampa de rosca, juntamente com anel de borracha do tipo "O-ring", por nós utilizada, tenha se caracterizado como um avanço nesse sentido. A fixação da cápsula porosa e a conecção do tubo de plático transparente ao tubo de PVC devem ser feitas de modo que não possa haver entrada de ar no sistema, mesmo quando este se encontre sob altas pressōes. A marcação da câmara inicial, no tubo transparente, deve ser feita numa espessura inferior àquela do meio de medida, no nosso caso uma régua com resolução de $1 \mathrm{~mm}$.

Outro aspecto importante a ser considerado em novos estudos com o tensiômetro de cámara de ar é a introdução, na sua equação de cálculo do potencial mátrico, da pressão de vapor da água dentro da câmara. Esse fator, 
dependendo das condiçőes de temperatura, afeta sobremaneira o resultado final.

A pressão atmosférica local, como se pode perceber na equação 3.3, é fundamental na estimativa do valor de potencial mátrico da água no tensiômetro de câmara de ar. Assim sendo, deve-se ter bastante cuidado com esse aspecto, utilizando-se o seu valor correto.

Esse tipo de tensiômetro, por outro lado, e considerado o exposto acima, pode tornar-se numa ferramenta muito útil na estimativa do potencial mátrico da água no solo, por apresentar vantagens sobre o tensiômetro convencional (com manômetro de mercúrio), tais como menor custo, fácil manuseio, mais fácil manutenção e, principalmente, năo conter elemento tóxico como o mercúrio, evitando-se problemas de contaminação ambiental. 


\section{CONCLUSÕES}

Diante dos resultados obtidos nos experimentos de laboratório e de campo, pode-se concluir que o tensiômetro com manômetro de ar é uma ferramenta disponivel para uso no controle do potencial mátrico da água no solo em programas de irrigação. Para trabalhos de pesquisa, entretanto, a recomendação de seu uso talvez ainda não seja conveniente. Novos testes e análises detalhadas são ainda necessários. Um dos principais problemas durante o seu uso é o fechamento da câmara, que precisa ser perfeito, uma vez que pequenos vazamentos não facilmente perceptiveis podem levar a erros significantes de leitura.

A sensibilidade do manômetro de cámara de ar pode ser considerada como muito boa, não se constituindo, portanto, em um problema para o seu uso, desde que as leituras sejam feitas com bastante cuidado.

Pequenas variações na temperatura não influenciam nas respostas do tensiômetro de cámara de ar. Em regióes onde a temperatura não varia muito durante o ciclo de uma determinada cultura pode-se dispensar o uso de termômetros, diminuindo-se o trabalho do operador, bem como os custos de cultivo. 


\section{REFERÊNCIAS BIBLIOGRÁFICAS}

AUGUSTIN, B. J. \& SNYDER, G. H. Moisture sensor-controlled irrigation for maintaining bermudgrass turf. Agronomy Journal, Madison, 76 (5): 848-850, 1984.

AZOOZ, R. H. $\&$ ARSHAD, M. A. Laboratory calibration of pressure transducer-tensiometer system for hydraulic studies. Canadlan Journal Soil Science, Ottawa, 74: 315$319,1994$.

BEZERRA, F. M. L. Coeficientes de cultura e efeitos de déficits hídricos nos diferentes estádios fenológicos sobre a produção da batata (Solanum tuberosum L.). Piracicaba, 1995. 131p. Tese (doutorado) - Escola Superior de Agricultura "Luiz de Queiroz", Universidade de Săo Paulo.

BLACK, C. A. Soil-Plant Relationships. 2.ed. New york, John Wiley \& Sons, 1968. 792p.

BOOLTINK, H. W. $\varepsilon$ BOUMA, J. Physical and morfological characterization of bypass flow in a well-structured clay soil. Soil Science Society American Journal, Madison, 55 (5): 1249-1254, 1991.

CAMARGO, A. P.; GROHMAN, F. $\varepsilon$ CAMARGO, M. B. P. Tensiômetro simples de leitura direta. Pesquisa 
Agropecuária Brasileira, Brasília, 17 (12): 1763-1772, 1982.

CAMPBELL, G. S. Overview: soil water potential measurement. in: INTERNATIONAL CONFERENCE ON MEASUREMENT OF SOIL AND PLANT WATER STATUS, 1, Logan, 1987. Proceedings. Logan, 1987, p. 115-118.

CRESSWELL, H. P. Evaluation of the portable pressure transducer technique for measuring field tensiometers. Australian Journal Soil Research, Melbourne, 31: $397-$ 406, 1993.

DEXTER, A. R. Changes in the matric potential of soil water with time after disturbance of soil by moulding. Soil \& Tillage Research, Amsterdam, 16 (1-2): 35-50, 1990.

GAUSSOIN, R. G.; MURPHY, J. A. \& BRANHAM, B. E. A vertically installed, flush mounted tensiometer for turfgrass research. HortScience, Alexandria, 25 (8): 928-929, 1990. HENDRICKX, J. M. H. \& WIERENGA, P. J. Variability of soil water tension in a trickle irrigated Chile pepper field. Irrigation Science, New York, 11 (1): 23-30, 1990.

HENDRICKX, J. M. H.; NIEBER, J. L. \& SICCAMA, P. D. Effect of tensiometer cup size on field soil water tension variability. Soil Science Society American Journal, Madison, 58 (2): 309-315, 1994.

HODNET, M. G.; BELL, J. P.; AH KOON, P. D.; SOOPRAMANIEN, G. C. \& BATCHELOR, C. H. The control of drip irrigation of sugarcane using "index" tensiometers: some comparisons with control by water budget method. 
Agricultural Water Manegement, Amsterdam, 17 (1-3): 189-207, 1990.

HOOK, J. E. Tensiometers in irrigation research. in: INTERNATIONAL CONFERENCE ON MEASUREMENT OF SOIL AND PLANT WATER STATUS, 1, Logan, 1987. Proceedings. Logan, 1987, p. 163-168.

KLUTE, A. \& GARDNER, W. R. Tensiometer response time. Soil Science, Baltimore, 93 (1): 204-207, 1962.

KLUTE, A. $\varepsilon$ PETERS, D. B. A recording tensiometer with a short response time. Soil science society of America Proceedings, Madison, 26 (1): 87-88, 1962.

LAMBERT, J. R.; DOTY, C. W. $\varepsilon$ QUISENBERRY, V. L. Irrigation scheduling in humid areas. in: PROCEEDINGS OF IRRIGATION SCHEDULING CONFERENCE, Chicago, dec, 1981. Proceedings of the American Society of Agricultural Engineers, St. Joseph, 1981, p. 132-143.

LONG, F. L. A new solid-state device for reading tensiometers. Soil Science, Baltimore, 133 (2): 131-132, 1982.

LONG, F. L. A field system for automatically measuring soil water potential. Soil Science, Baltimore, 137 (4): 227-230, 1984.

LOWERY, B.; DATIRI, B. C. $\varepsilon$ ANDRASKI, B. J. An electrical readout system for tensiometers. Soil Science Society American Journal, Madison, 50 (2): 494-496, 1986.

MARTHALER, H. P.; VOGELSANGER, W.; RICHARD, F. $\varepsilon$ WIERENGA, P. J. A pressure transducer for field tensiometers. Soll Science Society American Journal, Madison, 47 (4): 624-627, 1983. 
MORRISON, R. D. \& SZECSODY, J. E. A tensiometer and pore water sampler for vadoze zone monitoring. Soil Science, Baltimore, 144 (5), 367-372, nov. 1987.

MULLINS, C. E.; MANDIRINGANA, O. T.; NISBENT, T. R. $\varepsilon$ AITKEN, M. N. The design, limitations, and use of a portable tensiometer. Journal of Soil Science, Oxford, 37 : $691-700,1986$.

NYHAN, J. W. \& DRENNON, B. J. Tensiometer data acquisition system for hydrologic studies requiring high temporal resolution. Soil Science Society American Journal, Madison, 54 (1): 293-296, 1990.

NYHAN, J. W.; DRENNON, B. J. $\varepsilon$ GAYLOR, R. M. Field evolution of a tensiometer data acquisition system for hydrologic studies of waste disposal site design. in: INTERNATIONAL CONFERENCE ON MEASUREMENT OF SOIL AND PLANT WATER STATUS, 1, Logan, 1987. Proceedings. Logan, 1987. p. 145-150.

OLITTA, A. F. Construção de tensiômetros para controle de irrigação. O Solo, Piracicaba, 68 (2): 16-20, 1976.

PECK, A. J. \& RABBIDGE, R. M. Soil-water potential: direct measurement by a new technique. Science, Washington, 151:1385-1386, 1966.

POOLEY, S. G. Tensiometers in irrigated agriculture. in: WINTER MEETING OF AMERICAN SOCIETY OF AGRICULTURAL ENGINEERS, Chicago, 1973. American Society of Agricultural Engineers. St. Joseph,1973, p.1-4. 
REICHARDT, K. Processos de transferência no Sistema Solo-Planta-Atmosfera. 4.ed. Campinas, Fundação Cargill, 1985. 445p.

REICHARDT, K. A Água em Sistemas Agricolas. 1.ed. São Paulo, Editora Manole Ltda, 1990. 188p.

RICE, R. A fast-response, field tensiometer system. Transactions of the American Society of Agricultural Engineers, St. Joseph, 1969, p. 48-50.

RICHARDS, L. A. $\varepsilon$ NEAL, O. R. Some field observations with tensiometers. Proceodings of Soil Science Society America, Madison, 1:71-91, 1936.

SINGH, P. V.; PAL, D.; VARADE, S. B. \& KAR, S. Determining percolation losses of packed clay soil from tensiometer data. Agricultural Water Management, Amsterdam, 15: 189-195, 1988.

SMAJSTRLA, A. G. $\varepsilon$ KOO, R. C. Use of tensiometers for scheduling of citrus trickle irrigation. Proceeding of the Florida State Horticulture Society. Miami Beach, 99: 51$56,1986$.

SMAJSTRLA, A. G. \& LOCASCIO, S. J. Irrigation scheduling of drip-irrigated tomato using tensiometers and pan evaporation. Proceedings of the Florida State Horticulture Society, Miami Beach, 103: 88-91, 1990.

TAMARI, S.; GUADU, J. C. $\varepsilon$ SIMONNEAU, T. Tensiometric measurement and metastable state of water under tension. Soil Science, Baltimore, 156 (3): 149-155, 1993. 
TAYLOR, S. A. Use of mean soil moisture evaluate the effect of soil moisture on crops yields. Soil Science, Baltimore, 74 : 217-226, 1952.

TAYLOR, S.A. Managing irrigation water on the farm. Transaction of the ASAE, St. Joseph, 8(3): 433-436, 1965. THIEL, T. J.; FOUSS, J. L. \& LEECH, A. P. Electrical water pressure transducers for field and laboratory use. Soil Science Society of America Proceedings, Madison, 27 (5): 601-602, 1963.

THOMAS, G. W. $\varepsilon$ PHILLIPS, R. E. The transient instability of tensiometer readings during infiltration. Soil Science, Baltimore, 152 (3); 231-235, 1991.

TOKUNAGA, T. The pressure response of the soil water sampler and possibilities for simultaneous soil solution. Soil Science, Baltimore, 154 (3): 171-183, 1992.

TOKUNAGA, T. $\varepsilon$ SALVE, R. Gauge sensivity optimization in air pocket tensiometry: implications for deep vadoze zone monitoring. Soil Science, Baltimore, 158 (6): 389-397, 1994.

TOWNER, G. D. Theory of time response of tensiometers. Journal of Soil Science, Oxford, 31: 607-621, 1980.

TOWNER, G. D. A method for improving cheaply the time response of pressure-transducer tensiometer system. Agricultural Water Management, Amsterdam, 5: 285-293, 1982.

TROTTER, C. M. Errors in reading tensiometer vacua with pressure transducers. Soil Science, Baltimore, 138 (4): 314-316, oct. 1984. 
Van Der ELSEN, H. G. M. \& BAKKER, J. W. A universal device to measure to pressure head for laboratory use or long-term stand-alone field use. Soil Science, Baltimore, 54: 458464, 1992.

VILLA NOVA, N. A.; REICHARDT, K.; LIBARDI, P. L. $\varepsilon$ MORAES, S. O. Direct reading "air-pocket" tensiometer. Soil Tecchnology, Cremlingen, 2: 403-407, 1989.

VILLA NOVA, M. S.; VILLA NOVA, N. A.; OLIVEIRA, A. S. $\varepsilon$ REICHARDT, K. Performance and test of a direct reading "air-pocket" tensiometer. Short Communication, Cremlinger, 5: 283-287, 1992.

VILLAGRA, M. M.; MATSUMOTO, O. M.; BACCHI, O. O. S.; MORAES, S. O.; LIBARDI, P. L. $\varepsilon$ REICHARDT, K. Tensiometria e variabilidade espacial em terra roxa estruturada. Revista Brasileira de Ciência do Solo, Campinas, 12: 205-210, 1988.

WATSON, K. K. Response behavior of a tensiometer-pressure transducer system under conditions of changing pore air pressure. Soil Science, Baltimore, 104 (6): 439-443, 1967. WATSON, K. K. $\varepsilon$ JACKSON, R. D. Temperature effects in a tensiometer-pressure transducer system. Soil Science Society of America Proceedlngs, Madison, 31:156160, 1967

WERKHOVEN, C. Sensors for irrigation scheduling of cultures in the field. Acta-Horticulturae, Wageningen, 304: 259264, jan, 1992.

WIERENGA, P. J.; FOWLER, J. L. \& DAVIS, D.D. Use of tensiometers for scheduling drip-irrigated cotton. IN: 
INTERNATIONAL CONFERENCE ON MEASUREMENT OF SOIL AND PLANT WATER STATUS, 1, Logan, 1987, PROCEEDINGS. Logan, 1987. p. 157-161. 
Apêndices 
Apéndice 1 - Média, desvio padrão e coeficiente de variação dos valores de potencial mátrico obtidos por tensiómetro de mercúrio e de câmara de ar, bloco $1-35 \mathrm{~cm}$ de profundidade.

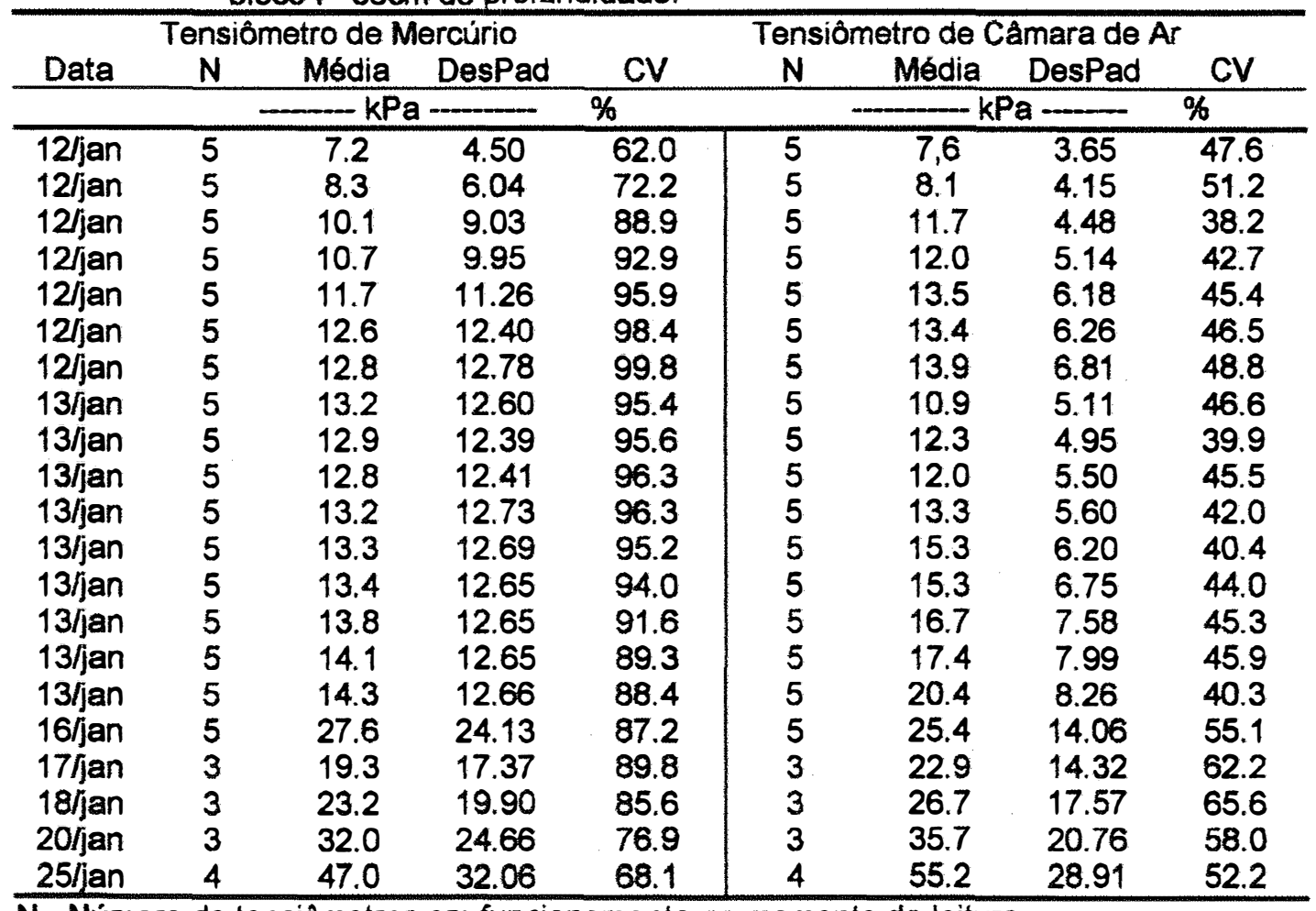

$\mathrm{N}$ - Número de tensiómetros em funcionamento no momento da leitura.

DesPad - Desvio Padrão

CV - Coeficiente de Variação 

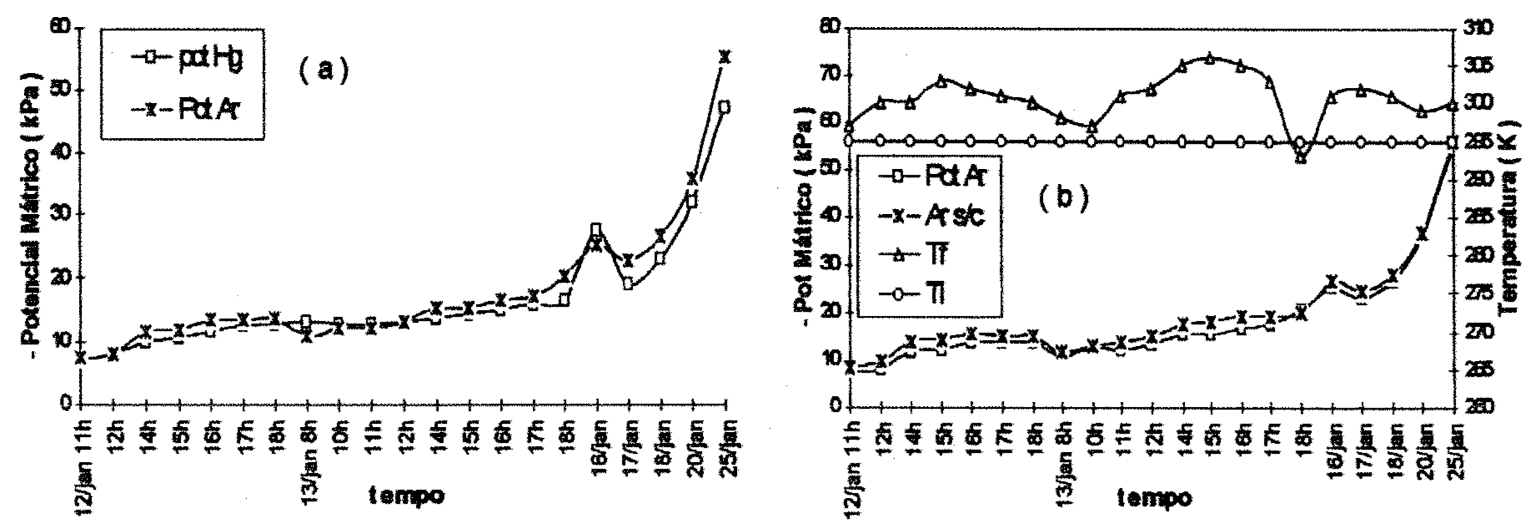

Apéndice 2 - Potencial mátrico versus tempo no experimento de campo, bloco I, $35 \mathrm{~cm}$ de profundidade. (a) tensiômetro convencional $x$ tensiómetro de câmara de ar; (b) tensiómetro de câmara de ar com e sem correçăo de temperatura.

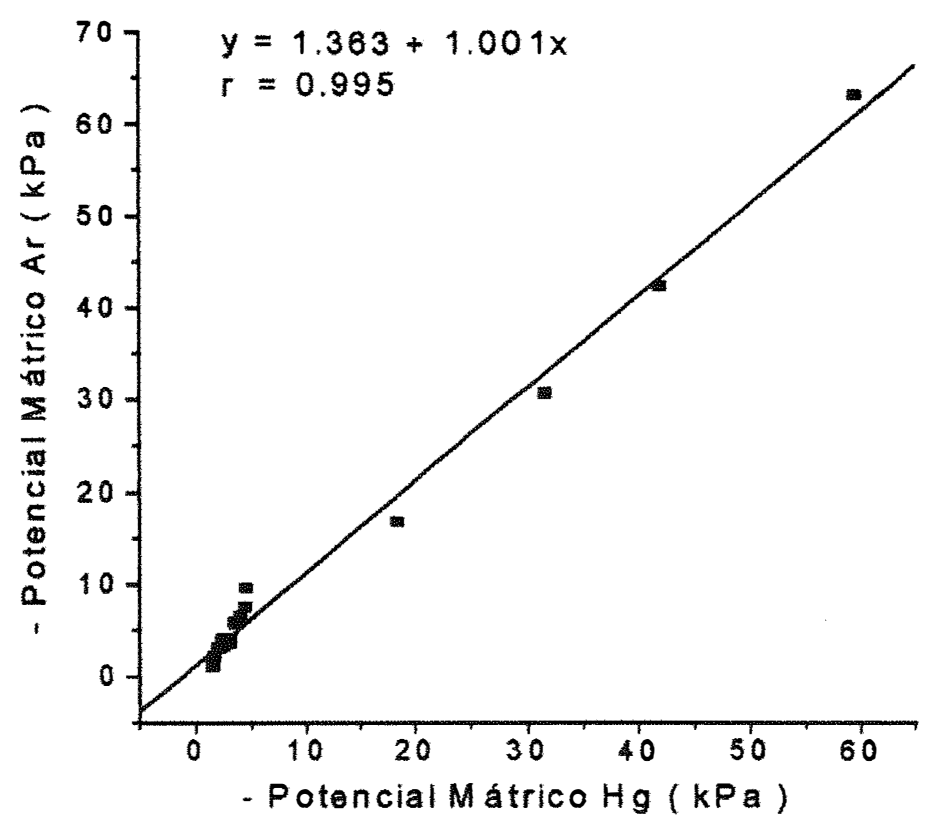

Apéndice 3 - Relação entre potencial mátrico obtido por tensiômetro convencional e de cámara de ar, experimento de campo, bloco I, $35 \mathrm{~cm}$, segundo período úmido. 
Apêndice 4 - Média, desvio padrão e coeficiente de variação dos valores de potencial mátrico obtidos por tensiômetro de mercúrio e de cámara de ar, bloco $1-150 \mathrm{~cm}$ de profundidade.

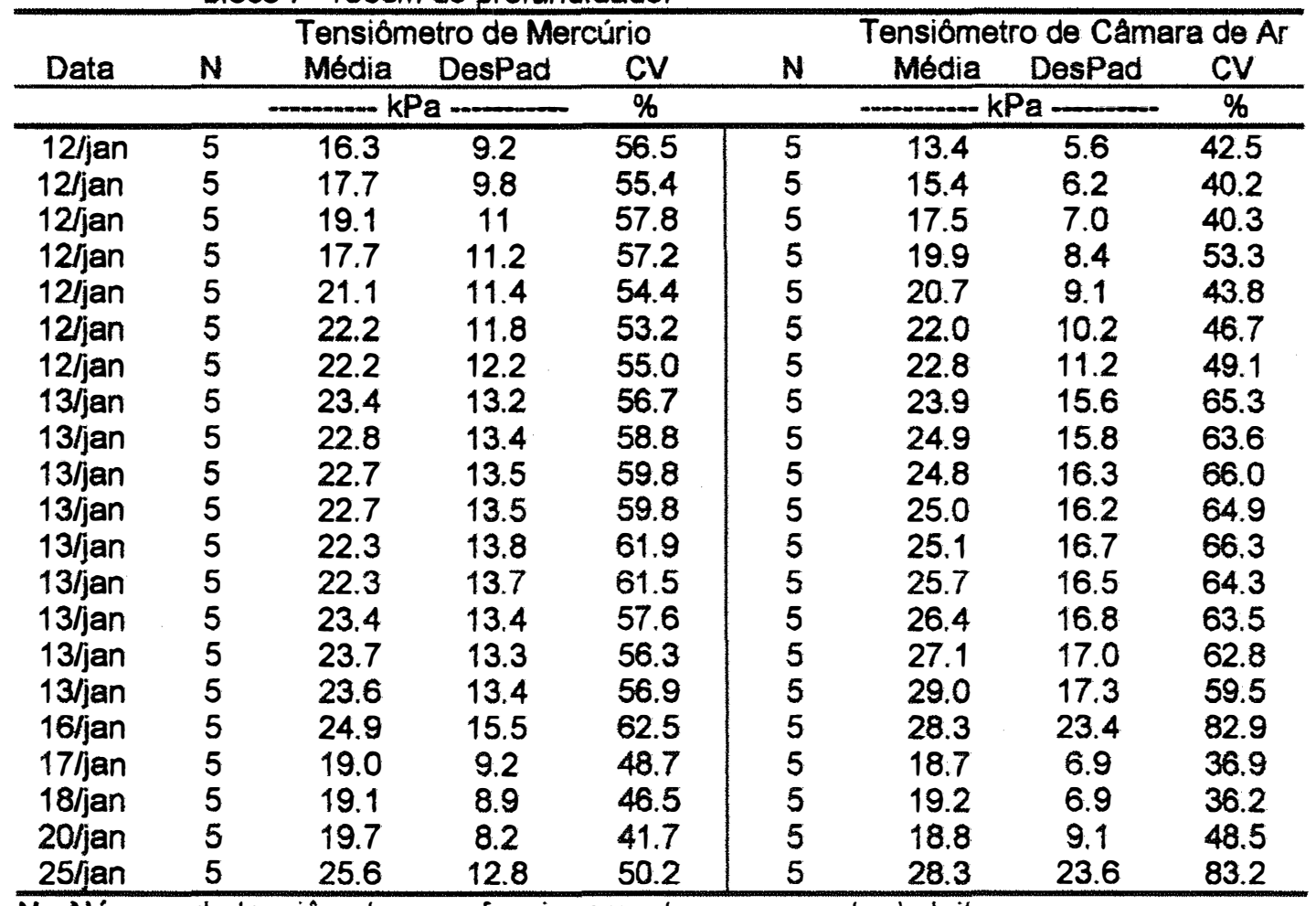

$\mathrm{N}$ - Número de tensiómetros em funcionamento no momento da leitura.

DesPad - Desvio Padrăo

CV - Coeficiente de Variaçăo 

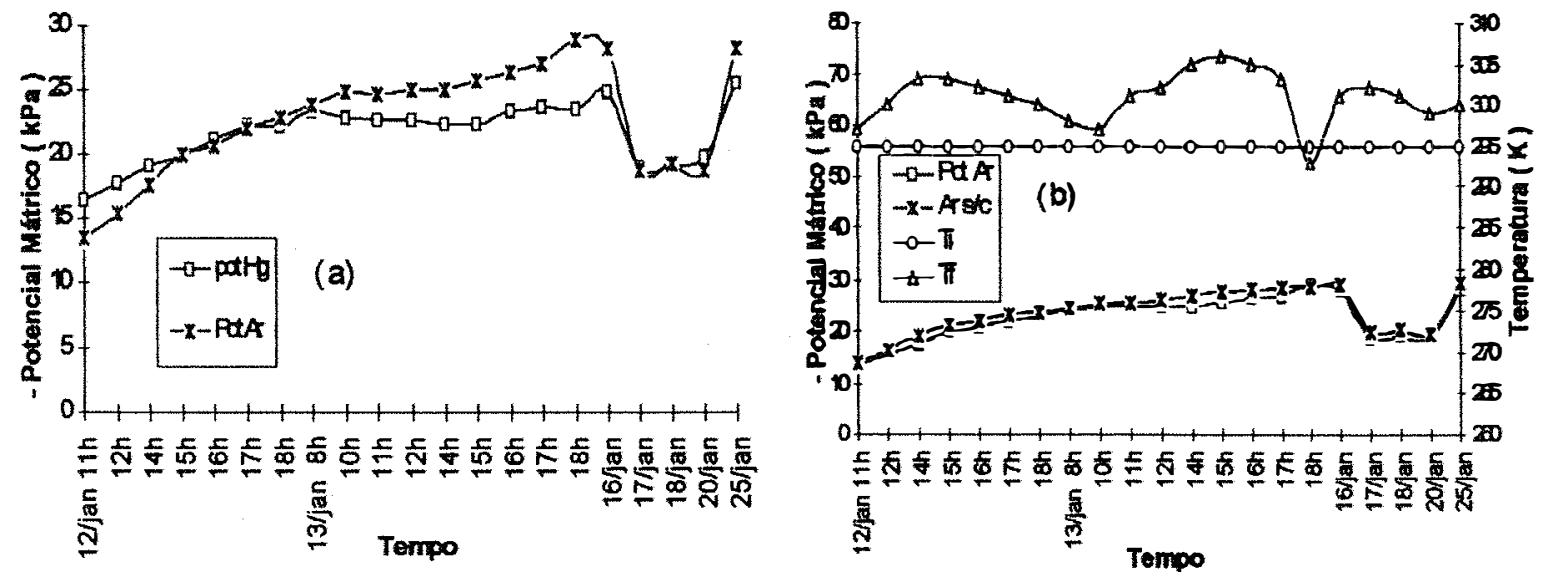

Apêndice 5 - Potencial mátrico versus tempo, experimento de campo, bloco I, $150 \mathrm{~cm}$ de profundidade. (a) tensiómetro convenciona x tensiómetro de cámara de ar; (b) tensiómetro de cámara de ar com e sem correção da temperatura, segundo periodo úmido.

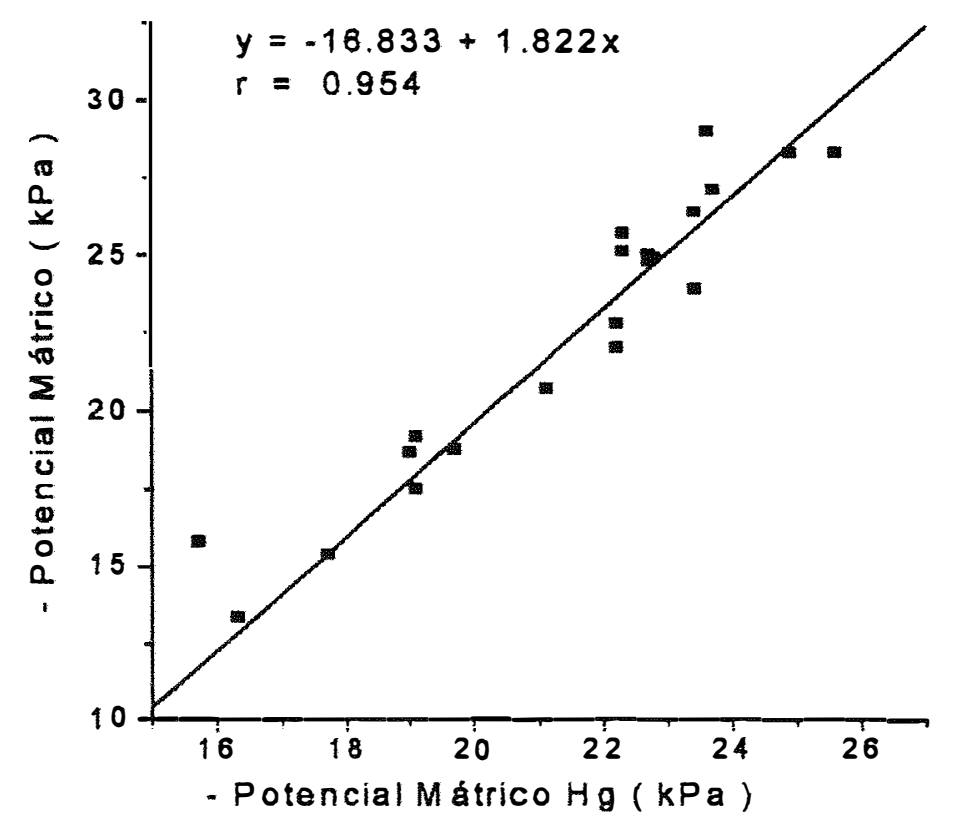

Apêndice 6 - Relação entre potencial mátrico obtido por tensiômetro convencional e de câmara de ar, experimento de campo, bloco I, $150 \mathrm{~cm}$, segundo periodo úmido. 
Apêndice 7 - Média, desvio padrão e coeficiente de variação dos valores de potencial mátrico obtidos por tensiómetro de mercúrio e de cámara de ar, bloco 11 - $35 \mathrm{~cm}$ de profundidade.

\begin{tabular}{|c|c|c|c|c|c|c|c|c|}
\hline \multirow[b]{2}{*}{ Data } & \multicolumn{4}{|c|}{ Tensiómetro de Mercúrio } & \multirow[b]{2}{*}{$\mathbf{N}$} & \multicolumn{3}{|c|}{ Tensiómetro de Cámara de Ar } \\
\hline & $\mathbf{N}$ & Média & DesPad & $\mathrm{CV}$ & & Média & DesPad & CV \\
\hline & & $-k$ & a - & $\%$ & & 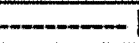 & $a$ & $\%$ \\
\hline 13/jan & 4 & 2.9 & 0.7 & 23.5 & 5 & 3.3 & 1.9 & 57.0 \\
\hline 13/jan & 4 & 3.4 & 0.7 & 22.9 & 5 & 4.5 & 1.6 & 36.7 \\
\hline 13/ian & 4 & 3.5 & 0.9 & 26.7 & 5 & 5.6 & 1.6 & 30.2 \\
\hline $13 / j a n$ & 4 & 4.0 & 1.1 & 28.1 & 5 & 6.5 & 1.2 & 18.7 \\
\hline $13 /$ ian & 4 & 4.2 & 1.2 & 28.9 & 5 & 7.8 & 2.7 & 34.6 \\
\hline 13/ian & 4 & 4.5 & 1.5 & 34.5 & 5 & 8.5 & 2.1 & 25.4 \\
\hline 13/jan & 4 & 4.8 & 1.8 & 39.0 & 5 & 9.0 & 2.1 & 23.8 \\
\hline 13/jan & 4 & 5.0 & 1.9 & 38.9 & 5 & 8.9 & 5.0 & 56.2 \\
\hline 16/jan & 4 & 8.3 & 3.1 & 37.9 & 5 & 9.8 & 3.3 & 33.8 \\
\hline 16fian & 4 & 8.2 & 2.8 & 34.8 & 5 & 10.7 & 2.6 & 24.6 \\
\hline 16/jan & 4 & 8.1 & 2.6 & 31.8 & 5 & 12.0 & 3.2 & 27.3 \\
\hline 16/jan & 4 & 8.7 & 3.1 & 36.2 & 5 & 12.5 & 2.9 & 23.3 \\
\hline 16/jan & 4 & 8.9 & 3.0 & 34.4 & 5 & 14.6 & 4.5 & 31.4 \\
\hline 16/jan & 4 & 9.4 & 3.4 & 37.0 & 5 & 14.5 & 4.0 & 27.8 \\
\hline 16/jan & 4 & 10.3 & 4.1 & 39.9 & 5 & 15.6 & 4.8 & 31.2 \\
\hline 16fjan & 4 & 10.0 & 3.8 & 38.2 & 5 & 15.2 & 4.9 & 32.3 \\
\hline 17fian & 4 & 11.4 & 4.9 & 43.6 & 5 & 12.5 & 3.6 & 28.9 \\
\hline 18/jan & 4 & 13.8 & 6.2 & 45.0 & 5 & 14.4 & 4.7 & 33.1 \\
\hline 20/ian & 4 & 20.4 & 10.2 & 49.9 & 4 & 16.7 & 5.2 & 31.5 \\
\hline
\end{tabular}

$\mathrm{N}$ - Número de tensiómetros em funcionamento no momento da leitura.

DesPad - Desvio Padrão

CV - Coeficiente de Variação 

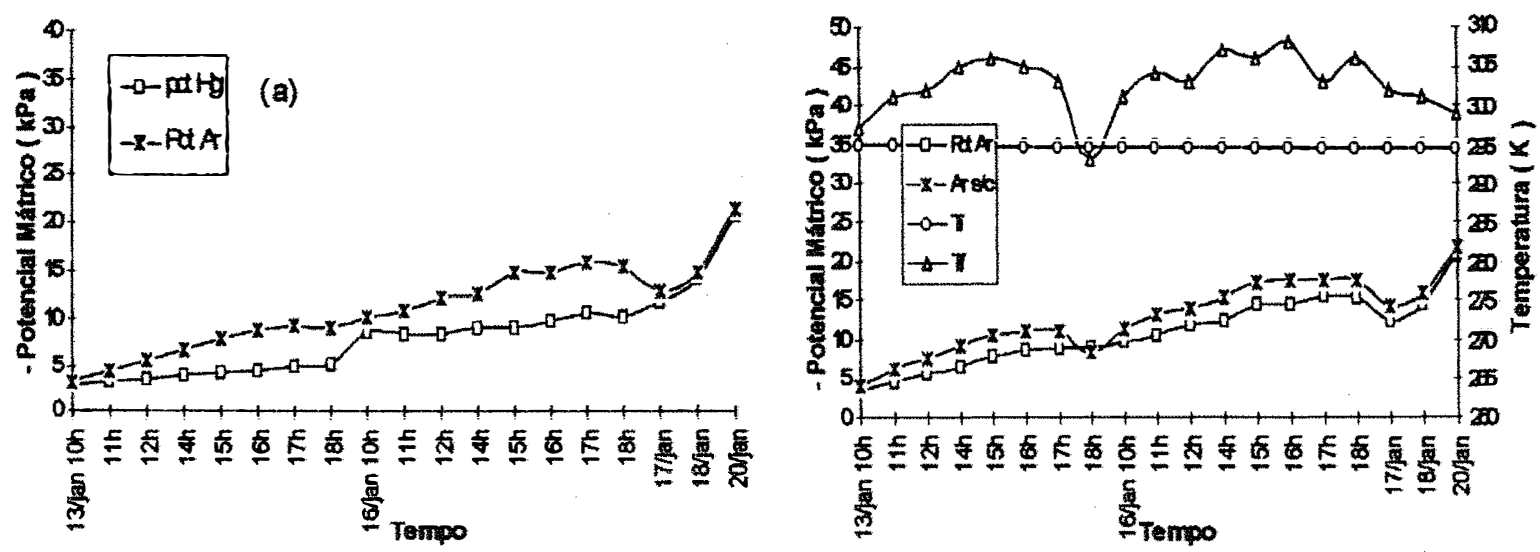

Apéndice 8 - Potencial mátrico versus tempo, experimento de campo, bloco $11,35 \mathrm{~cm}$ de profundidade. (a) tensiómetro convencional $x$ tensiómetro de cámara de ar; (b) tensiómetro de cámara de ar com e sem correçăo de temperatura, segundo período úmido.

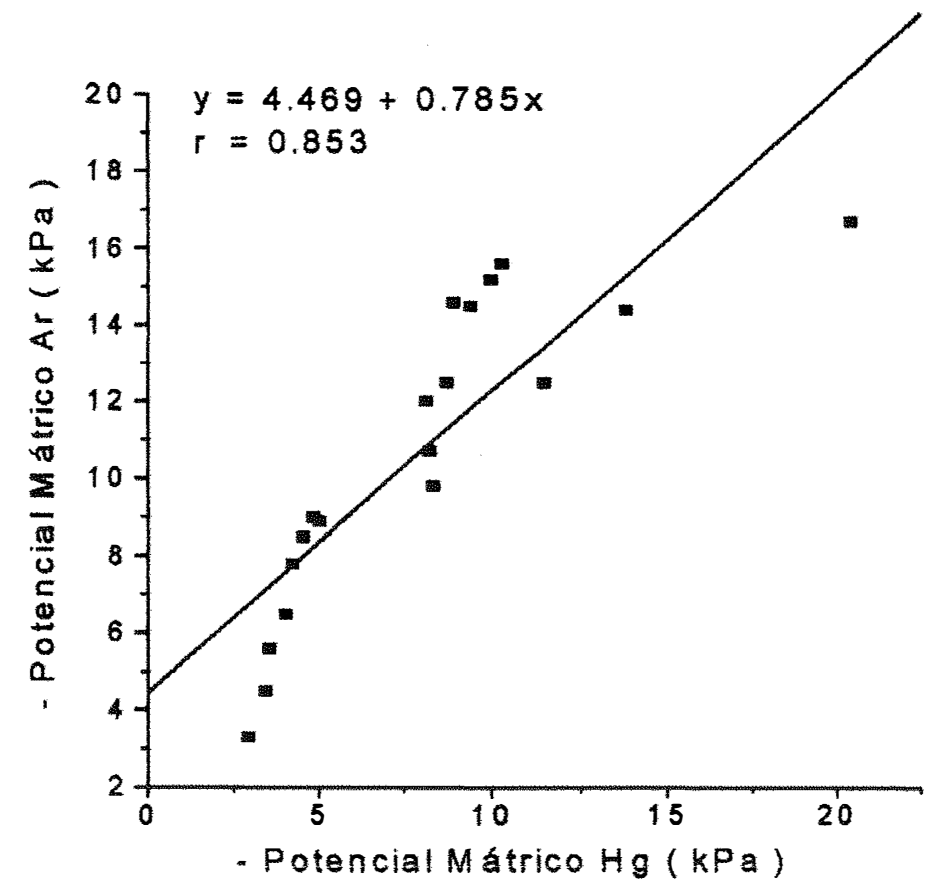

Apêndice 9 - Relação entre potencial mátrico obtido por tensiómetro convencional e de câmara de ar, experimento de campo, bloco II, $35 \mathrm{~cm}$, segundo período úmido. 
Apéndice 10 - Média, desvio padräo e coeficiente de variação dos valores de potencial mátrico obtidos por tensiómetro de mercúrio e de câmara de ar, bloco II $-150 \mathrm{~cm}$ de profundidade.

\begin{tabular}{|c|c|c|c|c|c|c|c|c|}
\hline \multirow[b]{2}{*}{ Data } & \multicolumn{4}{|c|}{ Tensiómetro de Mercúrio } & & \multicolumn{3}{|c|}{ Tensiómetro de Câmara de Ar } \\
\hline & $\mathbf{N}$ & Média & DesPad & CV & $\mathbf{N}$ & Média & DesPad & CV \\
\hline & & $\ldots-1$ & $a \ldots$ & $\%$ & & $\cdots$ & $a$ & $\%$ \\
\hline $13 / \mathrm{jan}$ & 5 & 10.7 & 2.3 & 20.7 & 5 & 12.8 & 1.2 & 10.1 \\
\hline 13/ian & 5 & 12.2 & 0.7 & 6.3 & 5 & 14.2 & 2.1 & 15.4 \\
\hline 13/jan & 5 & 12.9 & 1.7 & 13.4 & 5 & 14.7 & 2.7 & 18.4 \\
\hline 13/jan & 5 & 13.4 & 3.0 & 22.4 & 5 & 16.4 & 2.5 & 15.5 \\
\hline 13/jan & 5 & 13.8 & 2.9 & 21.6 & 5 & 16.8 & 2.7 & 16.3 \\
\hline 13/jan & 5 & 14.1 & 3.2 & 23.0 & 5 & 17.4 & 3.0 & 17.4 \\
\hline 13/jan & 5 & 14.4 & 3.5 & 24.4 & 5 & 17.6 & 3.0 & 17.6 \\
\hline 16/jan & 5 & 14.5 & 3.6 & 24.9 & 5 & 19.6 & 2.9 & 14.8 \\
\hline 16/jan & 5 & 14.4 & 2.8 & 19.8 & 5 & 14.4 & 2.4 & 16.7 \\
\hline 16/jan & 5 & 14.4 & 2.7 & 19.3 & 5 & 14.0 & 2.7 & 19.6 \\
\hline 16/jan & 5 & 14.3 & 2.6 & 18.3 & 5 & 15.4 & 2.6 & 17.1 \\
\hline 16/jan & 5 & 14.4 & 2.5 & 17.5 & 5 & 16.8 & 2.8 & 17.0 \\
\hline 16/jan & 5 & 14.6 & 2.3 & 16.3 & 5 & 17.5 & 2.3 & 13.5 \\
\hline 16/jan & 5 & 14.6 & 2.2 & 15.6 & 5 & 17.1 & 2.3 & 13.9 \\
\hline 16/jan & 5 & 15.3 & 2.5 & 16.9 & 5 & 18.4 & 2.6 & 14.6 \\
\hline 16/jan & 5 & 14.9 & 2.6 & 17.4 & 5 & 17.9 & 1.9 & 11.0 \\
\hline 17ljan & 5 & 14.6 & 2.5 & 17.5 & 5 & 16.2 & 2.4 & 17.0 \\
\hline 18fjan & 5 & 15.0 & 2.4 & 16.2 & 5 & 15.2 & 2.5 & 19.0 \\
\hline 20lian & 5 & 15.5 & 2.2 & 14.3 & 5 & 15.1 & 2.7 & 21.3 \\
\hline
\end{tabular}

$\mathrm{N}$ - Número de tensiómetros em funcionamento no momento da leitura.

DesPad - Desvio Padrảo

CV - Coeficiente de Variação 

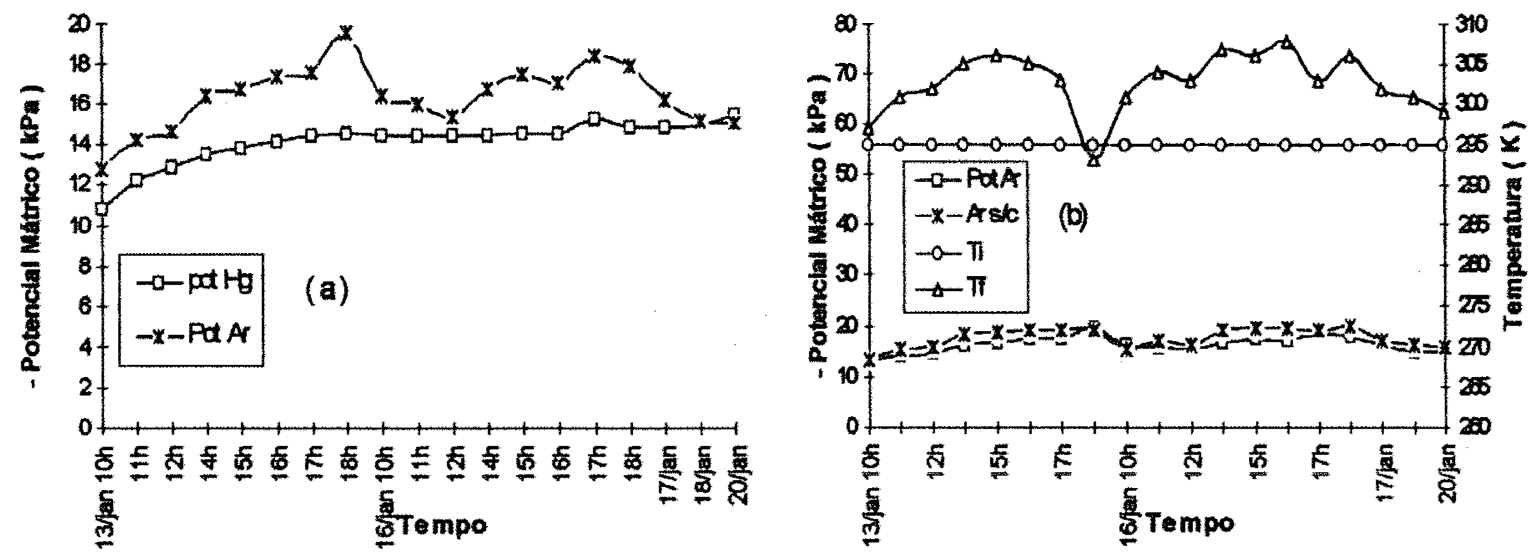

Apéndice 11 - Potencial mátrico versos tempo, experimento de campo, bloco $11,150 \mathrm{~cm}$ de profundidade. (a) tensiómetro convencional $x$ tensiómetro de cámara de ar; (b) tensiômetro de câmara de ar com e sem correçăo de temperatura, segundo período úmido.

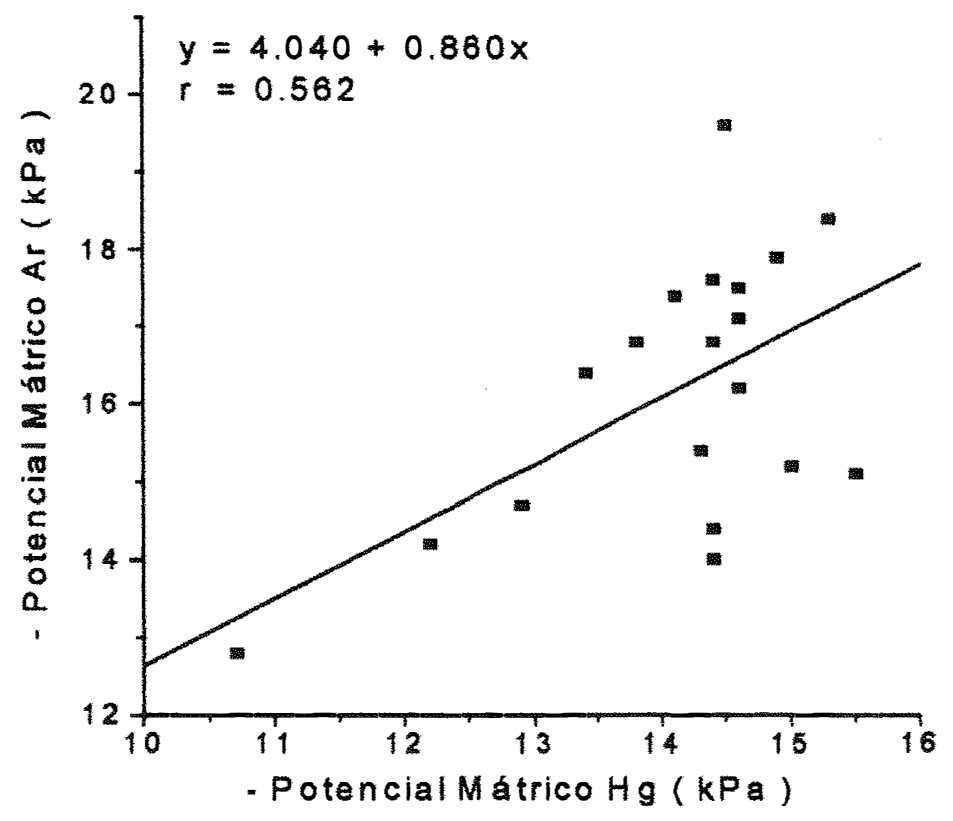

Apéndice 12 - Relação entre potencial mátrico obtido por tensiômetros convencional e de câmara de ar, experimento de campo, bloco $11,150 \mathrm{~cm}$, segundo período úmido 
Apéndice 13 - Média, desvio padrão e coeficiente de variação dos valores de potencial mátrico obtidos por tensiômetro de mercúrioe de câmara de ar, bloco III $-15 \mathrm{~cm}$ de profundidade.

\begin{tabular}{|c|c|c|c|c|c|c|c|c|}
\hline \multirow[b]{2}{*}{ Data } & \multicolumn{4}{|c|}{ Tensiômetro de Mercúrio } & \multirow[b]{2}{*}{$\mathrm{N}$} & \multicolumn{3}{|c|}{ Tensiômetro de Câmara de $\mathrm{A}$} \\
\hline & $\mathbf{N}$ & Média & DesPad & CV & & Média & DesPad & CV \\
\hline & & \multicolumn{2}{|c|}{$\mathrm{kPa}$} & $\%$ & & \multicolumn{2}{|c|}{$\mathrm{kPa}$} & $\%$ \\
\hline 16/jan & 5 & 6.1 & 2.4 & 39.4 & 5 & 10.1 & 1.4 & 13.8 \\
\hline 16/jan & 5 & 7.3 & 2.0 & 28.6 & 5 & 9.8 & 0.8 & 8.6 \\
\hline 16/jan & 5 & 10.8 & 7.7 & 71.9 & 5 & 13.1 & 1.5 & 12.0 \\
\hline 16/jan & 5 & 8.8 & 3.0 & 34.7 & 5 & 16.5 & 2.3 & 14.3 \\
\hline 16/jan & 5 & 10.2 & 3.6 & 35.1 & 5 & 19.1 & 3.4 & 17.8 \\
\hline 16/jan & 5 & 10.2 & 3.7 & 36.5 & 4 & 17.0 & 2.9 & 17.1 \\
\hline 16/jan & 5 & 11.4 & 4.4 & 39.1 & 4 & 19.3 & 3.0 & 15.8 \\
\hline 16/jan & 5 & 11.2 & 4.3 & 38.6 & 4 & 18.7 & 3.0 & 16.5 \\
\hline 17/jan & 5 & 14.1 & 5.2 & 37.4 & 4 & 17.2 & 2.8 & 16.8 \\
\hline 17rjan & 5 & 14.4 & 5.5 & 38.4 & 4 & 17.9 & 2.8 & 16.0 \\
\hline 17fjan & 5 & 14.9 & 5.5 & 37.1 & 4 & 18.9 & 3.4 & 18.1 \\
\hline 17/jan & 5 & 17.5 & 5.4 & 30.8 & 4 & 21.3 & 3.2 & 15.0 \\
\hline 17/jan & 5 & 17.6 & 6.4 & 36.6 & 4 & 19.6 & 3.5 & 18.2 \\
\hline 17/jan & 5 & 16.4 & 8.4 & 51.7 & 4 & 20.1 & 3.5 & 17.7 \\
\hline 17/jan & 5 & 18.0 & 6.7 & 37.4 & 4 & 20.7 & 4.0 & 19.5 \\
\hline 18/jan & 5 & 18.7 & 8.1 & 43.6 & 4 & 20.5 & 3.9 & 19.1 \\
\hline 20/jan & 5 & 32.3 & 13.7 & 42.6 & 4 & 28.7 & 9.2 & 32.2 \\
\hline
\end{tabular}

$\mathrm{N}$ - Número de tensiómetros em funcionamento no momento da leitura.

DesPad - Desvio Padrão

CV - Coeficiente de Variação 

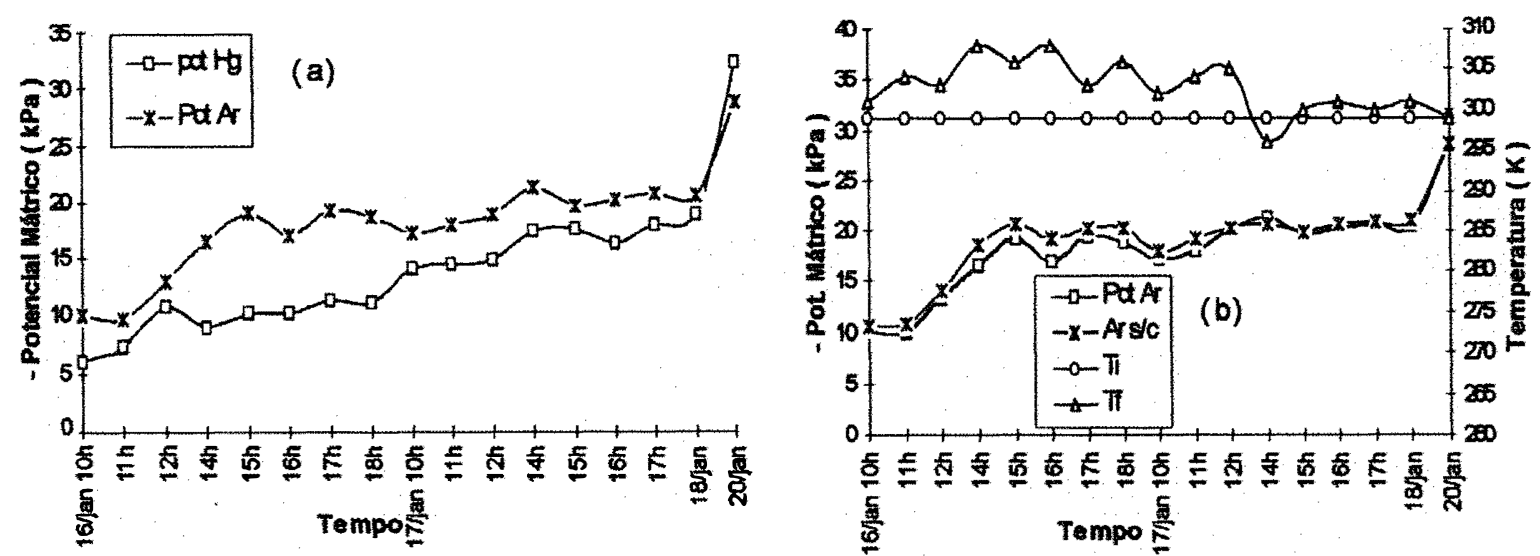

Apéndice 14 - Potencial mátrico versus tempo, experimento de campo, bloco III, $15 \mathrm{~cm}$ de profundidade. (a) tesniómetro convencional $x$ tensiómetro de cámara de ar; (b) tensiómetro de câmara de ar com e sem correção da temperatura, segundo período úmido.

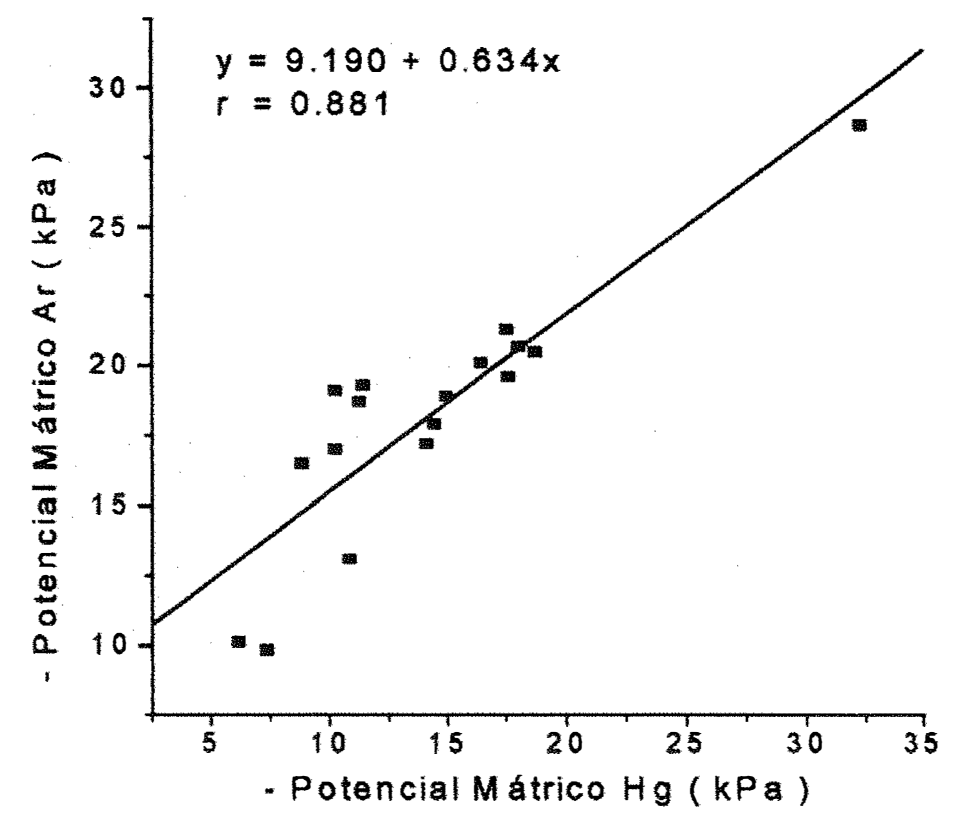

Apéndice 15 - Relaçấo entre potencial mátrico obtido por tensiômetros convencional e de camara de ar, experimento de campo, blodo $111,15 \mathrm{~cm}$, segundo período úmido. 